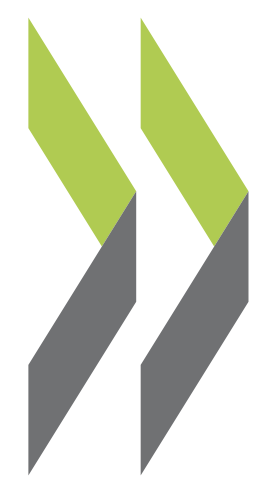

OECD Economics Department Working Papers No. 932

Fiscal Consolidation: Part 1. How Much is Needed and How to Reduce Debt to a Prudent Level?
Douglas Sutherland, Peter Hoeller, Rossana Merola 
Organisation de Coopération et de Développement Économiques

Organisation for Economic Co-operation and Development

10-Jan-2012

ECONOMICS DEPARTMENT

English - Or. English

FISCAL CONSOLIDATION

PART 1. HOW MUCH IS NEEDED AND HOW TO REDUCE DEBT TO A PRUDENT LEVEL?

ECONOMICS DEPARTMENT WORKING PAPER No. 932

by Douglas Sutherland, Peter Hoeller and Rossana Merola

All Economics Department Working Papers are available through OECD's internet website at www.oecd.org/eco/workingpapers

JT03314105

Document complet disponible sur OLIS dans son format d'origine

Complete document available on OLIS in its original format 


\section{ABSTRACT / RÉSUMÉ}

\section{Fiscal consolidation}

\section{Part 1. How much is needed and how to reduce debt to a prudent level?}

The economic and financial crisis was the catalyst for a fiscal crisis that engulfs many OECD countries. In most countries, budget deficits soared as a result of the economic slump, weaker revenues and the policy response to the crisis. Consolidating the public finances is an important challenge for many countries. Estimates of fiscal gaps suggest that substantial and sustained fiscal tightening will be needed in nearly all countries to bring debt down to prudent levels. However, given a weak global economy, implementing a large fiscal tightening could be particularly costly. Structuring consolidation packages to use instruments with low multipliers initially and enhancing the institutional framework for fiscal policy to lend greater credibility to the commitment to consolidate over time may help minimise the trade-offs with growth in the short run. In most countries there is scope to target spending programmes more effectively and eliminate distortions in taxation and re-orientate taxation to minimise distortions. Such measures, buttressed by structural reforms, such as to unsustainable pension systems, can underpin fiscal sustainability, while minimising the costs to long-run growth.

JEL Codes: H62; H63; H68

Keywords: Fiscal consolidation; fiscal gaps

*********************************************************

Consolidation budgétaire

\section{Partie 1. Quel est le degré d'assainissement nécessaire et comment ramener la dette à un niveau prudent ?}

La crise économique et financière a servi de catalyseur pour une crise budgétaire qui engloutit de nombreux pays de l'OCDE. Dans la plupart des pays, les déficits budgétaires ont fait un bond en raison du marasme économique, de la diminution des recettes et des mesures prises en réponse à la crise. Assainir les finances publiques représente un enjeu majeur pour bon nombre de pays. Sur la base d'estimations des écarts budgétaires, il semble qu'il faudra un resserrement budgétaire important et durable dans presque tous les pays pour ramener la dette à des niveaux prudents. Cependant, compte tenu de la faiblesse de l'économie mondiale, la mise en œuvre d'un vaste programme de restriction budgétaire pourrait être particulièrement coûteuse. Structurer les programmes de consolidation de façon à utiliser au départ des instruments à multiplicateurs faibles et, à terme, à améliorer le cadre institutionnel de la politique budgétaire afin de rendre plus crédible l'engagement à assainir les finances publiques pourrait aider à réduire au minimum les arbitrages avec la croissance dans le court terme. Dans la plupart des pays, il est possible de cibler plus efficacement les programmes de dépenses et d'éliminer les distorsions dans la fiscalité et de réorienter cette dernière afin de réduire au minimum les distorsions. Ces mesures, étayées par des réformes structurelles telles que la réforme des systèmes de retraite, qui ne sont plus tenables, peuvent soutenir la viabilité budgétaire tout en réduisant au minium les coûts pour la croissance à long terme.

Codes JEL : H62 ; H63 ; H68

Mots-clés : Consolidation budgétaire ; écarts budgétaire

(C) OECD (2012)

You can copy, download or print OECD content for your own use, and you can include excerpts from OECD publications, databases and multimedia products in your own documents, presentations, blogs, websites and teaching materials, provided that suitable acknowledgment of OECD as source and copyright owner is given. All requests for commercial use and translation rights should be submitted to rights@oecd.org 


\section{TABLE OF CONTENTS}

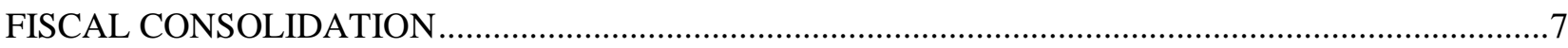

PART 1. HOW MUCH IS NEEDED AND HOW TO REDUCE DEBT TO A PRUDENT LEVEL? ..........7

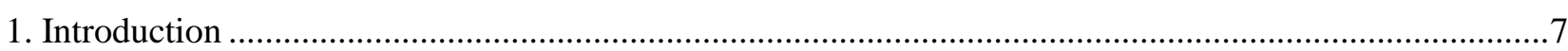

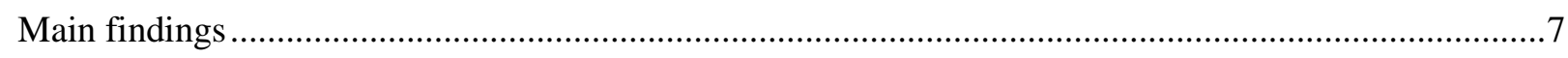

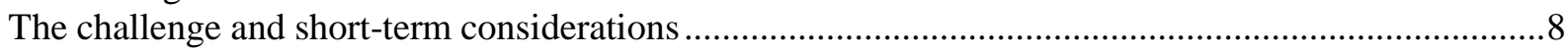

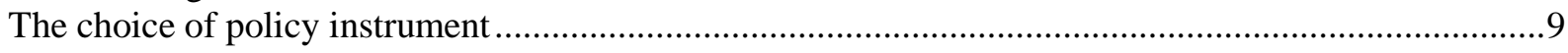

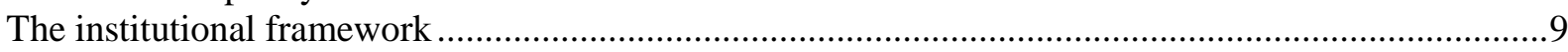

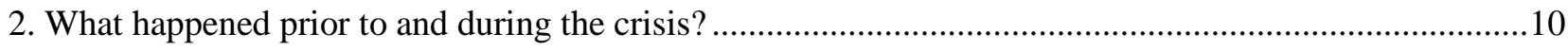

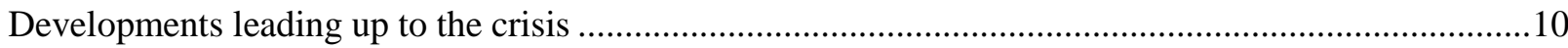

Developments during the economic and financial crisis.....................................................................11

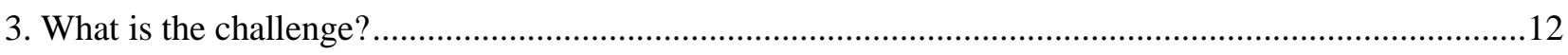

Prudent debt targets should provide a long-term anchor for fiscal policy ...........................................12

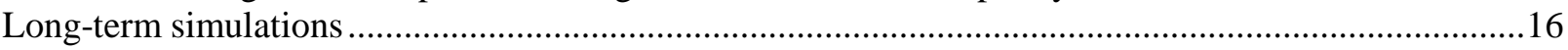

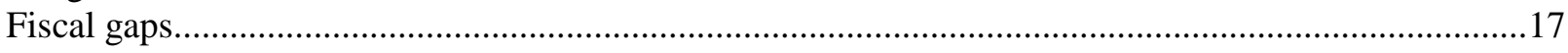

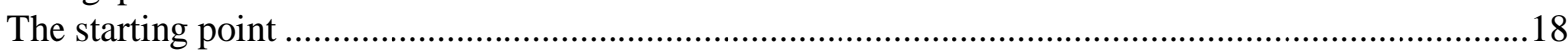

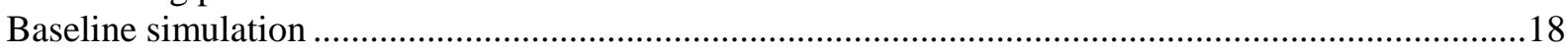

How much of a safety margin is needed to meet the baseline target? ..................................................22

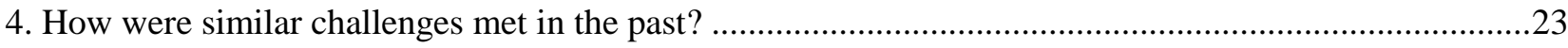

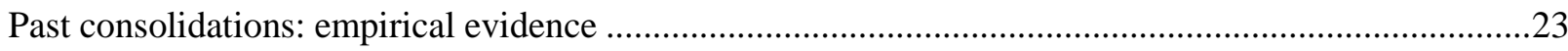

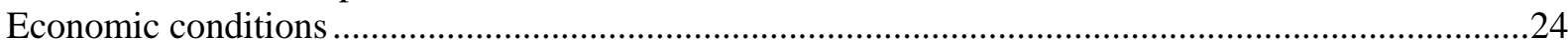

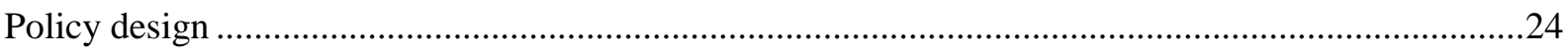

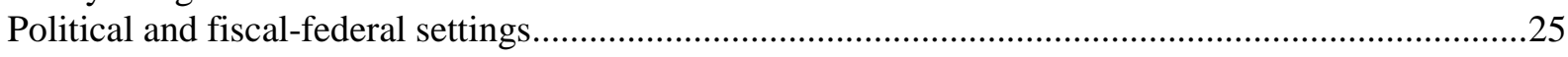

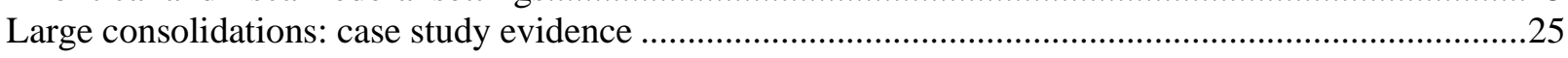

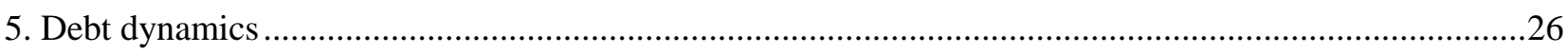

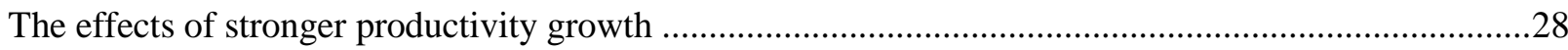

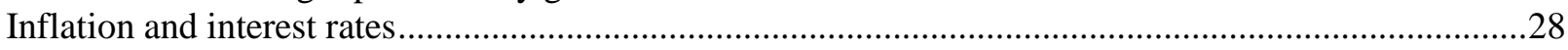

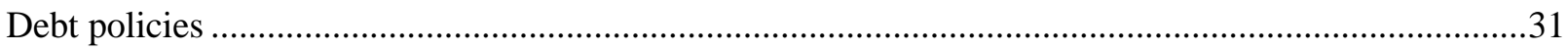

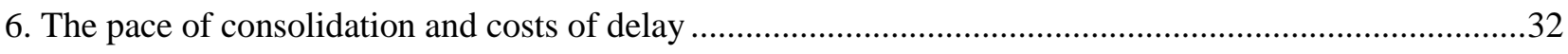

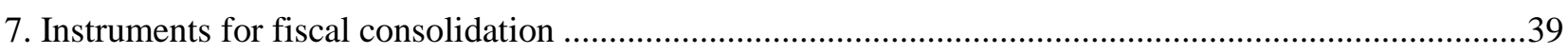

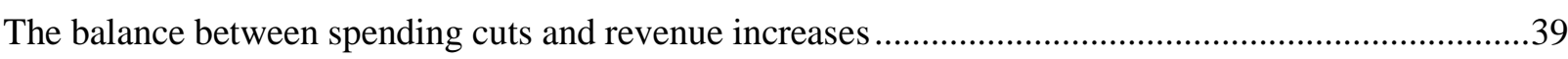

Consolidation has to be attentive to equity and other policy objectives ..................................................39

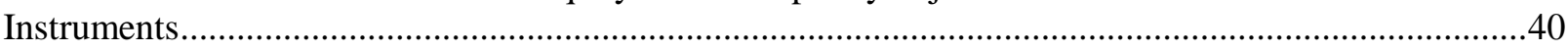

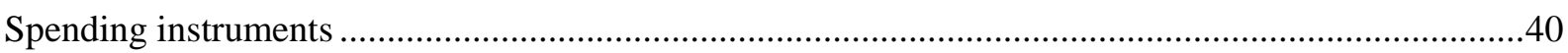

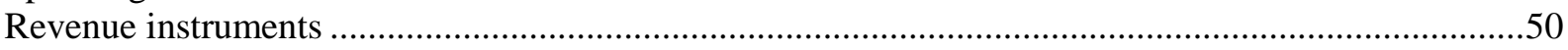

A policy matrix for growth-promoting fiscal consolidation..............................................................54 


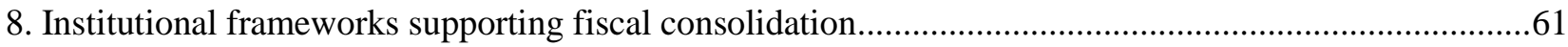

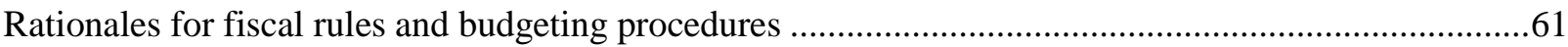

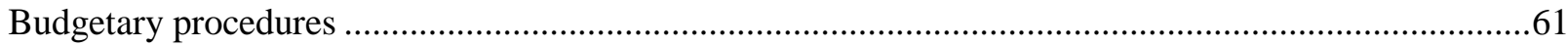

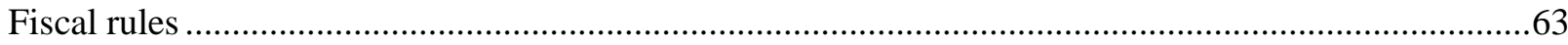

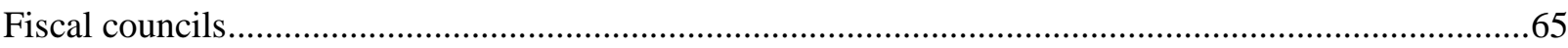

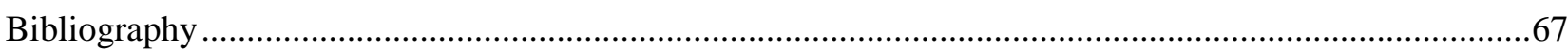

\section{Boxes}

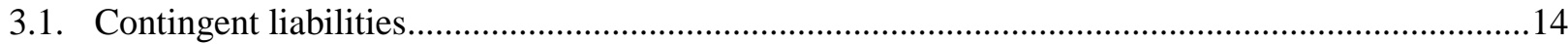

3.2. Main assumptions underlying the long-term simulations ........................................................... 17

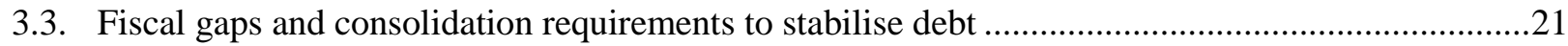

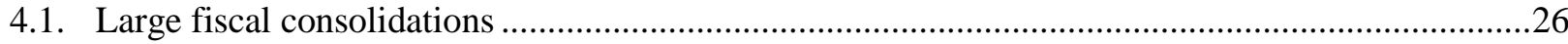

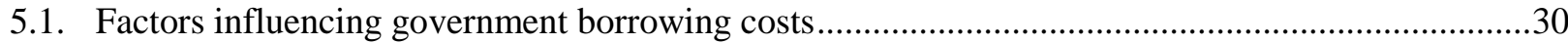

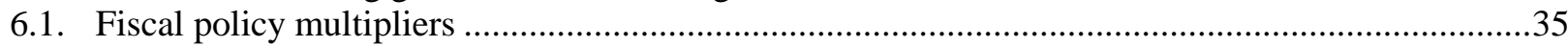

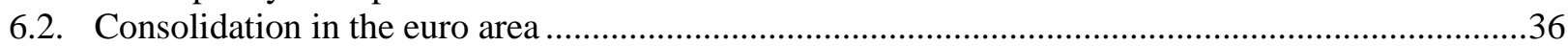

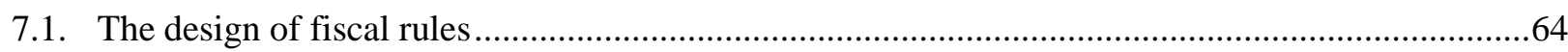

\section{Tables}

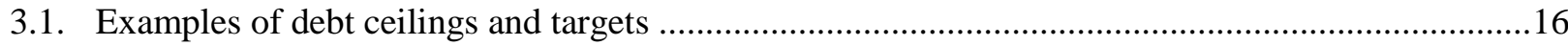

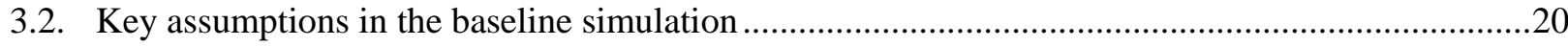

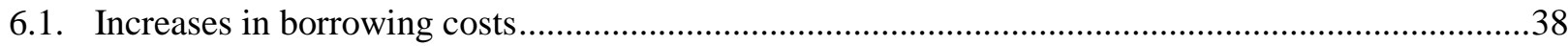

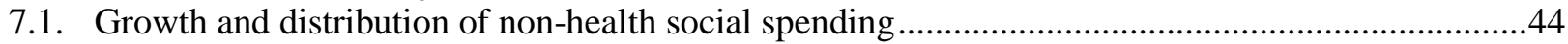

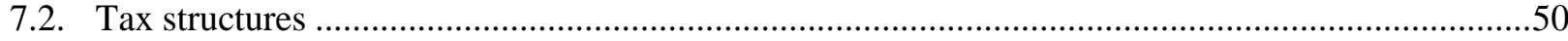

7.3. Trade-offs and complementarities between fiscal consolidation instruments and growth ...............56

7.4. Quantifying the contribution of various policy instruments to fiscal consolidation.........................59

\section{Figures}

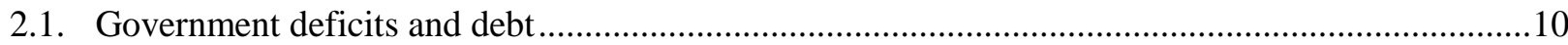

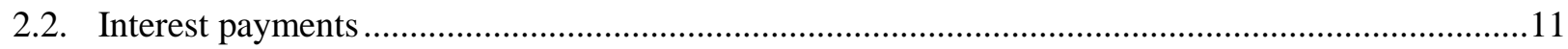

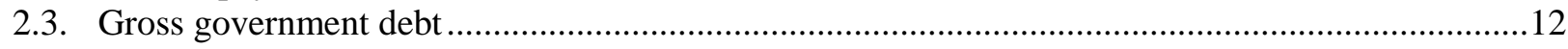

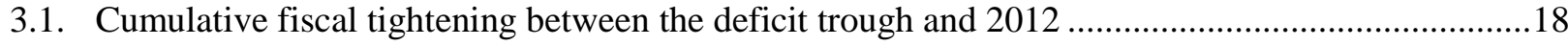

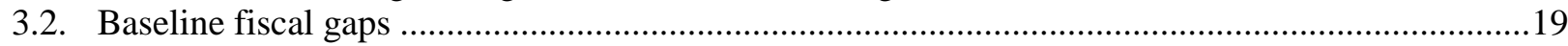

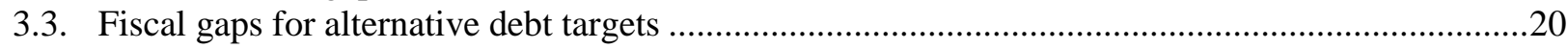

3.4. Relation between fiscal gaps and consolidation requirements ..................................................22

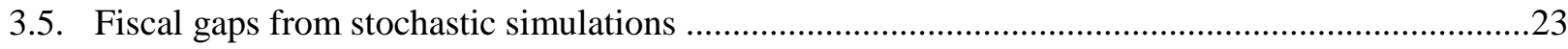

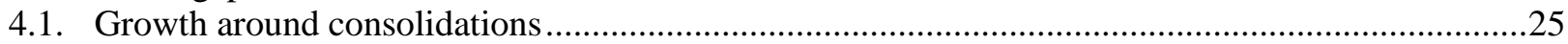

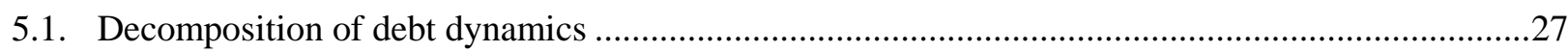

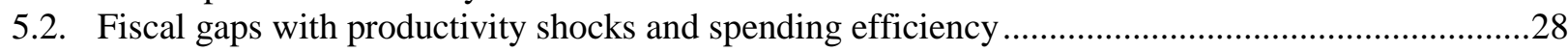

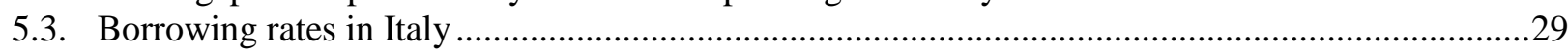

5.4. Non-consolidated private financial liabilities, excluding shares and other equity ............................31

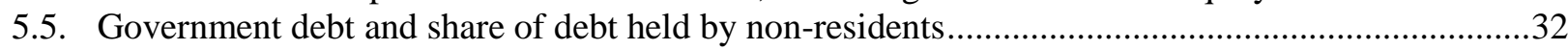

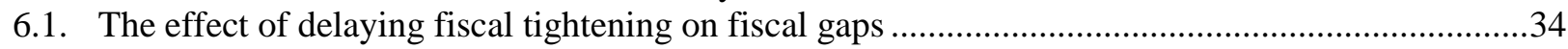

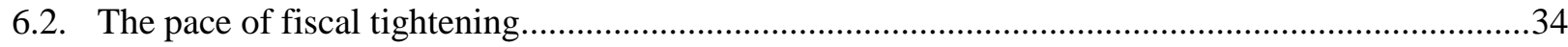

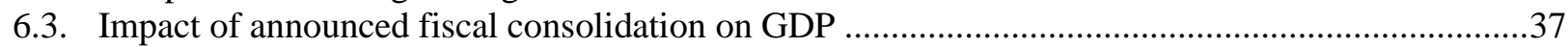




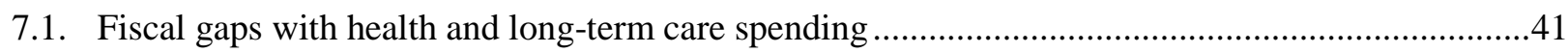

7.2. Budgetary savings from improved efficiency in health care systems .......................................42

7.3. Public and private spending on educational institutions ................................................................42

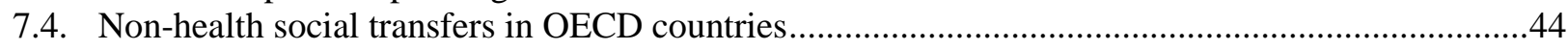

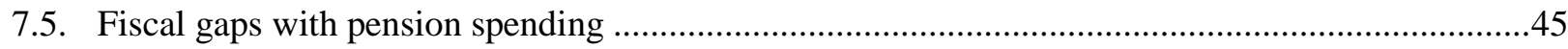

7.6. Debt evolution with pension, health and long-term care spending ..............................................46

7.7. The effects of delayed retirement on fiscal gaps .........................................................................4

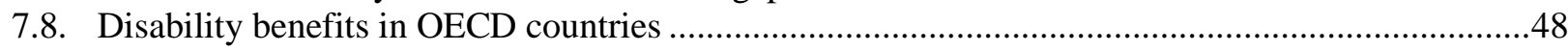

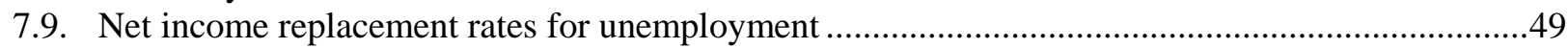

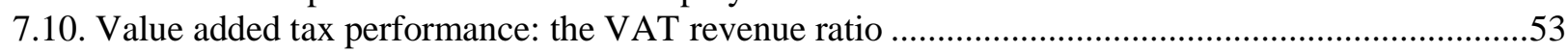

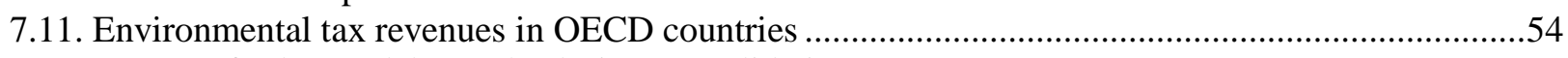

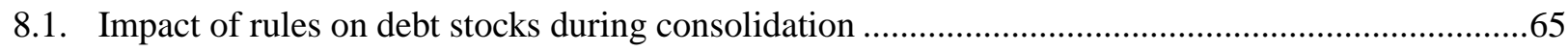

This document and any map included herein are without prejudice to the status of or sovereignty over any territory, to the delimitation of international frontiers and boundaries and to the name of any territory, city or area.

The statistical data for Israel are supplied by and under the responsibility of the relevant Israeli authorities. The use of such data by the OECD is without prejudice to the status of the Golan Heights, East Jerusalem and Israeli settlements in the West Bank under the terms of international law. 
ECO/WKP(2012)9 
ECO/WKP(2012)9

\title{
FISCAL CONSOLIDATION
}

\section{PART 1. HOW MUCH IS NEEDED AND HOW TO REDUCE DEBT TO A PRUDENT LEVEL?}

\author{
by Douglas Sutherland, Peter Hoeller and Rossana Merola ${ }^{1}$
}

\section{Introduction and main findings}

The economic and financial crisis was the catalyst for a fiscal crisis that engulfs many OECD countries. In most countries, budget deficits soared as a result of the economic slump, weaker revenues, partly due to the effect of declining asset prices, and the policy response to the crisis. Debt is likely to reach unprecedented levels in 2011, with government gross financial liabilities exceeding $100 \%$ of GDP for the OECD on average. High debt levels imply that stabilising debt can only be a short-term goal of fiscal policy. A sustained effort to reduce debt to prudent levels is required to create sufficient fiscal space to meet future challenges. This implies an opportunity for a fundamental reorientation of fiscal policy in many countries.

Following a summary of the main findings in the remainder of this section, the next section provides a brief review of deficit and debt developments before and during the crisis. The third section argues that country-specific debt targets should provide a long-term anchor for fiscal policy and that this will help in calibrating medium-term fiscal targets. This section also includes calculations of the necessary fiscal adjustment to reach various long-term debt targets. The fourth section discusses how consolidations have been implemented in the past, drawing on econometric and case study evidence. The fifth section assesses how growth and interest rate dynamics can assist or undermine consolidation efforts. The sixth section discusses the pace of consolidation and the trade-offs with short-term stabilisation. In the seventh section a large number of spending and revenue areas that hold promise of contributing to fiscal consolidation are reviewed, both through their direct budgetary impacts and indirectly through favourable effects on growth. The last section discusses budgetary procedures, fiscal rules and institutions, which may assist fiscal consolidation.

\section{Main findings}

The main findings can be divided into those that concern the short and long-term policy considerations, the choice of policy instruments and institutional frameworks that underpin fiscal policy.

1. The authors are members of the Economics Department of the OECD. This is the main paper for the OECD's project on Fiscal Consolidation. The paper is a revised version of a document prepared for a meeting of Working Party No. 1 of the OECD Economic Policy Committee held in October 2011. The authors would like to thank the participants of the meeting, as well as Jørgen Elmeskov, Jean-Luc Schneider, other members of the Economics Department and Bob Hagemann for valuable comments and suggestions and also Susan Gascard for excellent editorial support. The other papers from the project are Barrell et al. (2012), Hagemann (2012), Merola and Sutherland (2012), Molnar (2012) and Blöchliger et al. (2012). 


\section{The challenge and short-term considerations}

- In the wake of the recent crisis, many countries face enormous fiscal challenges just to stabilise debt-to-GDP ratios, which would remain at clearly unsustainable levels. Some countries Greece, Iceland, Ireland, Portugal and Spain - have started fiscal consolidations of between 5\% and $12 \%$ of GDP, which are large by historical comparison.

- Fiscal consolidation is not only about stabilising debt, but also needs to consider the appropriate debt objective for the long term. Due to elevated debt levels, many countries have very little fiscal space to address on-going economic weakness. In this context, the longer-term aim of fiscal consolidation should be to bring debt down to prudent levels. A debt target would provide a longterm anchor for fiscal policy and may prevent slippage, which could counter the past tendency of debt levels to ratchet up during recessions.

- Fiscal gap calculations, which show the immediate and permanent change in the underlying primary balance that is needed to hit a debt target at a certain date, can illustrate the challenges ahead. Taking current consolidation plans to 2012 as the jump-off point and aiming at a 50\% debt-to-GDP ratio by mid-century suggest that many countries face a daunting task. In the absence of reforms to spending programmes, many countries may have to embark on an additional immediate and permanent fiscal tightening. In Japan, the required fiscal consolidation could approach $10 \%$ of GDP, while in New Zealand, the United Kingdom and the United States the required fiscal tightening would exceed 5\% of GDP.

- These fiscal gap calculations use an arbitrary target and end point of 2050 and alternative targets, time frames and whether projected increases of spending increases on pensions and health care are included could alter the scale of the challenge. For example, without reform to entitlement programmes, many countries face mounting pressures on public finances beyond 2050. Addressing unsustainable pension systems can make a large difference in how much fiscal tightening is needed, with projected pension spending responsible for one-fifth of the overall tightening needed on average. Including spending on health care could raise fiscal gaps to as much as $5 \%$ of GDP on average.

- The assumption of an immediate and permanent adjustment is unlikely to be met, except for small adjustments. In this light, assuming fiscal consolidation will be introduced more slowly, the fiscal gap calculations provide a lower bound of the needed adjustment. Delaying fiscal tightening, jumps in borrowing costs and additional fiscal shocks, would raise the degree of tightening needed to bring debt down and argues for building a safety margin into the long-run debt target and where possible in the short-term consolidation effort.

- Given the current state of the economy, implementing a large fiscal tightening could be particularly costly. For example, simulations of announced fiscal consolidation packages reveal that the largest consolidations could reduce GDP by around 6\% relative to the baseline. However, in some cases not pursuing fiscal action could have even starker consequences. The countries most under pressure from financial markets have thus little option, though a credible consolidation strategy and institutional framework may offer greater leeway in the short run.

- For most countries a sustained period of consolidation will be needed. Structuring the consolidation package to use instruments with low multipliers initially may help minimise the trade-offs with growth in the short run. 
- While higher growth and lower interest rates could help the consolidation process, most countries will need to rely principally on tightening the underlying primary balance.

\section{The choice of policy instrument}

- In designing consolidation packages, fiscal policy makers face choices along a number of dimensions, such as the trade-off with short-term stabilisation, longer-term growth, intergenerational balance and distributional aims. Previous large consolidations have relied on both spending and revenue measures and addressing the current challenge will likely need a mix of measures in most countries.

- Given the scale of ageing and other spending pressures, reforms to entitlement programmes need to be an important part of any longer-term sustainability strategy and could make a marked impact in reducing the amount of fiscal tightening to meet long-term debt objectives. Pre-saving makes sense for transitory demographic shocks but not for permanent ones such as increasing longevity. The coming demographic transition dictates that such reforms should be undertaken quickly, particularly given the long phase-in such reforms typically require. Reforms to pension systems, which delay retirement and increase labour force participation can significantly reduce long-run budget pressures.

- Non-ageing related spending pressure, principally from health and long-term care will continue to mount. The optimal level of such spending is unsure and spending may need to rise. On average across the OECD, if the long-term objective is to bring debt down to 50\% of GDP, making room for health and long-term care spending may require permanent and immediate fiscal tightening of up to $2 \%$ of GDP. However, efficiency gains in public spending could yield significant savings in the longer term.

- There is scope to broaden tax bases by eliminating tax expenditures. These can be costly, with individual large items often accounting for $1 \%$ of GDP and total tax expenditures worth several percentage points of GDP.

- When tax revenues need to rise then adverse effects on growth need to be taken into account. Environmental taxes, user fees for government services, taxes on immovable property and welldesigned financial sector levies offer the potential to support fiscal consolidation while minimising distortions.

- The distributional consequences of fiscal consolidation are best addressed by considering the tax and benefit system as a whole, judging whether the overall impact on income distribution can be considered fair. There may be scope to target transfers better to meet distributional aims, though this creates a trade-off between lower spending and adverse incentive effects due to higher effective marginal tax rates during the benefit withdrawal phase. Flanking measures may be required to mitigate the distributional consequences of some reforms.

\section{The institutional framework}

- Fiscal institutions and rules may be helpful in buttressing credibility, particularly for countries facing strong headwinds from financial markets. In the longer run, improved institutional frameworks can help ensure that fiscal policy stays on track to bring debt down. 
- Combinations of fiscal rules are likely to be helpful and appropriately mandated (independent) fiscal councils or similar institutions may help raise transparency and help hold governments accountable for meeting their long-term sustainability goals.

- The introduction of fiscal rules and institutions is often relatively recent and there is still limited evidence of their full effects on policy. They may allow the path of consolidation to vary in the short run, but they are unlikely to generate a sufficient degree of credibility on their own. As such, while commitment technologies can underpin fiscal consolidation, in the absence of sustained political will, they are unlikely to be sufficient on their own.

\section{What happened prior to and during the crisis?}

During the economic and financial crisis, fiscal positions across the OECD deteriorated severely, although a few countries have emerged relatively unscathed. Most, though not all, countries are now in consolidation mode. This section provides a brief review of the deficit and debt developments before and during the crisis.

\section{Developments leading up to the crisis}

Debt levels in the OECD have tended to trend upwards since the early 1970s. The current surge in debt is the third such episode since the early 1970s (Figure 2.1). Following the earlier episodes, fiscal consolidation in many countries did not reverse the rise in debt sufficiently to bring it back down to a prudent level. As a result, following the recent crisis, debt in some countries has risen to levels only seen after major wars.

Figure 2.1. Government deficits and debt

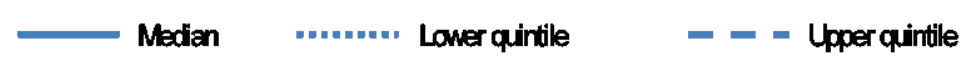

\section{Pand A Net lending}

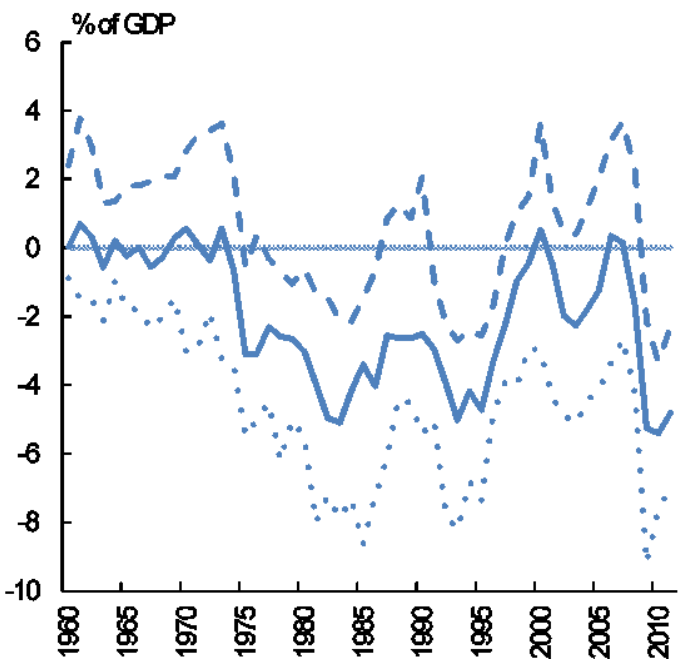

Panel B. Gross finencial liabilities

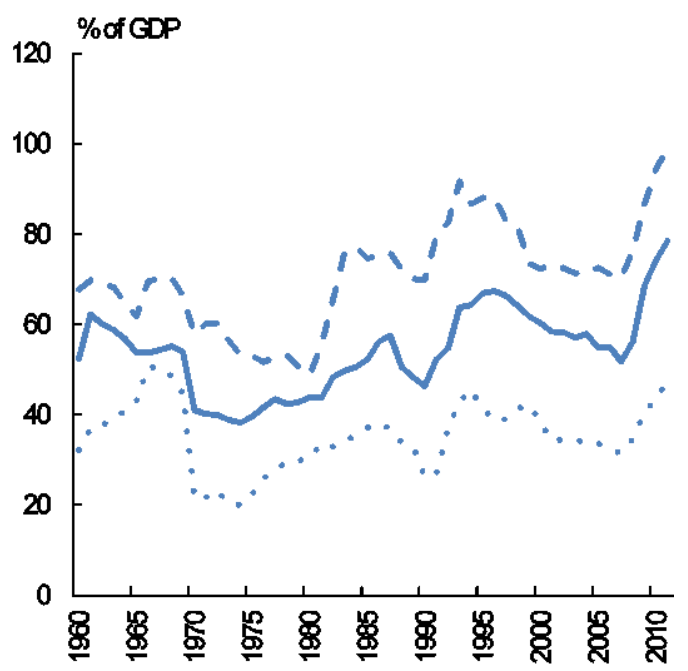

Note: The medians, upper and lower quintiles are for the observation at that date and thus the median country differs over time and across the two panels.

Source: OECD Economic Outlook 89 Database. 
Many countries had been insufficiently ambitious in bringing debt levels down after the relatively mild recession in the early 2000s. Indeed, during the upswing before the recent crisis, cyclically-adjusted balances were not reduced much in a number of countries, notably Greece, the United Kingdom and the United States. In some cases, declines in revenue shares during the expansion suggest that governments were engaging in a pro-cyclical easing of fiscal policy. ${ }^{2}$ The impact of lower interest rates and in some cases lower debt on debt servicing costs during the "great moderation" era (Figure 2.2) and the apparent strength of revenues seduced some governments into cutting taxes and relaxing control over spending. Indeed, new estimates of cyclically-adjusted budget balances that take account of asset price effects on revenues suggest significantly weaker balances in a number of countries (Price and Dang, 2011). As such, when fiscal positions appeared to improve before the financial crisis, they were often too flattering. And in retrospect, fiscal positions were insufficiently robust given the scale of the contingent liabilities that governments had to assume during the crisis.

Figure 2.2. Interest payments

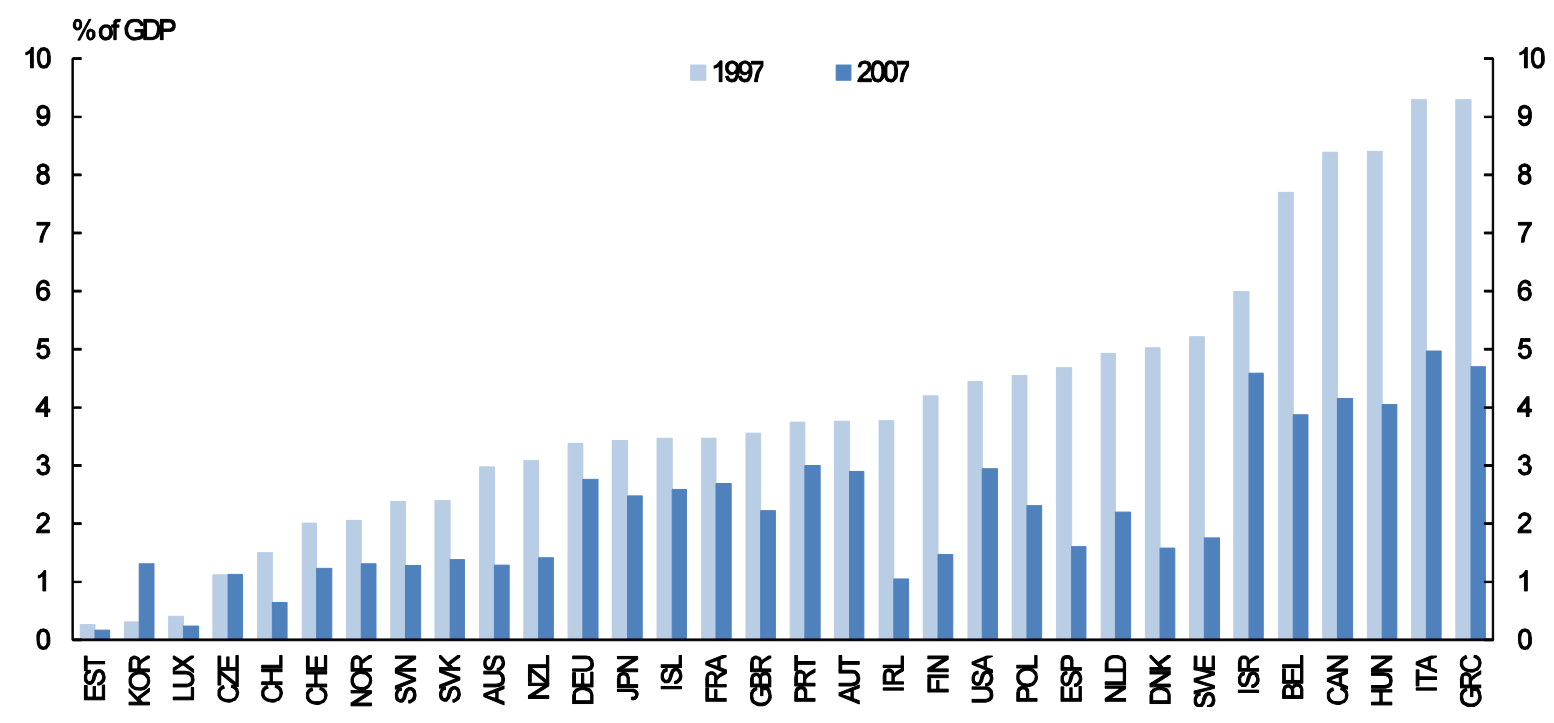

Source: OECD Economic Outlook 89 Database.

\section{Developments during the economic and financial crisis}

What sets the crisis apart is how widespread and how rapid the build up of debt has been, making the need for fiscal consolidation pressing for most OECD countries. In part this has been a consequence of the severity of the crisis, but many countries were also poorly prepared to face a large, adverse shock (Sutherland et al., 2010). The automatic stabilisers played a role with spending on unemployment benefits surging and tax revenues evaporating. Tax revenues were further dented by asset price movements, which had boosted revenues in the pre-crisis period. Spending further jumped due to support packages and the scale of the contingent liabilities governments had to assume. Soaring deficits combined with lower nominal GDP growth, pushed up debt ratios in most countries (Figure 2.3). For the OECD as a whole, government gross financial liabilities are expected to rise to unprecedented levels, exceeding 100\% of GDP for the first time in 2011. In Japan, this ratio will rise to over 200\% of GDP. Even in some low-debt

2. Empirical evidence suggests that while fiscal policy is generally counter-cyclical during recessions it is at best a-cyclical, but often pro-cyclical, during upswings, particularly towards the end of the expansion (Égert, 2010). 
countries debt increased quite strongly. Only Norway and Switzerland have bucked the trend, reducing debt levels.

Figure 2.3. Government gross financial liabilities

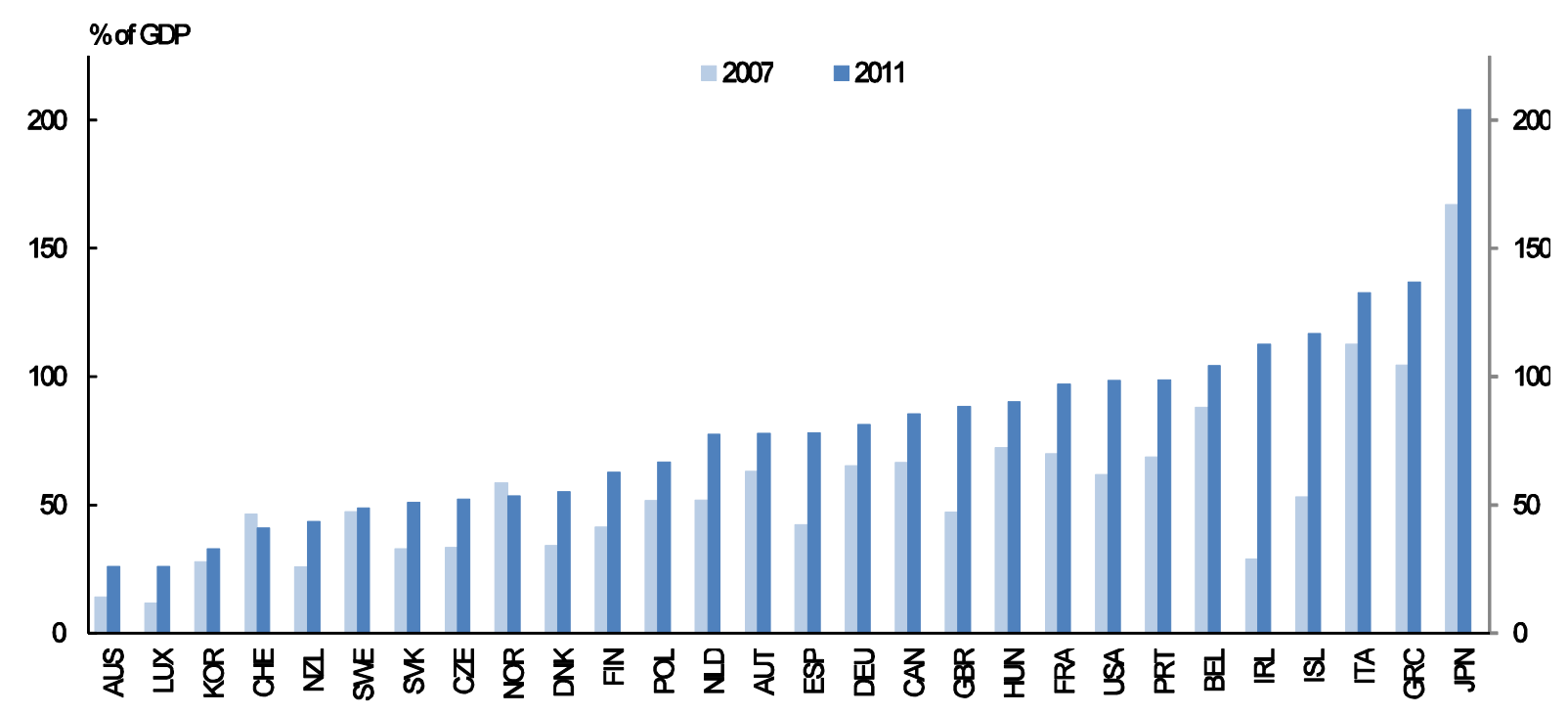

Source: OECD Economic Outlook 89 Database.

\section{What is the challenge?}

This section argues first that country-specific debt objectives around which variations can take place should provide a useful long-term anchor for fiscal policy and that this will help inform the decisions concerning the scale of consolidation. This is followed by the presentation of long-term simulations that are used to derive fiscal gaps, or the needed tightening in underlying primary balances, to reach various debt targets. It also provides sensitivity analysis.

\section{Prudent debt targets should provide a long-term anchor for fiscal policy}

Theory suggests various channels through which government debt can affect economic activity and welfare in the long run, but without reaching any firm conclusion as to the desirable debt level. Determining the optimal debt level empirically is thus not straightforward.

- Lower public saving, which is not matched by higher private saving, will raise the interest rate and depress investment and thereby output and income in a closed economy. In the open economy case, higher interest rates will attract capital inflows and create pressure for the exchange rate to appreciate, which will keep up domestic investment, but foreigners accrue the return on their investment, lowering national income relative to output. ${ }^{3}$

- While the debt service payments themselves may be merely a transfer among members of society, the taxes needed to service the debt generate a deadweight loss, which rises more than

3. CBO (2011a) provides a long-term scenario, where a $\$ 1$ increase in the government deficit would be offset by a rise in savings by only 40 cents. The sharp rise in projected debt due to ageing implies that real GDP per capita could be $17 \%$ lower, with lower output and higher interest rates due to crowding out leading to even higher debt. 
proportionally with tax rates. One approach to analysing optimal debt levels suggests that due to deadweight losses, tax rates should be held constant over time and government debt should be the shock absorber (Barro, 1979; Lucas and Stokey, 1983; Kirsanov and Wren-Lewis, 2007). If major events, like wars or banking crisis, lead to a large jump in debt, the optimal tax rate has to be reset. This implies that debt is an instrument rather than a target and hence rigid targets could produce sub-optimal outcomes.

- On the positive side, public debt can help overcome imperfections in financial market intermediation (Woodford, 1990). By providing liquid assets, public debt increases the flexibility of the private sector in responding to variations in income and spending opportunities. In this model, higher public debt could lead to higher saving and investment, as otherwise investors would have to shun productive investment opportunities, if they are liquidity constrained.

The net balance of these opposing arguments will depend on the initial debt level, the debt trajectory and various model parameters. Calibrating a US model and including a negative crowding out effect as well as taxes that have adverse incentive and wealth effects and a positive liquidity effect, Aiyagari and McGrattan (1998) found that the optimal debt/GDP ratio is close to 2/3, which is near the post-war average debt/GDP ratio for the US economy.

While it is difficult to deduct optimal debt levels from first principles, there are several reasons, grounded in empirical work, why high debt levels are problematic:

- Fiscal policy, individuals and businesses appear to act differently depending on the debt level. High debt levels appear to induce fiscal policy to become pro-cyclical and public-private saving offsets to become larger. ${ }^{4}$ Furthermore, there is some evidence of non-linearities in interest rates related to the level of debt. In one study, Égert (2010) found for the G7 (excluding Japan) that the long-term government bond interest rate spread over short-term rates rises when public debt exceeds three quarters of GDP. Below this threshold, changes in public debt did not have a statistically significant effect.

- High public debt levels may have adverse effects on growth and inflation. ${ }^{5}$ For example, Reinhart and Rogoff (2010) identified various thresholds: $i$ ) for both developed and developing countries growth rates in countries where the public debt to GDP ratio exceeds $90 \%$ are about $1 \%$ lower than in the less indebted countries (Cecchetti et al., 2011 find a similar threshold effect); ii) in emerging markets, inflation and public debt levels are strongly correlated. In a similar vein, Caner et al. (2010) found a threshold effect on growth rates at 77\% of GDP for a large sample of countries, with again the threshold being lower for emerging markets; Kumar and Woo (2010) found that a 10 percentage point increase in debt reduces annual real per capita GDP growth by 0.2 percentage points per year, with the effect being smaller for advanced economies and some evidence for non-linearity beyond a debt/GDP ratio of $90 \%$ of GDP.

These considerations argue in favour of keeping debt below a threshold of around 75\% of GDP. Debt targets would provide an anchor for fiscal policy to bring debt under control, countering the upward trend in debt levels experienced in many OECD countries. To the extent that macroeconomic volatility is likely to be higher than during the great moderation era, low prudent debt targets would create more fiscal space

4. The larger private saving offsets at high debt levels imply lower interest rates, while risk premia at high debt levels imply higher interest rates. As underlying interest rates are largely set in the international financial markets, the net outcome is likely to be high interest rates for highly indebted countries. For instance, since the sovereign debt crisis has started, the US and German long-term bond yields have become very low, but those in many highly-indebted countries have shot up.

5. Such findings do not take into account the possible endogeneity of the relationship. 
to cope with future shocks. The debt targets should take at least part of the contingent liabilities, such as the cost of banking crises, into account (Box 3.1. ${ }^{6}$ While the recent financial market crisis may have a smaller direct fiscal impact than early estimates suggested, it is still large for the most exposed countries. IMF (2010) estimates the net direct budgetary costs of supporting financial institutions at $2.8 \%$ of GDP for the advanced economies, but the total impact due to the sharp recession and lower growth in potential output is much larger. ${ }^{7}$ Prudent debt targets should thus be considerably lower than $75 \%$ of GDP and also consider the risks associated with the maturity of the debt and liquidity risks due to foreign holdings of debt.

\section{Box 3.1. Contingent liabilities}

Governments provide explicit or implicit insurance coverage for a number of contingencies. ${ }^{1}$ These liabilities include guarantees for state insurance schemes covering property and casualty losses from terrorism, coverage against crop failure or losses of deposit insurance schemes. Moreover, private insurance for nuclear power plant disasters is limited and governments are likely to assume the rest of eventual costs. They also cover state guarantees for various types of loans (for instance, for mortgages, student or small business loans). Implicit contingent liabilities include the cost of bailing out failing banks or other enterprises, of sub-national governments or off-budget state agencies. These are just some examples and the number of possible claims is large.

Government budgets typically recognise such losses when the government makes payments to beneficiaries. However, budgets tend to anticipate a "normal" amount of spending for explicit contingent liabilities by setting aside funds in a contingency reserve and disaster mitigation policies help lowering the cost of natural disasters. As the magnitude and timing of such contingencies are difficult to predict, the reserve could be too high or too small in any budget year. The US Congressional Budget Office provides an estimate of contingent liabilities, but only for losses that hit with some reasonable probability. It estimated that net contingent liabilities for federal insurance programmes (losses not offset by premiums) totalled USD 93 billion in 2003 (CBO, 2004). In the United Kingdom, recent estimates of quantifiable contingent liabilities amounted to GBP 206.8 billion (12\% of GDP) while remote contingent liabilities which are too uncertain to record under international accounting standards - amounted to an additional GBP 653 billion (36\% of GDP) in 2010, mainly in the form of guarantees and indemnities (HM Treasury, 2011).

Most of the programmes covering explicit contingent liabilities cover losses that are at least partly insured. When the losses occur, they tend to be of a manageable size, though they can also be large. Implicit contingent liabilities often pose the greatest fiscal risk to government budgets. Events triggering such liabilities are highly uncertain, the value at risk difficult to evaluate and the extent of government involvement difficult to assess ex ante. The bail-outs of financial institutions are a good example of infrequent implicit contingent liabilities, which can sometimes be very costly. The direct fiscal costs of past bail-outs has sometimes reached more than $10 \%$ of GDP, for instance, in Finland and Korea, and including the fiscal costs of lost output they were close to or higher than $20 \%$ of GDP in Finland, Japan, Korea, Norway and the United States (OECD, 2008). Over time, the scale of fiscal costs can fall as the government earns a return on its investment in the financial sector.

1. Direct liabilities can also be explicit or implicit. Explicit ones include the repayment of sovereign debt or repayment of nonperforming loans guaranteed by the state. Implicit ones include future public pension payments, though their size is uncertain as benefit levels may change in the future.

6. There have also been episodes in the past, where governments have taken over large amounts of debt, such as the debt of the Treuhandanstalt in Germany.

7. Focusing on countries that experienced a systemic crisis between 2007 and 2009, Laeven and Valencia (2010) show the average increase in public debt to be $24 \%$ of GDP and cumulated output losses to be $26 \%$ of potential GDP. These estimates are not significantly different from the effects of earlier systemic crises. 
Various choices have to be made in setting a debt target:

- The target can be based on either gross or net debt/financial liabilities. Gross financial liabilities are a visible headline indicator and typically the measure used in empirical analysis. ${ }^{8}$ Net financial liabilities are in principle more appropriate when considering long-term sustainability, though government net worth, which also takes into account non-financial assets (the public capital stock), may be the appropriate indicator when also considering inter-generational issues. However, there are serious problems due to lack of comparability across countries, particularly when valuing government non-financial assets. Furthermore, government assets may not be easily used to offset liabilities, at least in the short term. For example, it may not be advisable to privatise public enterprises operating in sectors with significant market failures or when financial markets could not easily absorb large asset sales. There may also be asymmetries across levels of government and with social security funds between the holding of assets and liabilities.

- The scope of the public sector can vary. For example, the debt target may affect only the central government, general government or an even wider definition, including for instance, public enterprises. The choice can make a sizeable difference. In the United Kingdom, recent whole of government accounts estimated net liabilities to be $84.5 \%$ of GDP in 2009-10, whereas the national accounts net liabilities measure was $52.8 \%$ of GDP (HM Treasury, 2011).

- If the focus is on servicing debt, then the measure of debt should correspond to gross interest bearing liabilities but if it is the present value budget constraint, all liabilities should be included.

- The target should address the effect of ageing on entitlement spending. The appropriate degree of consolidation will need to take into account the impact of ageing-related spending. Ageingrelated spending pressures stem from two factors. First, spending ramps up with the demographic transition as the "baby boomers" move into retirement. As this transition is either already happening or is imminent, the policy options are limited. In this light, the increased spending may need to be absorbed and adds to the consolidation requirement. A second ageing problem stems from rising longevity. In this case, the appropriate response is to reform pension and other benefit systems, such as long-term care, rather than to attempt to pre-save to finance the rising ageingrelated spending. ${ }^{9}$

- Finally, the target should also consider inter-generational fairness. Pay-as-you-go pension systems present an obvious example of a transfer of resources between generations. More generally, "excessive" deficits can transfer liabilities to future generations. In other cases, investment can create assets which will be enjoyed by future generations. As such, the degree of

8. Gross financial liabilities and gross debt are closely related measures. In this paper the emphasis is given to gross financial liabilities which are available for all countries, whereas gross debt is available for European Union members. Gross debt according to the Maastricht criterion differs from the SNA based general government gross financial liabilities concept of the OECD in essentially two respects. First, gross debt according to the Maastricht criterion does not include, in the terminology of the SNA, trade credits and advances. Second, there is a difference in valuation methodology in that government bonds are to be valued at nominal values according to the Maastricht definition, but at market value or at issue price plus accrued interest according to SNA rules.

9. In some circumstances pre-funding of entitlements will lead to greater certainty about the future level of transfers. Pre-funding can reduce the needed hike in future tax rates, which may have to rise sharply, with particularly adverse growth and welfare consequences if governments find it difficult to suddenly change spending. However, particularly in the case of health and long-term care, future spending is very uncertain. In this context, pre-funding as a policy option stands a considerable risk of delaying the necessary reforms to entitlements, sowing the seeds for future fiscal problems. 
consolidation will need to consider the source of the transfer between generations and how much of a burden it is fair to pass onto future generations.

Many countries have set debt ceilings or targets (Table 3.1). New Zealand, for instance, aims at a prudent debt ratio of no more than 20\% of GDP, the United Kingdom set a $40 \%$ of GDP public sector net debt ceiling prior to the crisis, Poland aims to keep public state debt below 50\% of GDP with thresholds triggering remedial action at $50 \%, 55 \%$ and $60 \%$ of GDP combined with a constitutional ceiling of $60 \%$ of GDP and Hungary recently set a ceiling of $50 \%$ of GDP. The European Union has set a $60 \%$ of GDP gross debt ceiling for its member countries. ${ }^{10}$ EU countries should also respect the deficit target enshrined in the Stability and Growth Pact, which in steady state will ensure convergence towards an implicit debt target. Spain has recently embedded EU fiscal requirements in its constitution. In other cases, coalition agreements set debt targets for the life of a parliament.

Table 3.1. Examples of debt ceilings and targets

\begin{tabular}{|c|c|c|c|}
\hline & Target & Year & Basis \\
\hline Australia & Medium term improvement of net financial worth & 1998 & Fiscal Responsibility Law \\
\hline Canada & $\begin{array}{l}\text { Keeping debt to GDP ratio on a permanent } \\
\text { downward track }\end{array}$ & 1998 & Fiscal Responsibility Law \\
\hline Denmark & Ensure stable net-debt to GDP ratio over longer term & 2007 & Coalition agreement \\
\hline European Union & Gross government debt below $60 \%$ of GDP & 1997 & $\begin{array}{l}\text { Stability and Growth Pact (medium } \\
\text { term budgetary objectives) }\end{array}$ \\
\hline Hungary & Below $50 \%$ of GDP & 2011 & Constitution \\
\hline Netherlands & Reduce national debt to $40 \%$ of GDP & 2007 & Coalition agreement \\
\hline New Zealand & Ensure prudent debt level & 1994 & Public Finance Act \\
\hline Poland & $\begin{array}{l}50-55-60 \% \text { of GDP thresholds for public state debt } \\
\text { with a constitutional ceiling of } 60 \% \text { of GDP }\end{array}$ & 1997 & Public Finance Act and Constitution \\
\hline Spain & Same as European Union & 2011 & Constitution \\
\hline United Kingdom & Net debt less than $40 \%$ of GDP over the cycle & 1997 & Code for Fiscal Stability* \\
\hline United States & $\begin{array}{l}\text { Congress sets limit to total amount of bonds that } \\
\text { can be issued }\end{array}$ & 1917 & Second Liberty Bond Act \\
\hline
\end{tabular}

* No longer applies.

\section{Long-term simulations}

This section considers the scale of consolidation requirements using highly stylised long-run simulations to 2050. The underlying model is deliberately simple (Merola and Sutherland, 2012). It builds on the assumptions underlying the Economic Outlook medium-term baseline on potential output growth, output gaps, interest and inflation rates until 2025. Between 2025 and 2050, GDP growth is determined by the growth rate of potential, which is driven by demographic developments and assumptions about productivity growth. The fiscal side of the model assumes that revenues adjusted for the cycle remain a constant share of GDP and, in the baseline, primary spending is also a constant share of GDP. The main assumptions are summarised in Box 3.2.

10. Countries with a debt above $60 \%$ of GDP originally had to ensure that the ratio declined at a "satisfactory pace". The target was imposed to avoid negative spillover effects of highly indebted countries on the other countries in monetary union and to facilitate the European Central Bank's pursuit of its price stability mandate. However, as no definition of "satisfactory pace" was provided, a number of EU member countries maintained high debt ratios, while still complying with the Stability and Growth Pact rules. A recent reform includes the requirement to reduce debt by $1 / 20^{\text {th }}$ of the difference between the debt/GDP ratio and the $60 \%$ Maastricht debt limit. 


\section{Box 3.2. Main assumptions underlying the long-term simulations}

For any long-run fiscal projections, GDP growth, interest rates and inflation together with the fiscal assumptions determine long-run sustainability. In the country models the main assumptions are as follows:

- $\quad$ GDP growth in the long term is driven by potential output. One of the main components of potential output that is varying over time is working age population growth, which is based on cohort data from long-term demographic projections. GDP growth is then determined by participation rates and employment and labour productivity growth. The latter is assumed to converge to $1.75 \%$ by 2035 at the latest. The simulations ignore possible impacts of fiscal policy and debt developments on output.

- Interest rates on government borrowing are partly determined by monetary policy. The return of output to potential is accompanied by a normalisation of interest rates, such that the risk-free rate is at its estimated natural rate by 2025 . Inflation converges to the monetary authorities' target, typically $2 \%$ annually. Interest payments are determined by the stock of debt and an interest rate that is based on a mix of long and shortterm rates, with the long-term rate including a premium of 4 basis points for each percentage point of financial liabilities in excess of $75 \%$ of GDP. Japan is assumed to remain unusual, with the very high share of domestic financing keeping the risk premium at only 1 basis point for each percentage point of financial liabilities in excess of $75 \%$ of GDP.

- The other major assumptions concern fiscal policy. In the baseline, underlying revenues and primary spending are constant as shares of GDP, though the automatic stabilisers operate while the economy moves back to potential. In some scenarios, ageing-related spending is added to underlying spending to highlight the fiscal pressures coming from population ageing. For health care, given that only a relatively small portion of the projected increase is ageing-related, additional spending is phased in linearly over the projection horizon.

\section{Fiscal gaps}

The long-run projections are used to determine so-called fiscal gaps. ${ }^{11}$ The fiscal gap shows the immediate and permanent improvement in the underlying primary balance that is required to ensure that debt meets a target at a certain point in time (Auerbach, 1994). The presentation of the results below reports the fiscal gaps for ensuring gross financial liabilities are 50\% of GDP in 2050. This is intended to be illustrative and not normative. Results for a variety of different debt targets (returning debt to pre-crisis levels and to 75\%,50\% and 25\% of GDP as well as net debt targets) are reported in Merola and Sutherland (2012). A variety of targets is used as different debt targets will be appropriate for different countries. For example, the lower debt target may be less compelling for countries with large government financial asset holdings. In other cases, where the public has demonstrated a preference for very low levels of debt a high debt target is clearly inappropriate. The debt targets also show the implications for fiscal policy of being ambitious. The fiscal gaps reveal how much extra fiscal tightening is needed to get debt down to a prudent level (25\% and $50 \%$ of GDP).

The fiscal gap calculations can take into account different pressures on fiscal policy, such as ageing, which develop over time. In this light, the fiscal gaps should be seen as giving a common metric for assessing the need for fiscal consolidation rather than saying anything about how such a consolidation can be implemented. When the fiscal gap is large, it may be difficult to implement such a large consolidation effort immediately. Furthermore, sustaining the fiscal policy tightening, even seemingly modest ones, over very long periods may also present a considerable challenge. Finally, as the fiscal gaps are based on meeting arbitrary debt targets in 2050, the evolution of gross financial liabilities is unlikely to be stable as a

11. These calculations are related to the fiscal gap calculations of national administrations and those in the European Commission's Sustainability Reports (so called S1 and S2 indicators). Differences exist in the structure of the models and the assumptions, as well as the debt targets and projection horizon. The results reported here should be seen as complements, exploring the implications of alternative debt targets as well as potential threats to, and policies that may support fiscal consolidation. 
share of GDP at the end of the simulation. In some cases, reported below, the fiscal gap will involve substantial undershooting of the debt target early in the simulation, masking pressures on public finances that will continue to mount beyond 2050.

\section{The starting point}

The starting point for the fiscal gap simulations is 2012, with the deficit and debt data taken from the spring 2011 Economic Outlook projections (OECD, 2011e). As such, the starting point already embodies expected fiscal tightening. In some cases this tightening is substantial (Figure 3.1). Between the trough (measured by the underlying primary balance) following the onset of the crisis in 2007 and the projected value for 2012, five countries are expected to tighten by more than 5\% of GDP (Greece, Iceland, Ireland, Portugal and Spain), with Greece having a projected underlying primary surplus of 3.5\% of GDP in 2012 as compared to a deficit of $8.9 \%$ of GDP in $2009 .{ }^{12}$ These are very large and rapid consolidations by historical comparison (see section 4). In 11 other countries, underlying primary balances are expected to tighten by more than $2 \%$ of GDP.

Figure 3.1. Cumulative fiscal tightening between the deficit trough and 2012

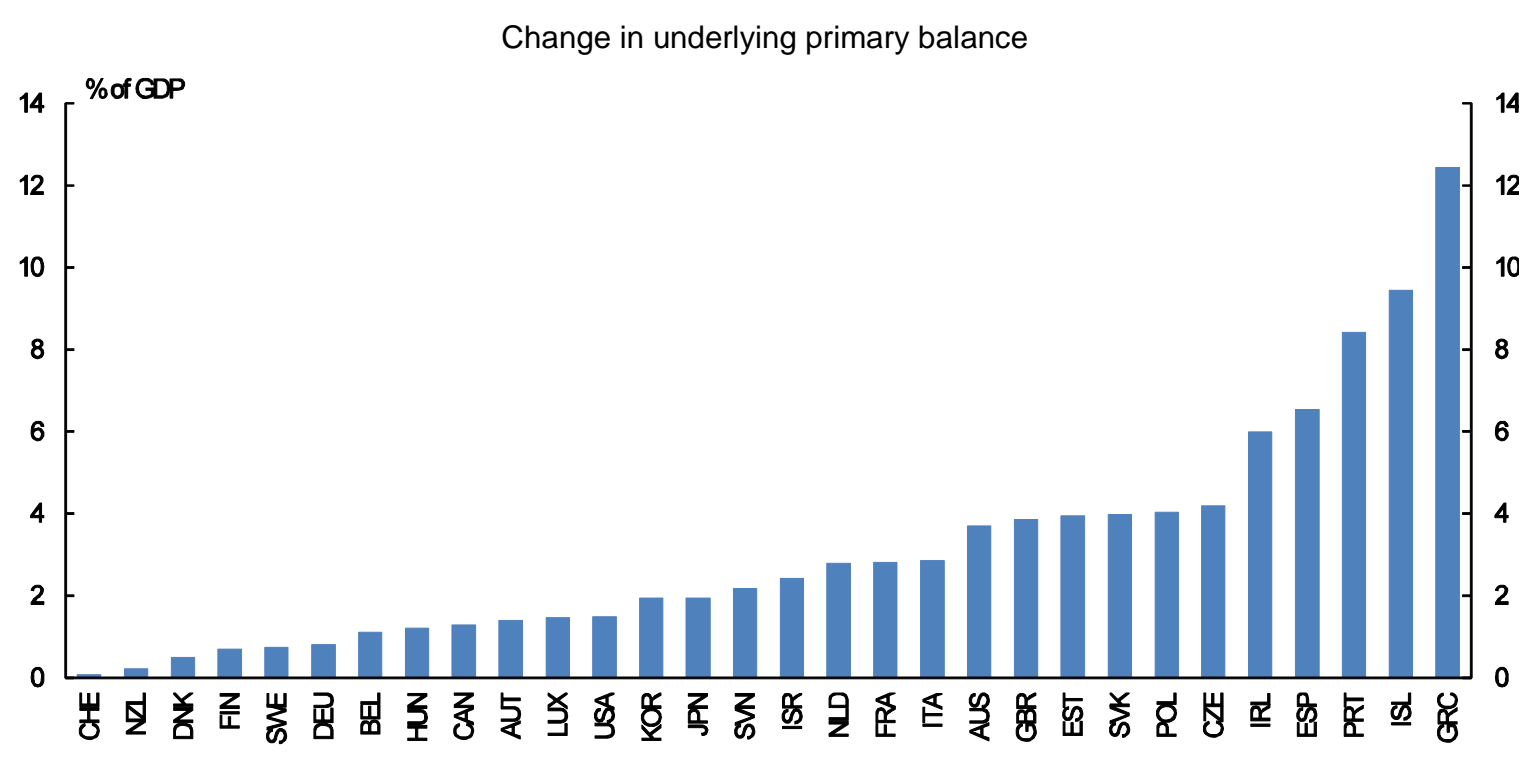

Source: OECD Economic Outlook 89 Database.

\section{Baseline simulation}

The baseline simulation shows the immediate tightening of the underlying primary balance in 2013 needed to ensure that debt is $50 \%$ of GDP in 2050. The baseline assumes that pension, health and longterm care spending is constant as a share of GDP and, as such, the fiscal gaps present the minimum that is required to meet consolidation needs (simulations incorporating spending pressures emanating from pensions, health and long-term care are presented below). Considerable differences across countries emerge (Figure 3.2), which are similar to an alternative approach to quantify consolidation needs (Box 3.3). Countries differ mainly because of large differences in underlying deficits at the starting point and to some extent in the level of initial debt (Table 3.2). Countries already undertaking large fiscal

12. Following a severe economic dislocation, estimating potential output and thereby the underlying primary balance represents a challenge. While the fiscal gap simulations do not directly assess uncertainties about potential output, the variety of simulations reported below reveal how varying different parameters affect the fiscal gap calculations. 
consolidations (Greece, Iceland, Portugal and Spain) generally face moderate fiscal gaps on the assumption that the large improvements in underlying primary balances are maintained. Countries where underlying deficits are expected to remain substantial in 2012 face much larger fiscal gaps. For example, the fiscal gaps for Japan, the United States, the United Kingdom and New Zealand exceed 5\% of GDP. On the other hand, a number of countries - Korea, Luxembourg, Sweden and Switzerland - do not face any additional tightening requirements to meet the debt target.

The fiscal gaps do not change markedly relative to the baseline if alternative debt targets are used (Figure 3.3). This occurs because even relatively small changes to underlying fiscal positions add up when maintained for 40 years. In some cases, the fiscal gaps show larger changes if the target is to return debt to the pre-crisis level. For example, given their low debt levels prior to the crisis, Luxembourg and Australia would face a fiscal gap of around 1\% of GDP if they wanted to return to their pre-crisis debt level. At the other extreme, for Japan, returning to the very high pre-crisis debt level is somewhat less onerous, but the fiscal gap remains large. The fiscal gap calculations suggest that the extra degree of fiscal consolidation needed to bring debt down to more prudent levels is relatively modest, if implemented over a long period. Taking government assets into consideration may indicate that fiscal positions are in better shape. ${ }^{13}$ In several countries net debt was zero or even negative. ${ }^{14}$ Given the lower net debt levels, only a small fiscal consolidation effort is typically required to reach a target of net debt equal to $25 \%$ of GDP. In some cases, net positions are sufficiently favourable that no consolidation is required, such as in Finland where the large net asset position reflects pre-funding for pension spending, and the magnitude of the required fiscal adjustment is changed markedly for Japan.

\section{Figure 3.2. Baseline fiscal gaps}

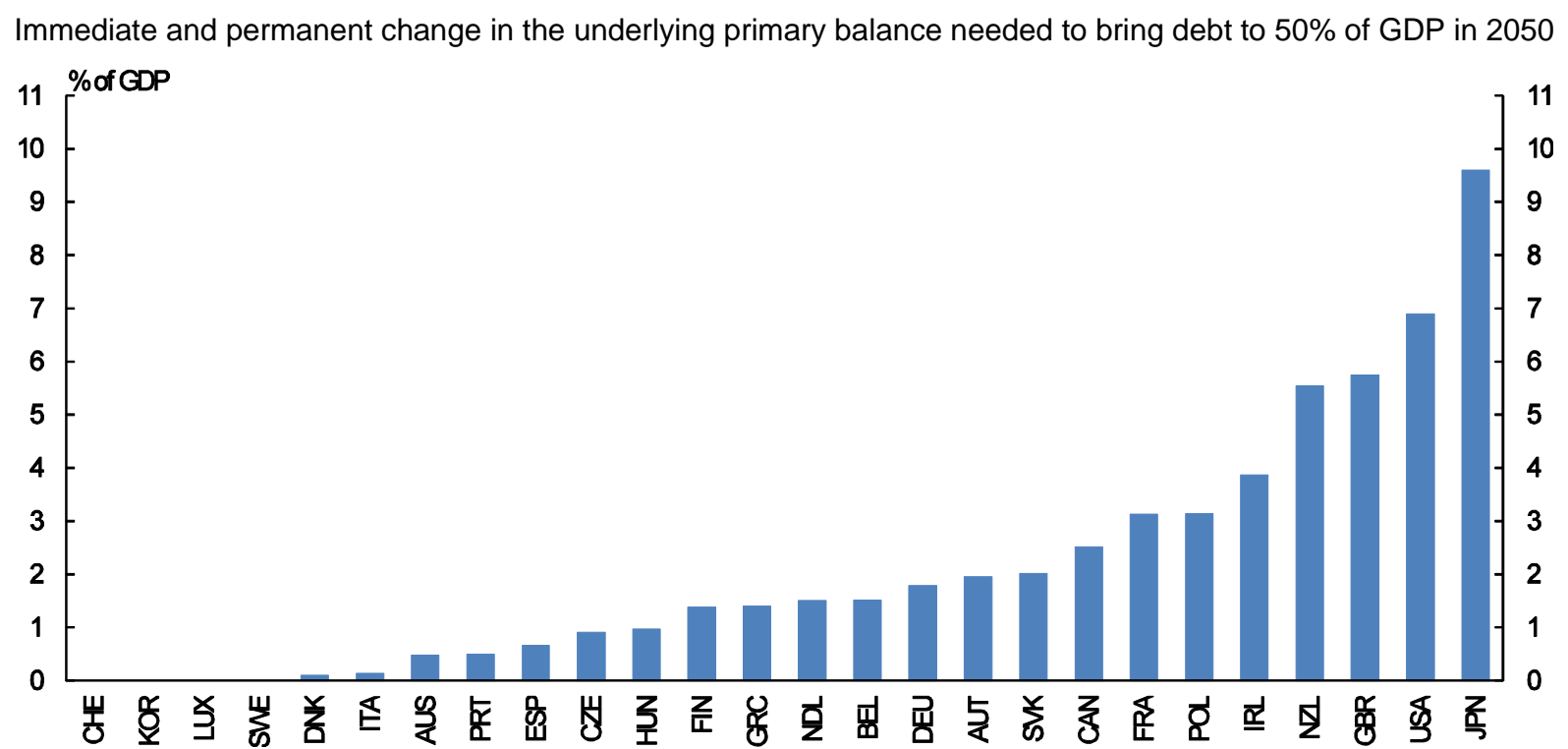

Note: The change is from the underlying primary balance projected for 2012 . The baseline simulation does not include spending pressures from pension, health and long-term care spending.

13. For example, the proceeds from selling financial assets can be used to reduce gross financial liabilities, while leaving net debt unchanged. This implies a reduction in debt servicing costs, and possibly reductions in government bond rates, if markets perceive that fiscal sustainability has improved. However, the sale of assets also eliminates income earned on them. The net effect depends, inter alia, on the difference between the interest rate paid on debt and the rate of return earned on assets. If the former exceeds the latter, the sale of assets will improve debt dynamics via the net interest payments effect.

14. Sometimes, sizeable asset levels reflect the response to the financial crisis, as financial assets in the government sector increased substantially due to the recapitalisation or takeover of financial institutions. 
Figure 3.3. Fiscal gaps for alternative debt targets

Change in underlying primary balance needed so that gross financial liabilities equal $75 \%, 50 \%$ or $25 \%$ of GDP or returns to the 2007 level in 2050

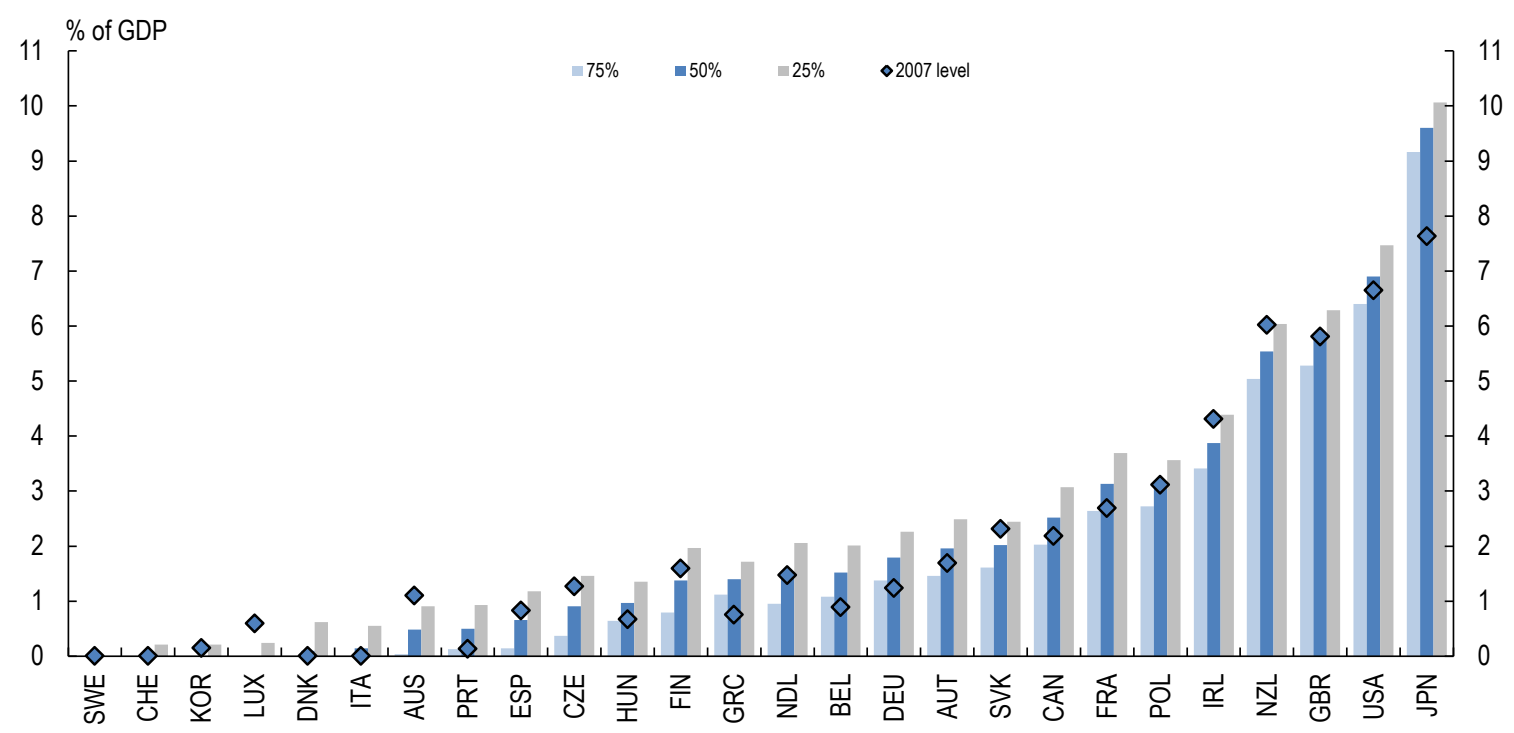

Note: The change is from the underlying primary balance projected for 2012.

Table 3.2. Key assumptions in the baseline simulation

\begin{tabular}{lrr|cc}
\hline & \multicolumn{2}{c|}{ Starting point, 2012 } & \multicolumn{2}{c}{ Average over simulation } \\
\cline { 2 - 5 } & $\begin{array}{c}\text { Gross financial } \\
\text { liabilities, \% of GDP }\end{array}$ & $\begin{array}{c}\text { Underlying primary } \\
\text { balance, \% of GDP }\end{array}$ & $\begin{array}{c}\text { Effective interest } \\
\text { rate }\end{array}$ & $\begin{array}{c}\text { Nominal } \\
\text { GDP growth }\end{array}$ \\
\cline { 2 - 5 } Australia & 31 & 0.6 & 6.9 & 4.8 \\
Austria & 82 & 0.1 & 4.4 & 3.5 \\
Belgium & 100 & 0.9 & 4.7 & 3.8 \\
Canada & 88 & -1.8 & 4.9 & 4.2 \\
Czech Republic & 51 & 0.3 & 4.4 & 4.2 \\
Denmark & 60 & 0.8 & 5.0 & 3.5 \\
Finland & 66 & 0.8 & 4.2 & 3.9 \\
France & 100 & -0.6 & 4.1 & 3.6 \\
Germany & 87 & 0.6 & 4.3 & 3.0 \\
Greece & 159 & 3.5 & 5.5 & 3.4 \\
Hungary & 81 & 1.1 & 5.8 & 4.3 \\
Ireland & 126 & -0.4 & 4.7 & 3.1 \\
Italy & 128 & 3.3 & 4.6 & 2.2 \\
Japan & 219 & -4.2 & 3.0 & 3.2 \\
Korea & 33 & 0.5 & 4.9 & 4.9 \\
Luxembourg & 24 & 2.0 & 4.5 & 3.5 \\
Netherlands & 75 & 0.0 & 4.3 & 4.3 \\
New Zealand & 52 & -4.0 & 5.8 & 3.2 \\
Poland & 66 & -1.5 & 5.3 & 3.1 \\
Portugal & 116 & 3.5 & 4.6 & 2.8 \\
Slovak Republic & 51 & -1.7 & 5.1 & 3.5 \\
Spain & 75 & 0.5 & 4.2 & 4.0 \\
Sweden & 41 & 2.6 & 4.7 & 2.9 \\
Switzerland & 37 & 1.2 & 2.9 & 4.1 \\
United Kingdom & 93 & -3.0 & 4.6 & 4.3 \\
United States & 107 & -5.8 & & \\
\hline
\end{tabular}


ECO/WKP(2012)9

Table 3.3. Fiscal gaps for gross and net debt targets

\begin{tabular}{|c|c|c|c|c|c|c|}
\hline & \multicolumn{4}{|c|}{$\begin{array}{c}\text { Baseline } \\
\text { Gross financial liabilities target }\end{array}$} & \multicolumn{2}{|c|}{$\begin{array}{c}\text { Baseline } \\
\text { Net financial liabilities } \\
\text { target }\end{array}$} \\
\hline & 2007 level & $75 \%$ of GDP & $50 \%$ of $G D P$ & $25 \%$ of GDP & $25 \%$ of $G D P$ & $0 \%$ of $G D P$ \\
\hline Australia & 1.10 & 0.04 & 0.48 & 0.91 & 0.43 & 0.93 \\
\hline Austria & 1.69 & 1.46 & 1.96 & 2.49 & 1.74 & 2.31 \\
\hline Belgium & 0.89 & 1.08 & 1.52 & 2.01 & 1.58 & 2.13 \\
\hline Canada & 2.18 & 2.03 & 2.52 & 3.07 & 1.93 & 2.46 \\
\hline Czech Republic & 1.27 & 0.37 & 0.91 & 1.46 & 0.45 & 1.04 \\
\hline Denmark & 0.00 & 0.00 & 0.10 & 0.62 & 0.00 & 0.07 \\
\hline Finland & 1.59 & 0.79 & 1.38 & 1.97 & 0.00 & 0.02 \\
\hline France & 2.69 & 2.64 & 3.13 & 3.69 & 2.85 & 3.44 \\
\hline Germany & 1.24 & 1.38 & 1.79 & 2.26 & 1.55 & 2.05 \\
\hline Greece & 0.75 & 1.12 & 1.40 & 1.72 & 1.25 & 1.62 \\
\hline Hungary & 0.67 & 0.64 & 0.97 & 1.35 & 0.86 & 1.29 \\
\hline Ireland & 4.31 & 3.41 & 3.87 & 4.39 & 3.43 & 3.97 \\
\hline Italy & 0.00 & 0.00 & 0.14 & 0.55 & 0.07 & 0.52 \\
\hline Japan & 7.63 & 9.16 & 9.60 & 10.06 & 4.93 & 5.74 \\
\hline Korea & 0.15 & 0.00 & 0.00 & 0.21 & 0.00 & 0.00 \\
\hline Luxembourg & 0.59 & 0.00 & 0.00 & 0.24 & 0.00 & 0.00 \\
\hline Netherlands & 1.47 & 0.95 & 1.50 & 2.06 & 1.14 & 1.74 \\
\hline New Zealand & 6.02 & 5.04 & 5.54 & 6.04 & 5.13 & 5.68 \\
\hline Poland & 3.11 & 2.72 & 3.14 & 3.56 & 3.00 & 3.46 \\
\hline Portugal & 0.13 & 0.13 & 0.50 & 0.93 & 0.38 & 0.84 \\
\hline Slovak Republic & 2.31 & 1.61 & 2.02 & 2.44 & 2.03 & 2.48 \\
\hline Spain & 0.83 & 0.14 & 0.66 & 1.18 & 0.60 & 1.16 \\
\hline Sweden & 0.00 & 0.00 & 0.00 & 0.00 & 0.00 & 0.00 \\
\hline Switzerland & 0.00 & 0.00 & 0.00 & 0.21 & 0.00 & 0.00 \\
\hline United Kingdom & 5.81 & 5.28 & 5.75 & 6.29 & 5.56 & 6.15 \\
\hline United States & 6.65 & 6.40 & 6.90 & 7.47 & 6.95 & 7.59 \\
\hline
\end{tabular}

\section{Box 3.3. Fiscal gaps and consolidation requirements to stabilise debt}

The fiscal gaps reported in this paper are distinct from recent work by the OECD that has assessed the consolidation requirements to stabilise debt (OECD, 2011e). These requirements are based on stylised assumptions about a sustained gradual annual tightening of the underlying primary balance by $0.5 \%$ of GDP until debt stabilization is reached. The fiscal gaps on the other hand make the alternative stylised assumption that the tightening will be implemented immediately and sustained until 2050 to meet a specific debt target. Both sets of assumptions ignore the implications for output, which will obviously be important.

Overall the two approaches produce similar rankings of consolidation needs across counties (Figure 3.4). The two approaches differ in three ways. First the time path of consolidation is different. Second, the final debt level is different. Third, the time horizon is different. The first and third differences in particular pull in opposite directions for the two approaches. The combined effect of the differences leads to the additional tightening to bring debt down to $50 \%$ of GDP in 2050 being typically not much greater than the gradual fiscal tightening needed after 2012 to stabilise debt levels. In general, the immediate consolidation assumed by the fiscal gap calculations is sufficient to bring debt dynamics under control more quickly which combined with the assumption that the fiscal tightening is permanent over a longer time horizon will see debt levels gradually fall for the rest of the simulation. The estimates of the amount of consolidation needed to stabilise debt are particularly large for the United States and Japan and the gradual tightening takes considerably longer to stabilise debt. As a higher interest premium for each percentage point of debt above $75 \%$ of GDP is assumed for the United States than Japan, the consequences of the gradual tightening for adverse debt dynamics are more severe, which explains why the relationship with the fiscal gap estimates differs from the other countries. If countries do not need to consolidate to meet the terminal debt target, such as in the case of Sweden, no fiscal gap is calculated and the country is excluded from the figure. 
Figure 3.4. Relation between fiscal gaps and consolidation requirements

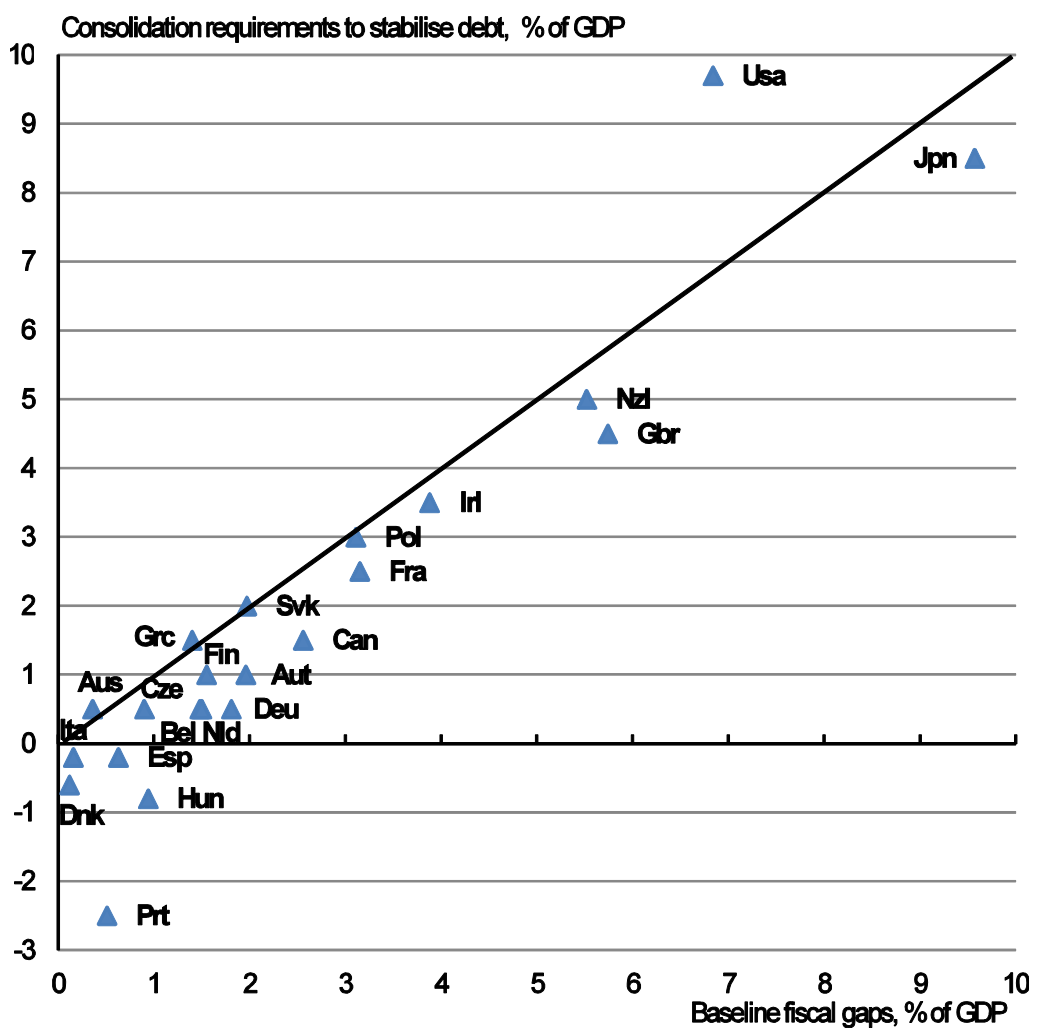

Source: OECD (2011e), OECD Economic Outlook 89.

\section{How much of a safety margin is needed to meet the baseline target?}

The fiscal gaps needed to meet the debt targets in the baseline simulation fail to take into account how shocks can derail fiscal consolidation. For example, governments may need to deal with contingent liabilities that arise as a result of a banking crisis or other more prosaic shocks could hit that are part and parcel of budget implementation. Obviously, with respect to the financial sector, the amount of safety margin will be related to the quality of micro and macro-prudential regulation. To assess the possible importance of shocks two scenarios examine how a country's own history and the OECD-wide experience of debt shocks may alter the desirable amount of tightening.

The first set of scenarios uses country-specific shocks to debt to examine the potential threats to consolidation requirements. The shocks are taken from the country's own history (including the recent crisis) of changes in debt, such as one-offs and valuation effects that are not explained by budget balances, interest rates, inflation and growth. The simulations draw on these error terms and their historical distribution and the results are used to create a distribution of possible debt outcomes and then calculate the fiscal gaps. ${ }^{15}$ The fiscal gaps are calculated as the additional tightening (or smaller tightening if past shocks have tended to be favourable) that is required to meet a $75 \%$ probability of reaching the terminal debt target (Figure 3.5). The results from these stochastic simulations show that a handful of countries would require stronger tightening (Denmark, Greece, Ireland, Japan, Portugal and the United States). In most

15. The fiscal gap is the average from 500 separate runs of the stochastic simulations. 
other countries considering debt shocks does not make much difference, possibly reflecting positive and negative shocks that cancel out. In other cases, such as Germany, past debt shocks have tended to be slightly beneficial.

Figure 3.5. Fiscal gaps from stochastic simulations

Change in underlying primary balance needed so that gross financial liabilities are 50\% of GDP in 2050 and change needed to ensure meeting this target with $75 \%$ probability when the baseline is hit by shocks

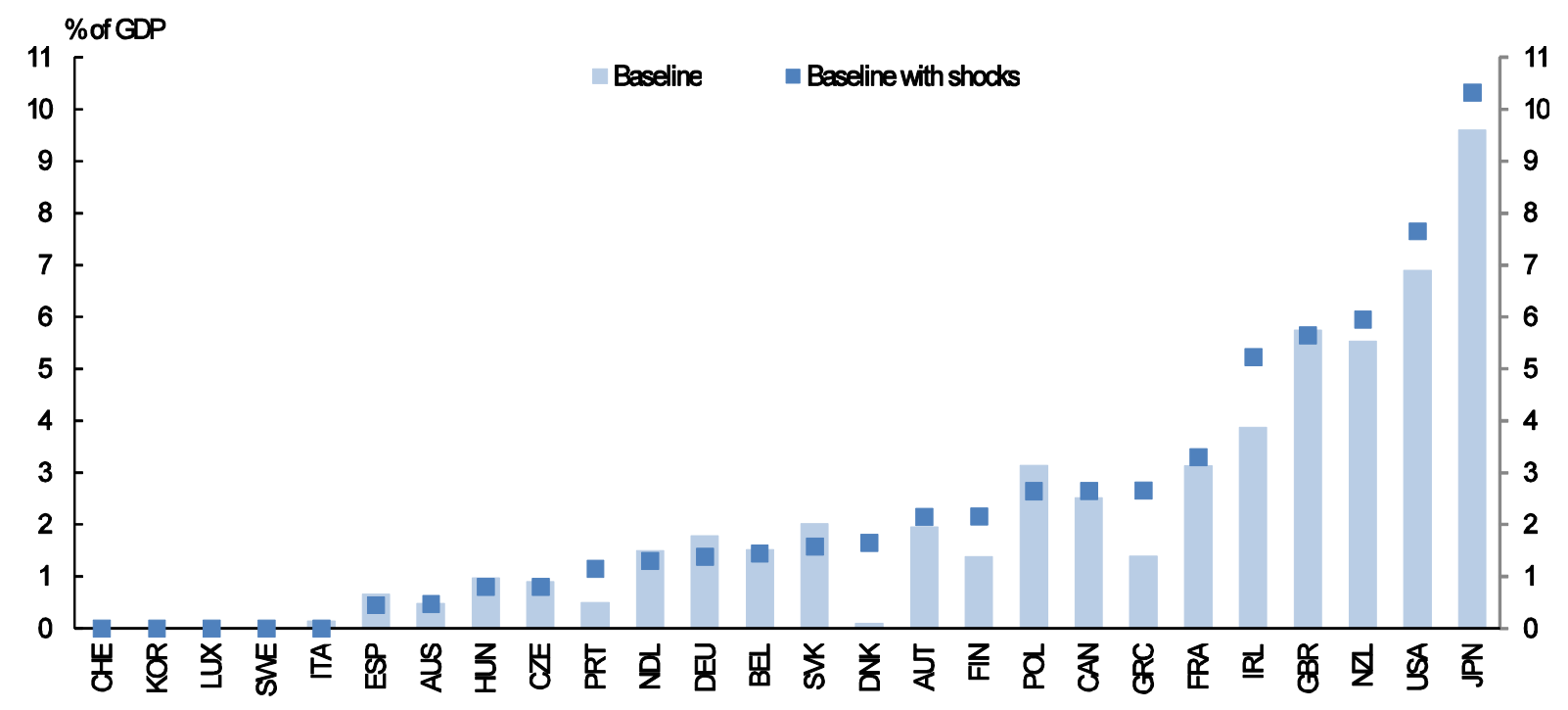

Note: The change is from the underlying primary balance projected for 2012.

The second set of scenarios examines shocks calibrated on the distribution of shocks for all OECD countries. The approach is similar to the country-specific shocks, but the shocks are drawn from the OECD distribution of one-off (but not valuation) shocks to debt. ${ }^{16}$ While most observations are close to zero the distribution is highly skewed with a few very large one-off additions to debt. The fiscal gaps are calculated as the additional tightening that is required to meet a $75 \%$ probability of reaching the terminal debt target (Merola and Sutherland, 2012). In general, the additional permanent tightening to meet these types of shocks adds a little under $1 / 2$ per cent of GDP to the fiscal gap. But due to the highly skewed distribution of shocks setting a higher probability threshold for meeting the debt target raises the desirable fiscal tightening further.

\section{How were similar challenges met in the past?}

This section provides a brief snapshot of past debt developments and features of consolidations coupled with the reporting of results from econometric analysis and case study evidence from large fiscal consolidations, drawing on Molnar (2012) and Blöchliger et al. (2012).

\section{Past consolidations: empirical evidence}

When episodes of tightening of the underlying primary balance occurred in the past, the typical size was around 3\% of GDP, though larger consolidation episodes could reach 11\% of GDP. When consolidations relied on a rapid tightening averaging just over $2 \%$ of GDP per year they typically relied

16. The distribution is taken from the estimates of one-offs used to calculate underlying fiscal balances in OECD (2011e). 
more on changes in revenue and the tightening process usually lasted a single year. In a given year, the amount of tightening has on occasion exceeded 5\% of GDP. Fiscal consolidations that were based on a sustained gradual tightening - around 1\% of GDP per year on average - tended to rely on both spending and revenue sources and lasted around four years on average, but could extend over a decade.

Econometric analysis of past consolidation episodes suggests that a number of economic conditions and policies have been conducive to fiscal consolidation and debt stabilisation. Some care is needed in interpreting the evidence as different definitions of fiscal consolidation can have implications for the findings. ${ }^{17}$ Bearing this caveat in mind, econometric evidence using a number of different definitions of consolidation suggests that economic conditions, consolidation design as well as the political settings support debt stabilisation (a "successful consolidation"), encourage governments to start to consolidate, boost the size and the intensity of consolidation episodes, and prompt governments to continue the adjustment once started.

\section{Economic conditions}

The empirical analysis reported in Molnar (2012) identifies a number of economic conditions that affect the probability that consolidation measures succeed in stabilising debt. Successful consolidation episodes are typically supported by somewhat stronger growth than consolidation periods in general (Figure 4.1). Likewise, falling interest rates help debt stabilisation through reducing debt servicing costs and cushioning the contractionary impact of consolidation. Depreciation of the nominal effective exchange rate seems to be conducive to reducing debt, which may work through competitiveness gains boosting exports, and also appears to lengthen the consolidation episode. These results hold out limited promise of successful consolidation in current circumstances, when growth is fairly modest and interest rates are already relatively low, whereas for the euro area countries any boost from the exchange rate will be limited as extra-euro area trade is small except for a few countries. ${ }^{18}$

\section{Policy design}

The design of a consolidation package appears to influence its outcome, particularly its probability of stabilising debt (fiscal rules are discussed below). Consolidations that are based on restraining spending appear to be more effective in stabilising debt and be more durable. However, large consolidations have a higher probability of success, if achieved by multiple instruments, including both revenue and spending items. Of the specific spending categories, a reduction in social security spending can increase the probability of debt stabilisation, but large cuts may not be sustainable. Depending on the definition of the consolidation, there is some evidence that cutting subsidies or government wages may help stabilise debt. Relying on cuts of other items, such as social protection and housing, may boost the size of the consolidation, though they do not seem to affect whether the consolidation succeeds in stabilising debt.

17. Previous evidence has tended to rely on econometric evidence or case studies. The evidence from case studies is hard to generalise and econometric work suffers from relying on an ex post treatment of the data to identify when fiscal consolidation started. A notable exception is Guajardo et al. (2011).

18. The empirical work also considered the impact of banking crises on fiscal consolidation. Fiscal adjustment programmes during or immediately following banking crises appear to be less successful in stabilising debt, though this result is not robust to altering the definition of the consolidation episode. 
Figure 4.1. Growth around consolidations

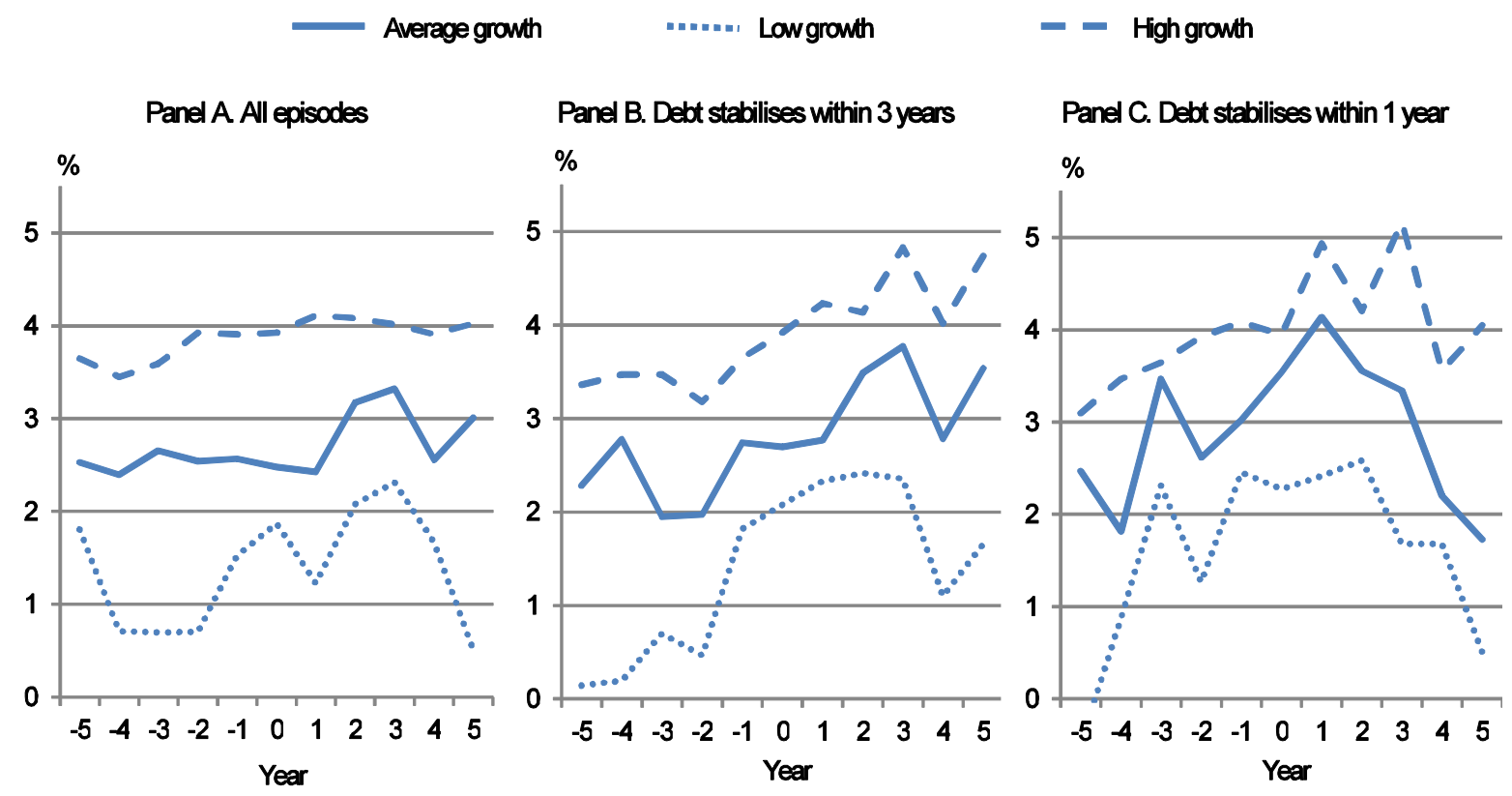

Note: Consolidation is defined as a tightening of more than $1.5 \%$ of GDP in a single year. Year 0 is the year that a fiscal consolidation is implemented, with the figure showing the 5 years preceding and following the consolidation. The solid line shows the median observation for a given year, while "high" and "low" growth report the observation at the 75th and 25th percentile, respectively. Panel $\mathrm{A}$ is based on all consolidation episodes, Panel B is based on episodes that succeeded in stabilising debt after 3 years, while Panel $\mathrm{C}$ is based on episodes that succeeded in stabilising debt the following year.

\section{Political and fiscal-federal settings}

The political setting also matters for the success of consolidation: more centrist governments appear more likely to stabilise debt and newly-elected governments seem to be more likely to start a consolidation and to continue one. However, the findings related to the political environment are susceptible to omitted variable problems and reverse causality. For instance, if the electorate cares about fiscal discipline, it is likely to elect a government that is more likely to pursue fiscal prudence.

In some cases sub-central governments appear to support consolidation. State-level governments pursuing a fiscal tightening can improve the chances of stabilising overall debt. At the local government level, the sensitivity of the estimates to the inclusion of particular countries suggests that in some cases (Canada and Korea) local government actions may hinder the success of a consolidation. This may occur either as a reaction to central government trying to shift the burden to other levels of government or as a reflection of the nature of sub-central government spending. For instance, central governments could be tempted to reduce transfers to lower levels of government or burden them with new unfunded spending responsibilities. If this results in ballooning deficits at the sub-central level of government, consolidation efforts could be undermined. In other cases, sub-central governments are responsible for politically sensitive spending, such as health and education, and they could be reluctant to contribute to a consolidation driven by the central government. In this context, governments may need to guard against fiscal liabilities developing at sub-central levels of government.

\section{Large consolidations: case study evidence}

Unlike for many past fiscal consolidations, the required fiscal tightening is currently large in many countries and consolidation efforts will have to be sustained for many years. Nonetheless, while the required tightening is often large, it is not without precedent. Some OECD countries implemented large 
and sustained consolidations in the past, with episodes extending over several years, during which budgets improved considerably and debt tended to stabilise and then shrink (Box 4.1 and Blöchliger et al. 2012).

\section{Box 4.1. Large fiscal consolidations}

This box provides a summary of 13 of the largest consolidation episodes in terms of deficit reduction since $1980 .{ }^{1}$ The main features of these consolidations are:

Large swings in underlying budget balances were generally implemented over a prolonged period. Debt often began to stabilise a few years after the fiscal tightening began, but often remained above the level before the consolidation began. The government spending-to-GDP share fell, particularly when spending was large relative to GDP. Furthermore, the spending composition tended to change with investment one of the principal casualties. The share of revenues in GDP generally rose gradually prior to and during the consolidation episodes.

The macroeconomic environment often supported the consolidations and indeed had already turned favourable before consolidation started. Typically growth rates picked up before fiscal tightening began, with the output gap beginning to close although unemployment rates started to decline a bit later. Growth generally returned to robust rates relatively quickly, though sometimes stalled. The favourable growth developments often reflected improving competitiveness. Either prior to or accompanying the beginning of consolidation large currency depreciations strengthened current account balances both before and during consolidation. Interest rate developments also often supported consolidation, particularly once it was underway. Long rates on government bonds tended to fall during a consolidation, but only once it was well underway.

In most cases, improving primary balances contributed to bringing debt under control (often changing from negative to positive when debt was reduced) with relatively little role played by the net effect of real interest and growth rates. In the case of Italy during the 1990s, however, positive real interest rate effects initially swamped the relatively large primary surpluses and other effects on debt dynamics, contributing to leaving debt $25 \%$ of GDP higher at the end of the consolidation episode. For both Japan and the United Kingdom, a significant tightening of the underlying primary balance was insufficient to bring debt down until after the tightening finished.

Finally, pursuing a consolidation was often not harmful to the incumbent government's election chances. Most consolidation episodes were implemented shortly after an election. More than half of the governments that had started consolidation were re-elected, and some strengthened consolidation efforts after re-election. In some cases, an incoming government continued the consolidation.

1. The consolidation episodes were selected on the basis of measuring the trough-to-peak of the underlying primary balance using a business cycle dating methodology. The episodes selected were: Australia (1984-88, 1995-98), Canada (1993-97), Denmark (1983-86), Finland (1993-2000), Greece (1990-94), Ireland (1982-88), Italy (1990-95), Japan (1979-87), Sweden (1981-87, 1994-97), United Kingdom (1993-98), and United States (1993-98).

\section{Debt dynamics}

One possible decomposition of past debt dynamics highlights the relative contribution of real growth and real interest rates to the primary balance. ${ }^{19}$ This decomposition shows the difference between the inertial contribution of debt dynamics on the one hand and the more direct policy lever of the primary balance on the other. As can be seen in Figure 5.1, when debt is falling this is typically accompanied by a positive primary balance (and thus having a negative effect on debt in the figure). The real interest rate and real growth rate effects often largely offset one another. In some countries during the early 1970s, negative real interest rates reduced debt. However, in the case of Italy, this was insufficient to bring debt down, largely as a result of valuation effects, which may have stemmed from problems associated with rolling over substantial amounts of debt in a high inflation environment.

19. There are a number of ways to decompose debt dynamics, though none will give an exact decomposition. 
Figure 5.1. Decomposition of debt dynamics

Contribution to change in gross financial liabilities (excluding one-offs) as a share of GDP
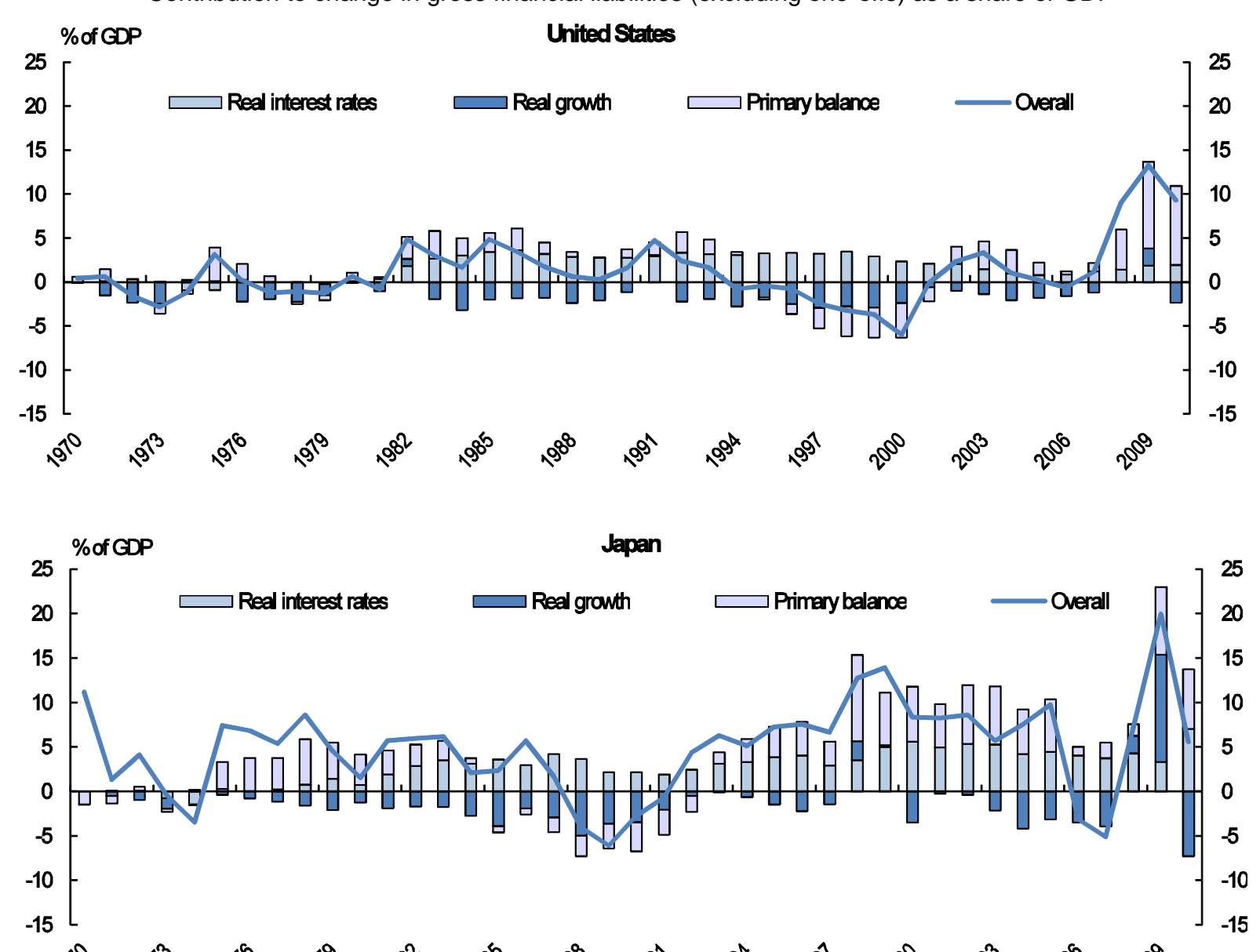

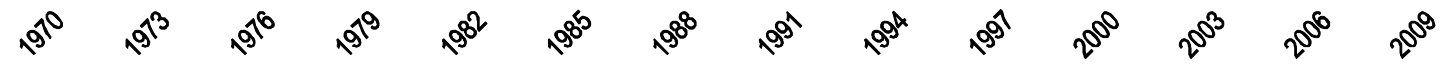

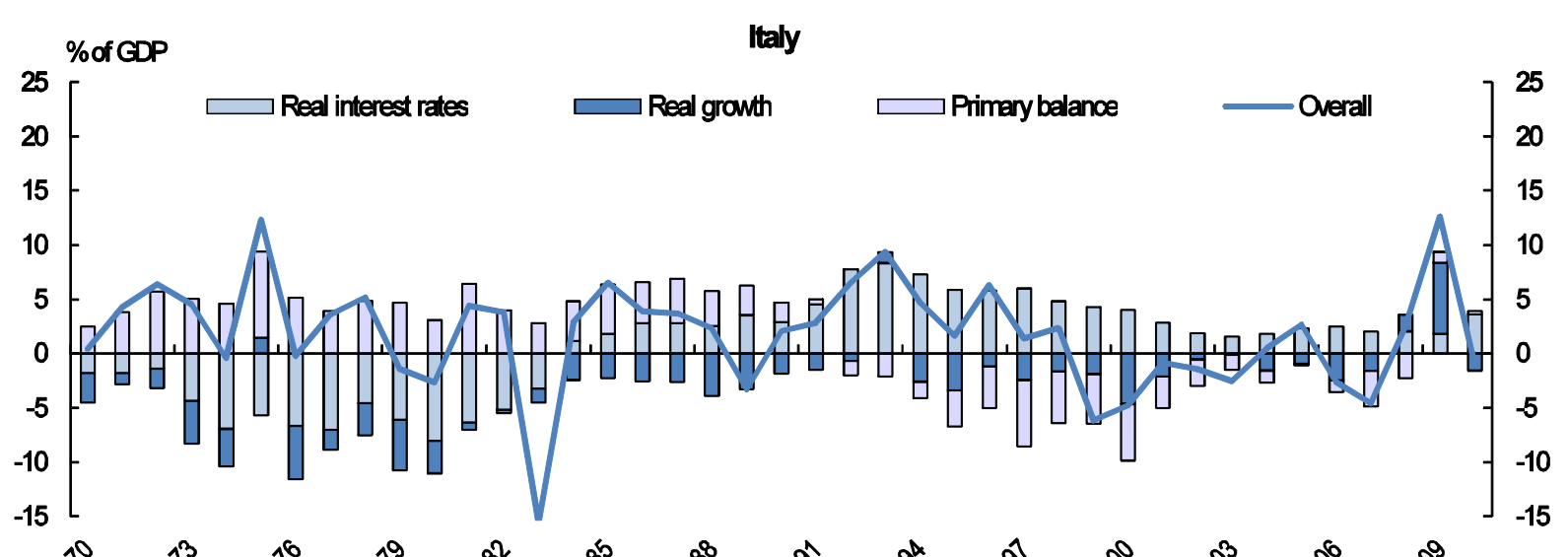

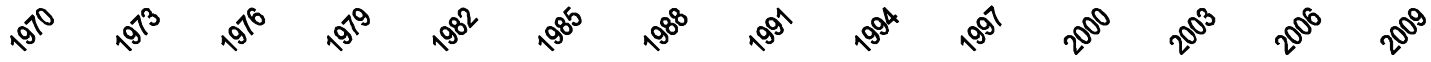

Source: OECD Economic Outlook 89 Database. 


\section{The effects of stronger productivity growth}

Debt dynamics can be influenced by stronger productivity growth on economic activity. Structural reforms can contribute to longer-term fiscal consolidation by fostering productivity growth (OECD, $2010 f) .{ }^{20}$ The impact of stronger productivity growth can be examined using fiscal gaps. In the simulations, productivity growth increases by $1 / 4$ of a percentage point and remains at this higher rate throughout the simulation and thus has a mechanical effect on the fiscal gap through the denominator. Interest rates are assumed not to change, although they would likely rise with a boost in productivity undoing some of the potential gains. Nonetheless, compared to the baseline results, stronger productivity growth reduces fiscal gaps only modestly, with the effects generally larger for countries with large debt to GDP ratios (Figure 5.2). ${ }^{21}$ This is largely due to the assumption that primary revenues and spending are constant shares of GDP with the consequence of a sustained imbalance in the underlying budget balance often more important than the initial debt positions over a long period. If government spending did not rise fully in line with GDP, however, the gains from higher growth could be substantial. Indeed when efficiency gains are assumed for government spending, several countries would no longer need a fiscal tightening to reach the $50 \%$ debt-to-GDP ratio. For the countries with the largest fiscal gaps, while productivity gains would help, the required fiscal tightening remains large.

Figure 5.2. Fiscal gaps with productivity shocks and spending efficiency

Change in underlying primary balance needed to bring gross financial liabilities to $50 \%$ of GDP in 2050

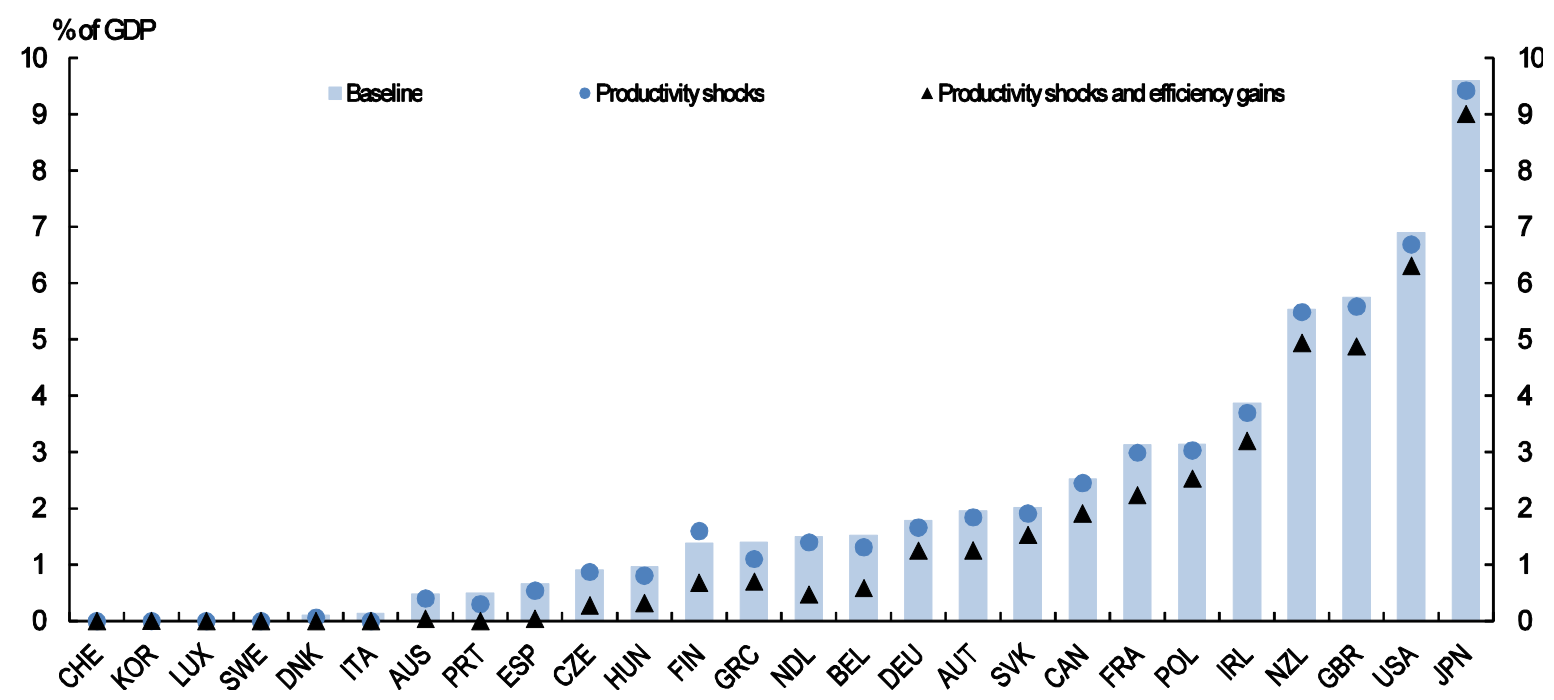

Note: The change is from the underlying primary balance projected for 2012. In the simulations, interest rates remain at their baseline level and government financial assets are assumed to remain constant as a share of GDP. Government spending efficiency is assumed to reduce spending by $0.9 \%$ of GDP by 2050.

\section{Inflation and interest rates}

One possible way to deal with high debt levels is to erode it through higher inflation, though this is likely to be accompanied by drawbacks. Through its effect on the denominator, the debt to GDP ratio can

20. Recent work by Bouis and Duval (2011) estimated that the overall potential GDP gain for the average OECD country from undertaking a wide range of ambitious product and labour market reforms might come close to $10 \%$ over 10 years, compared with a no-reform baseline scenario.

21. In the case of Finland, the large holdings of government assets fall as a share of GDP. By holding the asset ratio constant in the simulations this raises the fiscal gap when productivity rises. 
fall over time and - as seen above - high inflation leading to negative real interest rate effects helped some countries reduce their debt loads in the 1970s. This is most likely to have an effect in an environment when debt maturity is relatively long and rollover requirements are low, given that interest rates are likely to respond to higher inflation rates. Even in this case, simulations presented in the OECD Economic Outlook 89 show that the contribution of inflation to reducing debt would require a sustained increase in inflation of 2 percentage points over 10 years to erode the typical amount of debt accumulated between 2007 and 2010 (OECD, 2011e). Getting debt to even lower levels would correspondingly require higher inflation rates.

The interest rates government face on financial liabilities can move for a multitude of reasons (Box 5.1). However, interest rates in the pre-crisis era were probably artificially low and other things being equal are likely to rise in the future, though during a sustained period of fiscal restraint they are likely to remain relatively muted. To make a marked dent in debt levels, some form of financial repression would probably be needed to ensure interest rates remain low relative to inflation. ${ }^{22}$ Following the end of World War II until the beginning of the 1980s, financial repression often played an important role in reducing the huge stocks of debt accumulated during the war. Reinhart and Sbracia (2011) estimate that financial repression contributed to a "liquidation effect", which for example amounted to a reduction of Italian government debt of around 5\% annually. Figure 5.3 presents suggestive evidence of financial repression during the 1970s, during which a large wedge existed between the yield on 10 year government bonds and the effective interest rate the government was paying on debt. While financial repression may be one avenue to liquidate debt there are adverse consequences. For example, Jonung (2011) argues that the imbalances which developed as a cause of financial repression contributed directly to financial crises in the Nordic countries in the late 1980s and early 1990s.

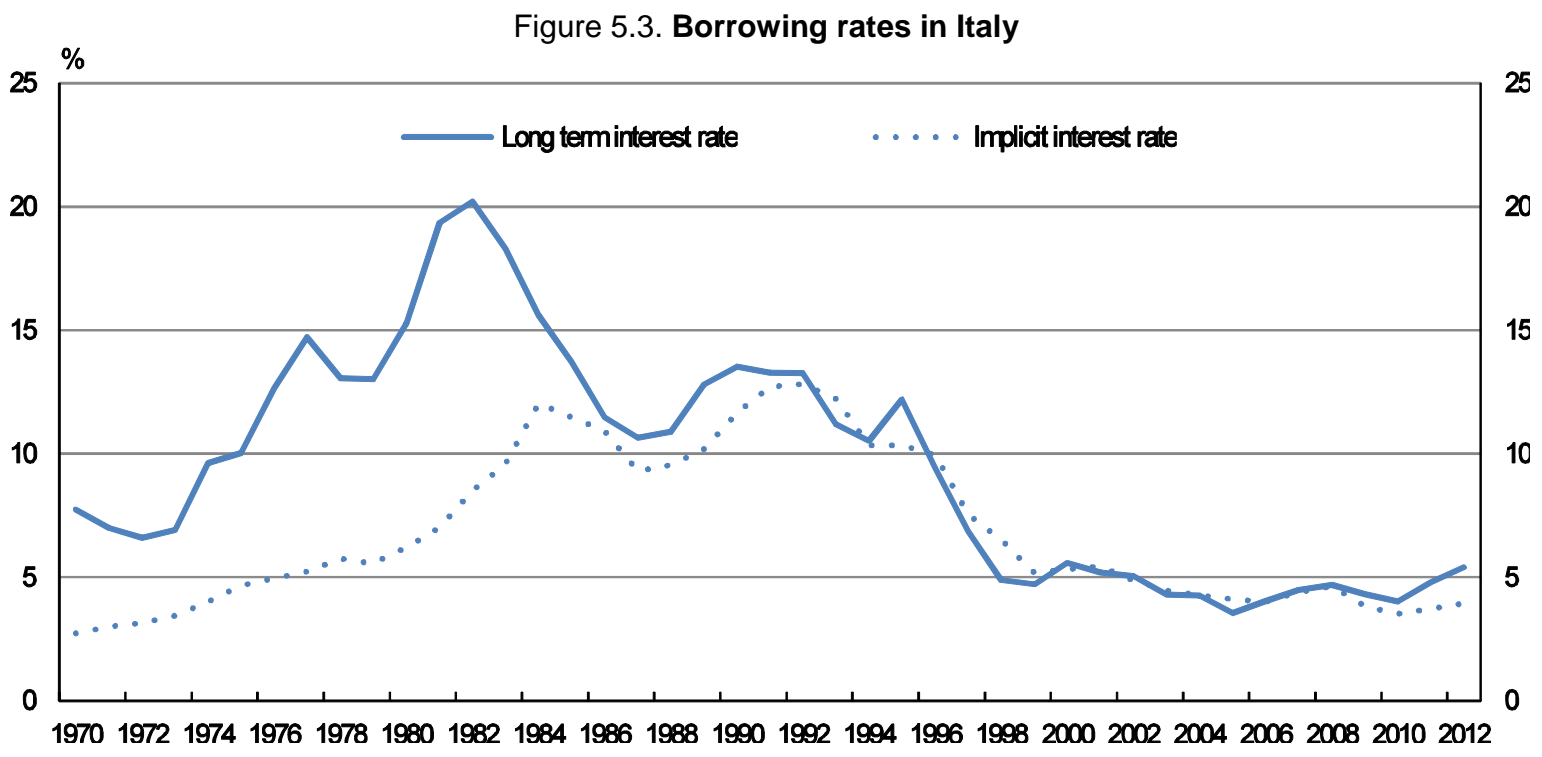

Source: OECD Economic Outlook 89 Database.

22. Financial repression includes directed lending to government by captive domestic lenders, caps on interest rates, regulation of cross-border capital movements and a tighter connection between government and the operation of banks. 


\section{Box 5.1. Factors influencing government borrowing costs}

Over most of the past decade, long-term interest rates in the major OECD countries have been unusually low. While this may partly reflect global factors including lower inflation (Bernanke, 2005; Corden, 2009), it is also a reflection of policy rates that have been unusually low for much of this period, and in retrospect possibly even too low in some cases (Ahrend et al. 2006). Following the crisis, the normalisation of financial conditions and policy rates is likely to involve a general increase in long-term interest rates.

A large number of factors and not just debt can potentially influence government borrowing costs. Market concerns about underlying fiscal positions and also developments outside the control of government can move bond yields significantly. For example, changes in risk aversion, the relative debt and deficit positions across countries and the interaction with current account imbalances, can all play a role and their relative contribution is difficult to pin down. ${ }^{1}$ Furthermore, regulatory requirements for financial institutions such as pension funds can create demand for safe assets or financial instruments with specific characteristics.

In the empirical literature, Laubach (2003) found that a percentage point increase in the debt and deficit-to-GDP ratio raise interest rates by 4 and 25 basis points, respectively. Haugh et al. (2010) identified financial sector soundness, price competitiveness, the fiscal policy track record, tax-to-GDP ratios, short-term refinancing needs, expected deficits, bond market liquidity as well as other institutional and structural factors as determinants of bond yields. Gruber and Kamin (2010) re-examined the impact of debt and deficits on interest rates for the G7. Crowding out, portfolio balance effects (an increase in the interest rate causes a shift in the composition of the portfolio), inflation expectations and default risk premia all play a role. Using country and time fixed effects (credit worthiness and changes in interest rates, respectively) they found for the G7 that a $1 \%$ increase in underlying net lending increases the interest rate by 15 basis points ( 2 basis points for unadjusted net lending). No effect was found for Japan as home bias and deflation have an important impact.

As market reactions can be sharp, countries with higher debt loads - other things being equal - are more likely to be vulnerable. Past interest rate developments suggest that there are non-linear effects with risk premia on government debt rising to a greater extent when gross government debt exceeds around 75\% of GDP (Égert, 2010). Countries approaching fiscal limits will likely see borrowing costs rise. ${ }^{2}$ There can also be knock-on effects on corporate borrowing costs, though the relationship is not unidirectional. Typically, higher interest rates crowd out private sector borrowing and can thereby affect private sector borrowing costs. There is some evidence, mainly for developing countries, that government bond prices can influence corporate borrowing costs and thus have wider effects on activity. This relationship is less apparent in OECD countries. For example in Ireland, government bond yields have risen sharply whereas bond yields for similarly dated corporate bonds have been more stable.

At times, interest rate premia may also reflect private sector liabilities (particularly financial and to a lesser extent corporate), because of fears that the government may be forced to assume some of these liabilities, if they represent a systemic risk to the economy. The overall scale of private-sector liabilities varies significantly across countries, with the major differences reflecting financial sector liabilities (Figure 5.4). By comparison, non-financial corporate liabilities are more homogenous and are on average about one-third of the liabilities of financial corporations. Household financial liabilities represent an even more modest portion of private sector liabilities, though still exceed $100 \%$ of GDP in Denmark, Ireland, the Netherlands, Portugal, the United Kingdom and the United States. Against this background, an assessment of threats to fiscal consolidation may require some consideration of private sector liabilities with a judgment of whether the government may eventually assume some of them. 


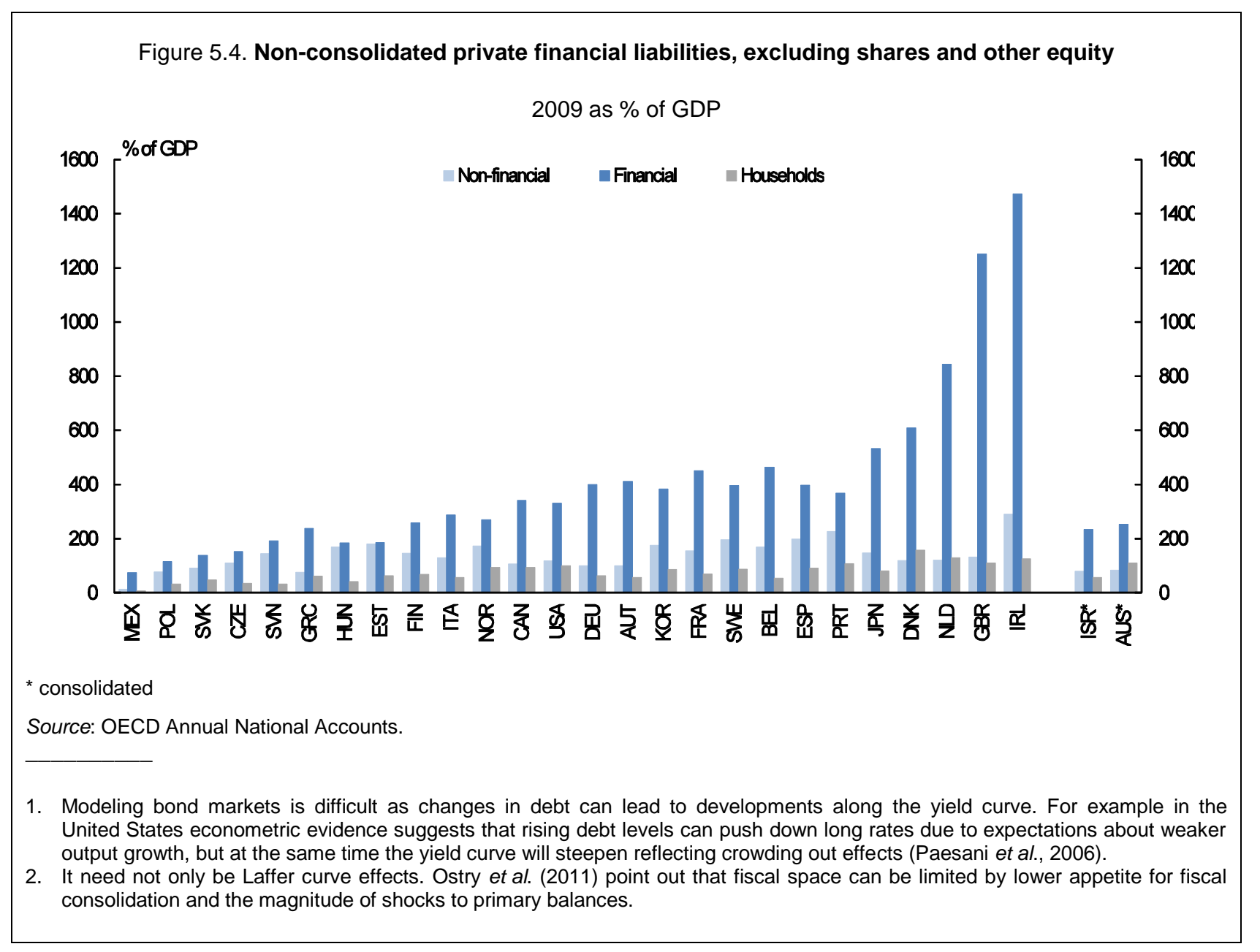

\section{Debt policies}

A final channel through which debt dynamics may be influenced is debt policies. There may be an opportunity inter alia to manage the maturity structure of debt to minimise servicing costs. An upward sloping yield curve may encourage reducing the average maturity of government bonds. However, this comes with risks, as shifts in market perceptions or liquidity premia can pass through quickly to the effective interest rate on government debt. In this context, the possible savings in debt servicing costs need to be balanced against the benefits from lengthening maturity and reducing exposure to the risk of unpredictable bond market movements. In particular, if fiscal shocks at high debt levels lead to large destabilising increases in risk premia, debt policies should attach a greater weight to reducing debt rollover risks.

Debt policies may also need to consider exposure to foreign borrowing. The share of externally held debt gives an indication of exposure to a sudden drying up of liquidity and changes in liquidity premia (Figure 5.5). Countries such as Austria, France, Finland and Iceland are relatively exposed to non-resident financing, though the debt load in Finland is comparatively modest. Such exposure need not be a significant risk if the debt is held in domestic currency and the country is not experiencing current account imbalances. In a few countries, notably Sweden, part of government debt is also denominated in foreign currency, which can create exposure to exchange rate risk. 
Figure 5.5. Government debt and share of debt held by non-residents

Total central government debt and share of marketable debt held by non-residents, 2009

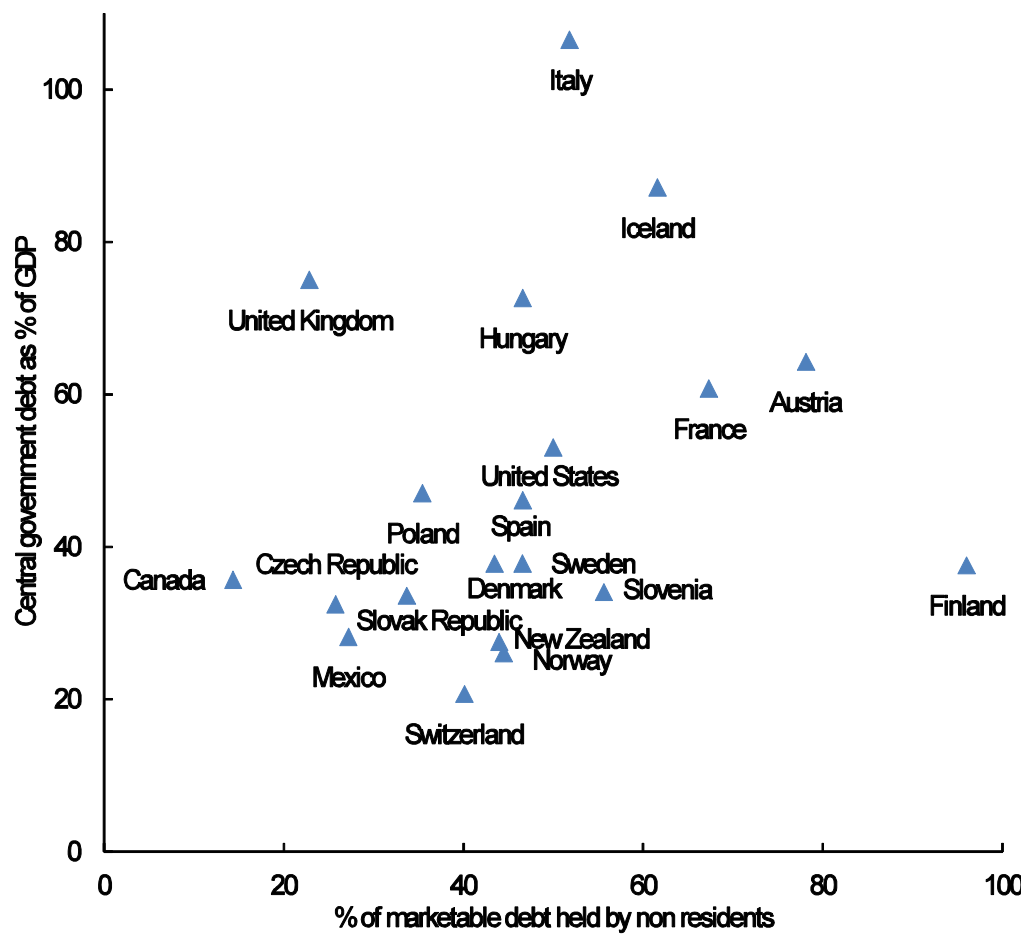

Note: Such data are only available for central government and not for general government.

Source: OECD Central Government Debt Database.

Extreme options are the restructuring of debt and default. This can become unavoidable for countries that are insolvent, but may also be necessary when short-term financing problems emerge or risk premia rise creating immense strains on otherwise solvent countries. The first option is to agree on a sovereign debt restructuring. Given that almost all sovereign debt is issued domestically, the domestic legal framework for an orderly restructuring and resolution should apply. In the absence of agreement on how best to restructure debt, a country may need to default. Default is likely to be very disruptive without forging prior agreement with creditors. A key concern with default (and also debt restructuring) is the potential for knock-on effects through the banking system. Banks in defaulting countries are likely to hold domestic assets, including as collateral, which may collapse in value. These banks would be put under severe financing pressure with governments likely to be unable to recapitalise them. Other costs would arise due to restricted access and facing higher risk premia when the country returns to international capital markets.

\section{The pace of consolidation and costs of delay}

The pace of consolidation needs to balance consolidation requirements with the effects of fiscal retrenchment on aggregate demand. Ideally, in the short term, the pace of consolidation should depend on the state of the public finances, the strength of the recovery, the ability of monetary policy to cushion the demand effects of fiscal tightening, and the need to signal a credible commitment to fiscal consolidation. However, there are significant uncertainties surrounding the state of the economy, which makes gauging the appropriate size and pace of consolidation complicated. The extent to which output will rebound and whether potential output growth has been affected by the crisis is one such issue. For example, the extent 
to which interest rates reflect higher risk premia and the extent of "scarring" of the unemployed during the crisis have implications for the level of output going forward. The precipitous drops in revenues should be reversed, but given the exuberance of asset prices prior to the crisis, there may need to be a reappraisal of underlying revenues. As such, fiscal consolidation needs to be implemented at a time when there is considerable uncertainty about both the underlying state of both the budgetary situation and the economy. These uncertainties would argue for a fiscal consolidation strategy that could be implemented flexibly, capable of adjusting the speed and intensity as new information becomes available. ${ }^{23}$ Moreover, it argues for the implementation of reforms that underpin credibility, but have little negative effect on demand in the short run, such as pension or health care reforms, which can also have large effects on long-term sustainability.

Fiscal gap calculations examine the consequences of delaying the fiscal consolidation. For this simulation a delay of two years was assumed, with the simulation extended by two years to 2052 so that the comparison with the baseline is for identical durations. ${ }^{24}$ The simulations show that for most countries a short delay has little effect on the necessary tightening (Figure 6.1). However, in a few cases, such as New Zealand, the United Kingdom, the United States and Japan, even a short delay would increase the fiscal gap visibly, requiring the underlying primary balance to be tightened permanently and additionally by over one-third of a percentage point of GDP. Another way to examine the consequences of delay is by phasing in the fiscal gap tightening more gradually. The example of the United States (Figure 6.2) shows that too gradual a tightening would allow adverse debt dynamics to develop so that further fiscal tightening would be required to bring debt down to prudent levels.

While delay can be costly for countries, particularly those running large deficits, the optimal rate of tightening will also depend on the state of the economy and how large a tightening it can bear. The impact of fiscal consolidation on economic activity will depend on the size of the fiscal multipliers and how rapidly they affect demand (Box 6.1). These vary across countries and type of fiscal policy instrument, in part, due to differences in economic structures and the state of the economy, such as the state of financial markets (Cogan et al., 2010). Furthermore, simultaneous fiscal tightening across countries may have larger effects. Typically, the magnitude of multipliers is assessed to be in the range of $1 / 2$ to 1 for government spending and somewhat lower for taxes. The differences in multipliers across instruments suggest that the sequencing of fiscal consolidations should start with tax increases before cutting government spending, though political economy considerations may suggest otherwise. The timing and pace of consolidation will also be affected by the ability of monetary policy to offset contractionary impacts. With policy rates low in many countries, and the zero lower bound still an important constraint, monetary policy is unlikely to be able to offer much support, arguing for a gradual phasing in of consolidation measures, particularly in the euro area (Box 6.2). As economies recover, monetary policy is less likely to be constrained by the zero bound and thus the pace of consolidation could be increased.

23. For example, more uncertainty about the strength of underlying revenues (either as a result of uncertainty about the state of the cycle or how much asset-price related revenues will recover) would suggest that consolidation efforts should place less weight on their possible recovery, at least initially.

24. The model was extended assuming that GDP growth was purely driven by productivity growth in the final two years of the simulation. 
Figure 6.1. The effect of delaying fiscal tightening on fiscal gaps

Change in the underlying primary balance needed to bring gross financial liabilities to $50 \%$ of GDP in 2050 or 2052

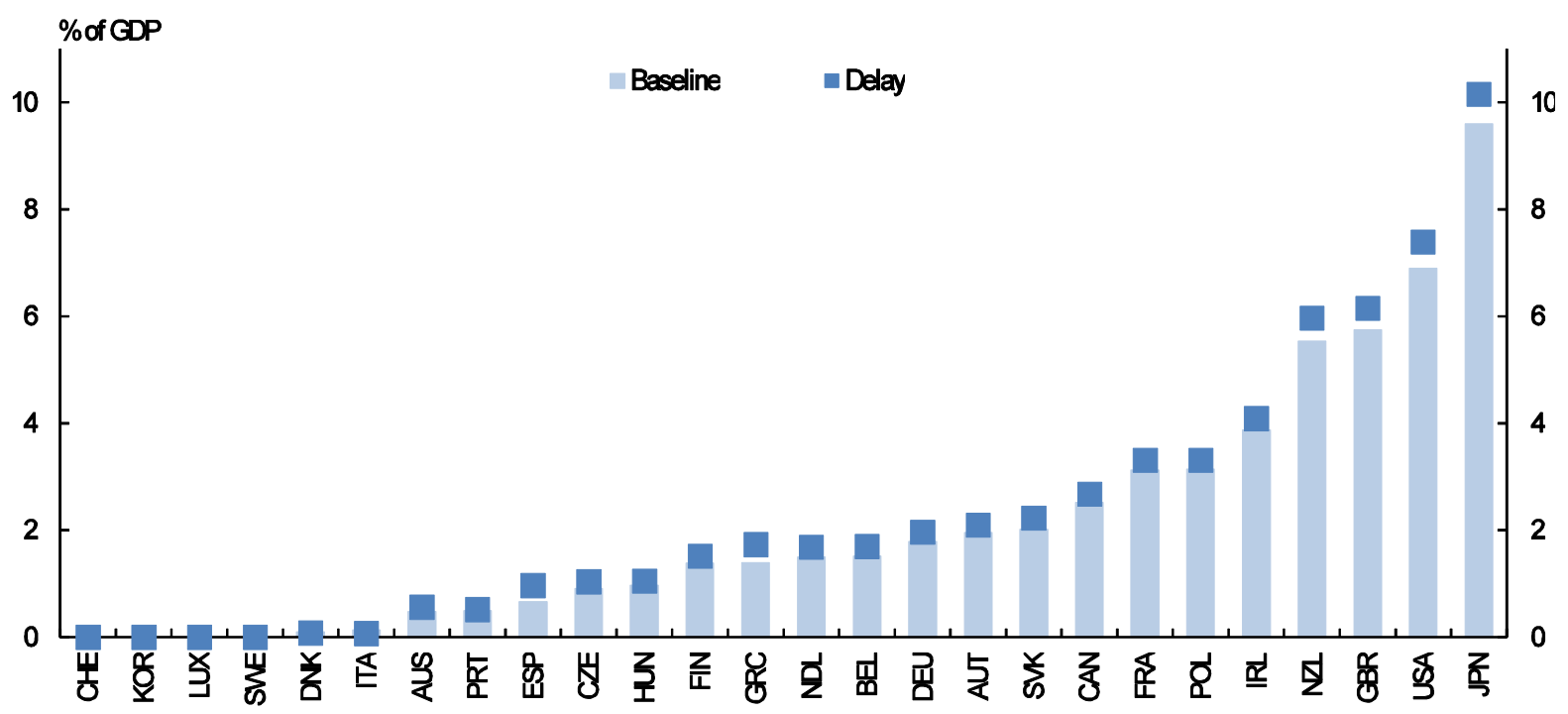

Note: The terminal debt target in the baseline is for 2050. In the delay simulations the fiscal tightening is delayed by two years and the terminal debt target is set for 2052.

Figure 6.2. The pace of fiscal tightening

Evolution of gross financial liabilities for the United States when the underlying primary balance is tightened so that debt is $50 \%$ of GDP in 2050 and the consequences of phasing in the same tightening more gradually

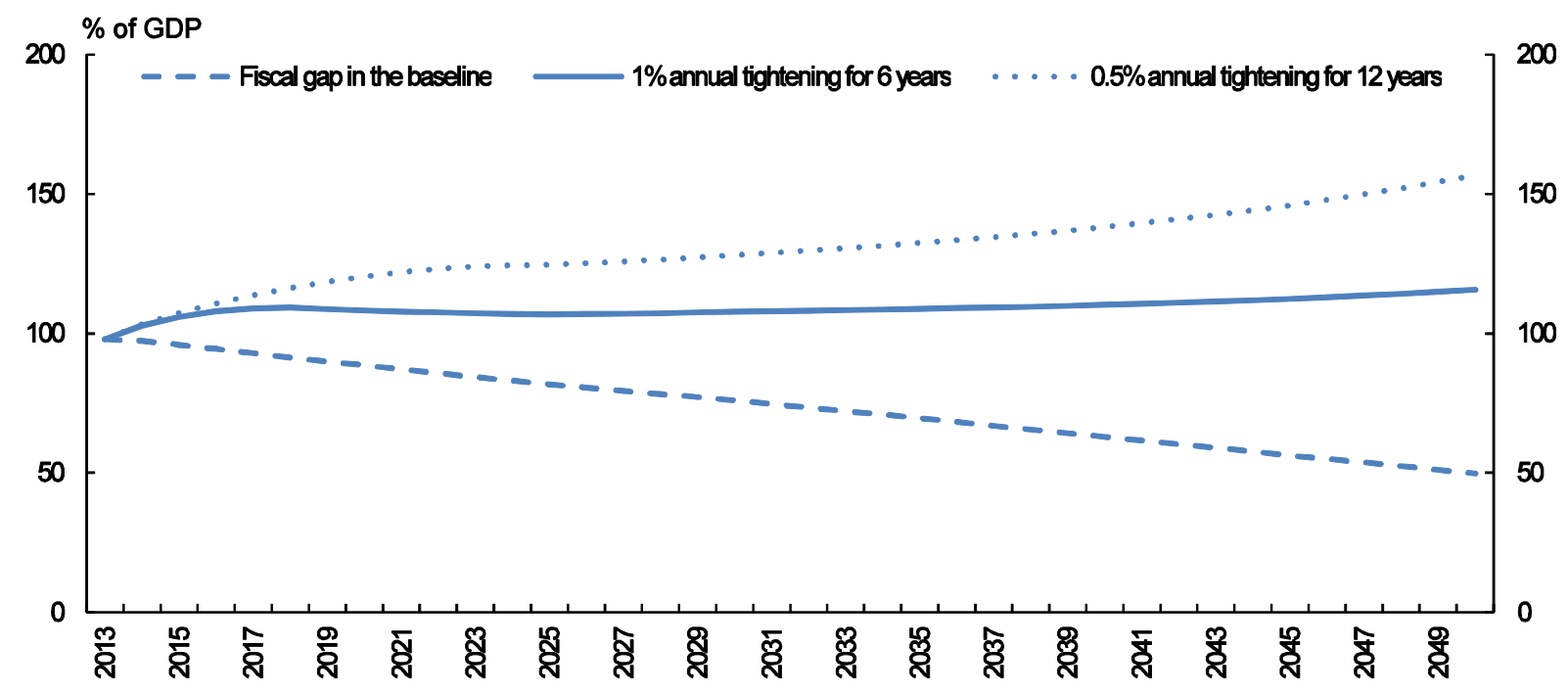




\section{Box 6.1. Fiscal policy multipliers}

The empirical research on the size of fiscal policy multipliers is voluminous and far from settled. A wide range of factors could potentially influence the effect of fiscal consolidation on activity. These include some considerations that may make a difference when considering the withdrawal of stimulus and a fiscal tightening to ensure longer-term fiscal sustainability.

- Multipliers may change in potency due to the state of the economy. In particular, during a recession, when the output gap is negative, expansionary spending is less likely to crowd out private consumption or investment (Auerbach and Gorodnichenko, 2010). Furthermore, when the zero interest rate bound is no longer a constraint, monetary policy could respond to fiscal contraction and thus crowd in private demand (Christiano et al., 2009; Woodford, 2010). However, any monetary policy response is complicated by the inherent uncertainty concerning how large output gaps are and how rapidly they are closing. At least in the short run, while interest rates are close to the zero bound, the contractionary effects of fiscal consolidation are likely to be stronger. Within Europe, the situation is more complex due to the differences in monetary conditions across countries within the euro area, with countries, such as Greece, Ireland, Portugal and Spain facing high interest rates, while demand is weak.

- Whether a fiscal policy change is permanent or temporary can affect the size of the multiplier. For example, some of the pessimism in the estimates of the effects of fiscal stimulus reported in Cogan et al. (2010) derives from the assumption of permanent policy changes. Woodford (2010) shows that for temporary policy changes multipliers can be larger. If temporary stimulus is credibly linked to subsequent consolidation, this can crowd in private spending in the short term (Corsetti et al., 2010).

- Expectations may have an effect through private saving reactions to fiscal policy. Recent OECD work assessing "Ricardian equivalence" suggests that the public-private saving offset becomes larger at high government debt levels (Röhn, 2010). These results suggest that at the current high level of government debt in many countries there may be a less contractionary effect from pursuing fiscal consolidation. A fiscal consolidation strategy that includes credible cuts in the future would lower long-term rates immediately and provide some stimulus. While such an effect is unlikely to give much support in countries with very low bond yields, it could be more important for those facing greater market pressure.

- A higher marginal propensity to consume out of current income by credit-constrained households can lead to a sharper contraction. The potency of fiscal policy may also rise if collateral constraints limit access to financial markets (Roeger and in't Veld, 2010). Financial market recovery may reduce the impact of these features, thus diminishing the size of multipliers during the consolidation period. Röhn (2010) found a related effect: private saving offsets are stronger when financial markets are more developed. This militates for swift action on financial market repair where there are still considerable problems.

One strand of the empirical literature has argued that under certain circumstances fiscal consolidations can have non-Keynesian effects leading to so-called expansionary fiscal contractions (Giavazzi and Pagano, 1990). More recently, some authors have questioned the empirical approach often adopted. Guajardo et al. (2010), for example, examined the use of changes in cyclically-adjusted primary balances to identify fiscal consolidation episodes. If consolidation episodes fail relatively quickly the sample will only capture successful consolidations leading to a bias. If instead consolidation episodes are based on stated intentions by governments, they found that fiscal consolidations are typically contractionary.

Whether fiscal consolidation is exogenous to growth has also been questioned. If consolidations are typically initiated when growth is picking up, the finding of consolidation episodes being correlated with stronger growth would merely reflect that and not imply causality. Once this endogeneity is taken into account, the episodes based on movements in cyclically-adjusted primary balances are also typically contractionary (Hernandez De Cos and MoralBenito, 2011).

From another perspective, the correlation between the underlying primary balance and short-term growth is arguably more appropriate for assessing short-term sustainability pressures, where the counterfactual may be a severe economic dislocation. If instead the concern is longer-term sustainability, pension reforms or limits on the inflow into disability rolls may only have a small short-term impact on budget balances, but a large impact on long-run sustainability. 


\section{Box 6.2. Consolidation in the euro area}

The main themes in this paper concern the appropriate pace of fiscal tightening, the choice of instruments and the long-term aim of consolidation. Membership of the euro area has implications for all three themes.

The desirable pace of consolidation is influenced by fiscal policy being set at the national level, while monetary policy being set by the European Central Bank. The appropriate monetary policy for the area as a whole tends to be out of line with the needs of the individual countries, especially the smaller ones. Countries with a large output gap face downward pressure on inflation, which raises the real interest rate and depresses output further. Moreover, intra-euro area real exchange rate adjustment at the individual country level tends to be slow, especially at low rates of inflation. In addition, countries where domestic absorption jumped during the good times due to low real interest rates may experience the reverse process during consolidation. For the smaller more open economies, fiscal consolidation may thus incur large output losses at a time of considerable economic weakness.

The appropriate choice of instrument is influenced by the need for a real exchange rate adjustment. Structural reforms that can hold down relative wages and costs can help the adjustment process. However, labour markets in the euro area countries do not provide much wage flexibility, while labour mobility tends to be low. On the fiscal side, developments in public sector wages can influence private sector wage setting, but there are limits to the extent public sector wages can be squeezed. Moreover, tax hikes can potentially raise costs and undermine competitiveness thereby intensifying and prolonging the necessary adjustment.

The long-term aim of fiscal consolidation is also affected by the allocation of monetary and fiscal policy. Without a nominal exchange rate that could help the adjustment process, debt in some respects resembles debt held in foreign currency. Compounding this effect, investors who change their risk assessment of a particular country due to the state of fiscal policy may switch to another euro-denominated asset and thereby increase liquidity risk. Given these factors, countries may wish to hold a lower debt stock when weighing the costs and benefits of debt. Aiming at a low debt level in the long run would also provide a greater cushion to attenuate a sharp fall in economic activity in the absence of monetary policy levers.

To explore the potential importance of different consolidation strategies a number of simulations were run using the NiGEM macro-econometric model (Barrell et al., 2012). In the model, some key differences across countries include the size of the multipliers. The multipliers in the model tend to be largest for government consumption, whereas tax impulses tend to have lower multipliers than spending. Differences across countries are largely related to the openness of the economy, the degree of dependence of consumption on current income and also the flexibility of the economy. Importantly for a fiscal consolidation, the short-term multipliers are lower for a permanent adjustment.

A first set of simulations examines consolidation programmes announced for the period 2010-12. The simulations assume financial markets are forward looking, consumers are myopic, all consolidation measures are permanent and monetary policy targets inflation and a nominal aggregate, the stock of money. In the first set of simulations, the model assumes unilateral action by governments. The results reveal that the expected impact on Greece is substantial, with a cumulative reduction in GDP of over 6\% of GDP (Figure 6.3). Other substantial impacts on output are projected by the model in Ireland, Portugal, Spain and the United Kingdom. A further insight from the simulations arises when comparing different assumptions about expectations. When agents are forward-looking which is equivalent to assuming that policies are credible, the negative multiplier effects are smaller than when compared with scenarios when agents have myopic expectations. Recent reforms to fiscal frameworks (see below) seek to enhance credibility, which may reduce the adverse impact on aggregate demand in the short run. 
Figure 6.3. Impact of announced fiscal consolidation on GDP

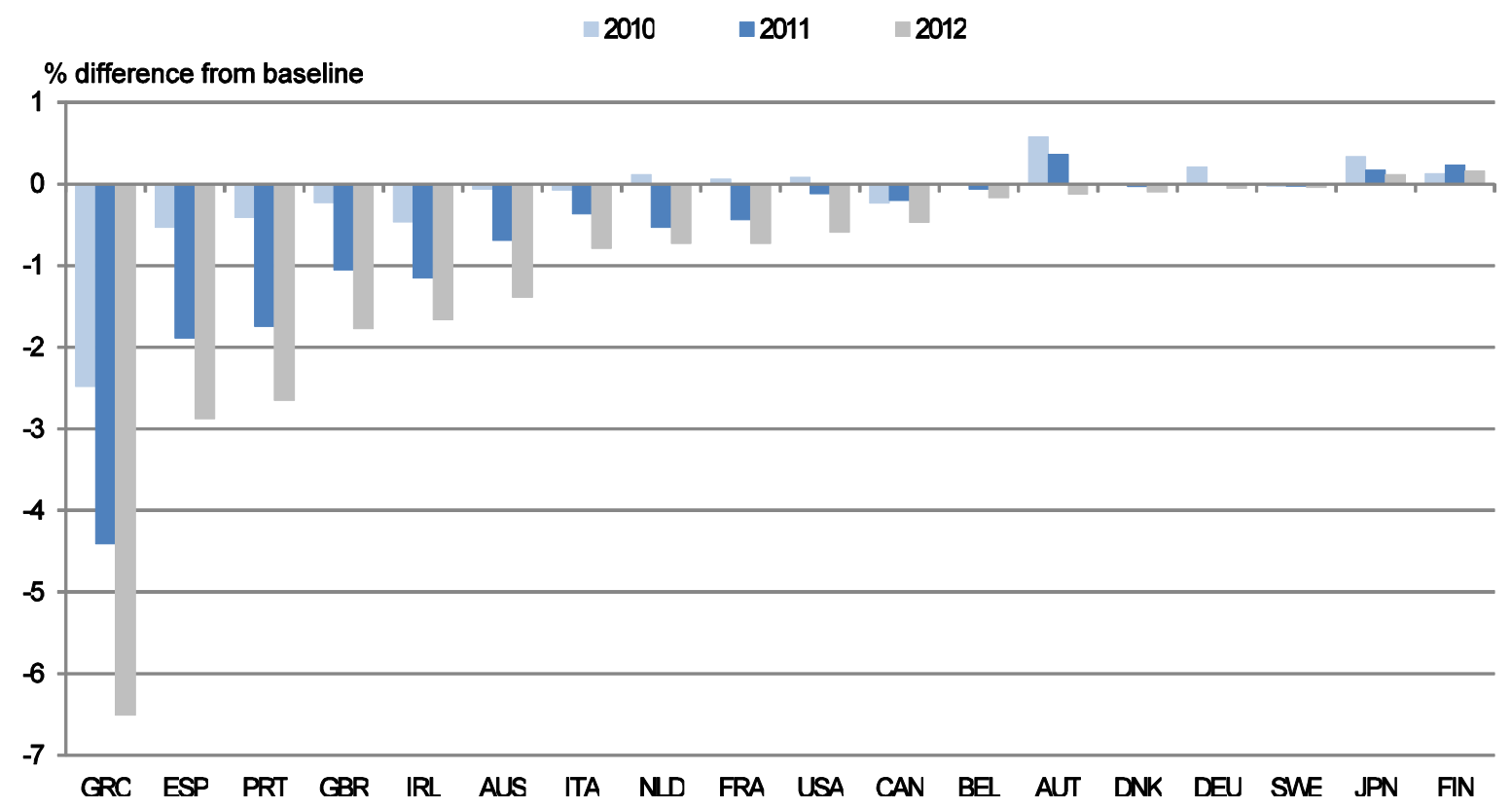

Note: Assumptions include financial markets are forward looking, consumers are myopic, all consolidation measures are permanent and monetary policy targets inflation and the stock of money.

An unusual aspect of current consolidation efforts is how widespread they are. Unlike past experience, fiscal consolidation is needed in almost all OECD countries simultaneously. In principle, simultaneous tightening intensifies the short-term contractionary impulse by reducing trade flows. The international dimension is also important as consolidation has implications for exchange rates. Within the euro area, the picture is more nuanced: while real exchange rates still matter, changing relative prices is tough and likely to be a drawn out process. In such cases, the structure of the consolidation package can become important. In the NiGEM simulations, the impact of simultaneous consolidation across countries differs from unilateral action as the impact of trade spillovers from fiscal contractions, exchange rate effects and the downward pressure on interest rates can either magnify or reduce the contractionary impulse (Figure 16 in Barrell et al., 2012).

Additional simulations examine the consolidation needs beyond 2012. In these simulations, both Japan and the United States are assumed to implement significant consolidations such that the deficit falls to $1.5 \%$ of GDP by 2020 . The simulations further examine different paces of consolidation. The results from these simulations suggest that GDP will return to baseline in around 8 years for permanent adjustment. Furthermore, adopting a faster pace of consolidation appears to pay for itself after three years, with output rising above that of the slower consolidation paths from that point, despite a sharper initial contraction. In addition, the simulations reveal that the euro area would stand to benefit somewhat from the United States and Japan beginning to consolidate in earnest through lower long-term interest rates.

Given high government debt-to-GDP ratios, some countries run the risk of unsustainable debt dynamics developing, especially if financing costs spike because financial market participants believe that consolidation efforts lack credibility. Thus, in countries which are particularly exposed to a financial market reaction the extent of consolidation may need to be larger and the pace faster than may be optimal if the main concern was the strength of the recovery. While interest rates on government debt remain relatively low in many countries, debt levels in the wake of the crisis are significantly higher, putting upward pressure on borrowing costs. When interest rates are linked to government debt levels, this can tilt the case towards earlier consolidation. Even moderate delays may incur high costs with the development of 
particularly adverse debt dynamics (Corsetti et al., 2011). ${ }^{25}$ On average for the OECD, interest payments accounted for around $2.5 \%$ of GDP in 2007, but higher debt levels coupled with a normalisation of interest rates could push up interest payments to over 4\% of GDP in 2026 (OECD, 2011e).

In order to examine the consequences of higher effective interest rates on government debt fiscal gap simulations incorporate an immediate increase in borrowing costs of 50 and 100 basis points to examine the consequences on the fiscal gap as well as debt levels in the absence of corrective action (Table 6.1). Simulations also consider the effect if there is no risk premium on the level of government debt. No other changes to the baseline model were assumed. Given these assumptions, the countries where the fiscal gap is most sensitive to higher effective interest rates are Japan, Greece, Italy, Ireland, Portugal and the United States. ${ }^{26}$ These countries would benefit from rapid fiscal consolidation as borrowing costs are affected by premia on the size of government debt. On the other hand, countries where debt loads are low or bond yields do not reflect risk premia the costs of delay are likely to be smaller. The flip side is that these countries will not enjoy the reduction in borrowing costs once debt begins to fall.

Table 6.1. Increases in borrowing costs

\begin{tabular}{|c|c|c|c|c|c|c|c|c|c|}
\hline \multirow[b]{4}{*}{ Auctrolin } & \multicolumn{5}{|c|}{ Fiscal gap, \% of GDP } & \multicolumn{4}{|c|}{$\begin{array}{c}\text { Gross financial liabilities increase by } 2020 \text {, } \\
\% \text { of GDP }\end{array}$} \\
\hline & \multicolumn{3}{|c|}{ With risk premia } & \multicolumn{2}{|c|}{ Without risk premia } & \multicolumn{2}{|c|}{ With risk premia } & \multicolumn{2}{|c|}{ Without risk premia } \\
\hline & Baseline & $+50 \mathrm{bp}$ & $+100 \mathrm{bp}$ & $+50 \mathrm{bp}$ & $+100 \mathrm{bp}$ & $+50 \mathrm{bp}$ & $+100 \mathrm{bp}$ & $+50 \mathrm{bp}$ & $+100 \mathrm{bp}$ \\
\hline & 0.5 & 0.7 & 0.8 & 0.7 & 0.8 & 1.4 & 2.9 & 1.0 & 3.0 \\
\hline Austria & 2.0 & 2.3 & 2.6 & 2.4 & 2.7 & 3.5 & 7.0 & 3.3 & 6.8 \\
\hline Belgium & 1.5 & 1.9 & 2.3 & 1.9 & 2.3 & 4.1 & 8.3 & 3.9 & 7.9 \\
\hline Canada & 2.5 & 2.9 & 3.2 & 2.9 & 3.2 & 3.9 & 7.9 & 3.7 & 7.5 \\
\hline $\begin{array}{l}\text { Czech } \\
\text { Republic }\end{array}$ & 0.9 & 1.2 & 1.4 & 1.3 & 1.5 & 2.2 & 4.5 & 2.2 & 4.5 \\
\hline Denmark & 0.1 & 0.4 & 0.7 & 0.4 & 0.7 & 2.8 & 5.7 & 2.8 & 5.7 \\
\hline Finland & 1.4 & 1.7 & 1.9 & 1.9 & 2.1 & 2.6 & 5.2 & 2.6 & 5.2 \\
\hline France & 3.1 & 3.5 & 3.9 & 3.9 & 4.3 & 4.3 & 8.8 & 4.2 & 8.5 \\
\hline Germany & 1.8 & 2.2 & 2.5 & 2.2 & 2.6 & 3.9 & 7.9 & 3.7 & 7.6 \\
\hline Greece & 1.4 & 2.0 & 2.6 & 2.2 & 2.8 & 6.6 & 13.5 & 6.2 & 12.6 \\
\hline Hungary & 1.0 & 1.3 & 1.7 & 1.6 & 1.9 & 3.8 & 7.8 & 3.7 & 7.5 \\
\hline Ireland & 3.9 & 4.3 & 4.8 & 4.8 & 5.3 & 5.3 & 10.8 & 5.0 & 10.2 \\
\hline Italy & 0.1 & 0.6 & 1.1 & 1.1 & 1.6 & 5.1 & 10.4 & 4.9 & 10.0 \\
\hline Japan & 9.6 & 10.3 & 11.0 & 10.7 & 11.3 & 9.2 & 18.7 & 9.0 & 18.2 \\
\hline Korea & 0.0 & 0.0 & 0.2 & 0.0 & 0.2 & 1.3 & 2.7 & 1.3 & 2.7 \\
\hline Luxembourg & 0.0 & 0.0 & 0.0 & 0.0 & 0.0 & 1.2 & 2.3 & 1.2 & 2.3 \\
\hline Netherlands & 1.5 & 1.8 & 2.1 & 2.0 & 2.3 & 3.3 & 6.7 & 3.2 & 6.5 \\
\hline New Zealand & 5.5 & 5.8 & 6.0 & 5.8 & 6.0 & 3.0 & 6.1 & 2.9 & 5.9 \\
\hline Poland & 3.1 & 3.4 & 3.7 & 3.8 & 4.0 & 3.2 & 6.4 & 3.2 & 6.3 \\
\hline Portugal & 0.5 & 0.9 & 1.4 & 1.2 & 1.6 & 4.6 & 9.4 & 4.4 & 9.0 \\
\hline $\begin{array}{l}\text { Slovak } \\
\text { Republic }\end{array}$ & 2.0 & 2.3 & 2.5 & 2.3 & 2.5 & 2.4 & 4.8 & 2.4 & 4.8 \\
\hline Spain & 0.7 & 0.9 & 1.2 & 1.1 & 1.4 & 2.8 & 5.7 & 2.8 & 5.7 \\
\hline Sweden & 0.0 & 0.0 & 0.0 & 0.0 & 0.0 & 1.5 & 3.0 & 1.5 & 3.0 \\
\hline Switzerland & 0.0 & 0.0 & 0.0 & 0.0 & 0.0 & 1.3 & 2.6 & 1.3 & 2.6 \\
\hline $\begin{array}{l}\text { United } \\
\text { Kingdom }\end{array}$ & 5.8 & 6.1 & 6.5 & 6.7 & 7.1 & 4.7 & 9.5 & 4.5 & 9.1 \\
\hline United States & 6.9 & 7.3 & 7.7 & 7.9 & 8.3 & 5.1 & 10.3 & 4.8 & 9.8 \\
\hline
\end{tabular}

Note: The debt increase is relative to the baseline simulation assuming no tightening of the underlying primary balance.

25. The danger of adverse debt dynamics developing depends on at least four factors: The sensitivity of the government's budget to output; the initial level of government debt; the sensitivity of the sovereign risk premium with respect to the level of debt, and the extent to which sovereign risk spills over to other sectors.

26. The increase in Japanese debt is relatively constrained, despite the high fiscal gap, due to the assumption of a low risk premium. 
When bond market uncertainty threatens to drive the pace of consolidation and potentially derail it, policies and institutions that commit government to fiscal probity have a potential role in creating additional fiscal space in the short run by allaying market concerns that fiscal tightening will occur in the future (these issues are discussed in section 8 ).

\section{Instruments for fiscal consolidation}

While stronger growth can play some role in controlling debt dynamics, given the scale of consolidation needs, consolidation will need to come largely from improvements in the primary balance, which is also under policy control. Drawing on Hagemann (2012), this section assesses first the potential contribution from spending and revenue instruments before developing a matrix for assessing different instruments against their potential to improve the primary balance as well as other policy objectives such as growth and distributional impacts.

\section{The balance between spending cuts and revenue increases}

Although the "optimal" size of government is not known, an accepted tenet of public finance is that beyond some level of revenue collection, the marginal net social costs - including the excess burden of taxation - of additional public expenditure increase more than proportionately with the additional taxation needed to finance spending. Against that background and given the current high level of public spending in many countries and the future spending pressures due to population ageing, the largest part of consolidation probably should consist of cuts in public spending. Since many countries rely on so-called tax expenditures for the pursuit of selected policy goals (e.g., home ownership), the reduction or elimination of base-eroding tax preferences will appear as revenue enhancements rather than spending cuts. In other cases where spending is low, there may be a case to put greater emphasis on revenue measures.

Evidence suggests that fiscal consolidations that favour reductions in current primary spending hold greater promise of durable deficit reduction than those that favour tax increases (Guichard et al., 2007; IMF, 2010 $a$ and Molnar 2012). One reason for this is that tax increases can lead to higher costs and prices, which may imply a short-run conflict with monetary policy objectives (Ahrend et al., 2006). However, the composition of a consolidation package and in particular the sequence of implementation of measures may also depend on the relative multiplier effects of spending and revenue measures, particularly when the economic recovery is fragile (see above).

In most OECD countries, however, fiscal consolidation will also entail revenue reforms. First, even a static revenue-neutral reform can improve economic performance through beneficial efficiency effects, in turn expanding the tax base in the long run (Johansson et al., 2011). Second, whereas many countries require fiscal reforms to restore long-run sustainability, some may require a front-loaded budgetary package that includes revenue measures that may yield faster deficit reduction or be politically easier than spending cuts. Third, where there is confidence that the marginal benefit of additional spending equals the marginal costs of a corresponding tax hike, a case can be made for a balance of spending cuts (including spending via tax expenditures) and revenue increases (OECD, 2010a). Finally, there can be scope for boosting revenue from taxes having favourable welfare effects (e.g., environmental levies).

\section{Consolidation has to be attentive to equity and other policy objectives}

A well-designed fiscal consolidation strategy needs to anticipate and minimise adverse effects on equity and other policy goals. The equity issues surrounding tax and transfer systems are discussed in Joumard and Pisu (2012). As social welfare functions differ across countries, first-best policies will reflect a different balance of efficiency, distributional, and other concerns. Where distributional impacts of 
consolidation policies are a high priority, offsetting measures to protect the poor will be needed. For instance, where fiscal consolidation might justify reduced subsidies for tertiary education, targeted support (e.g., means-tested student grants or subsidised loans) can help protect low-income students. ${ }^{27}$

\section{Instruments}

Many spending and revenue instruments are available to restore the sustainability of the public finances. Most of them involve trade-offs with other policy objectives, such as equity and growth. This section discusses a number of spending and revenue policy areas that may hold promise for fiscal consolidation efforts.

\section{Spending instruments}

Giving high priority to positive long-run growth impacts of spending largely rules out across-theboard cuts in public investment, though not ruling out savings through more thorough cost-benefit analysis. A number of areas of current spending, however, offer considerable promise of contributing both directly and indirectly (through favourable impacts on key drivers of growth) to consolidation. First, reforms can improve the efficiency of public programmes to produce significant budgetary savings without compromising outcomes. Second, a panoply of social transfers presents opportunities to reduce spending via improved incentives without harm to social protection.

\section{Improving efficiency of public spending}

Health care

Government interventions in countries' health care systems are pervasive throughout the OECD and reflect a number of policy objectives. Broadly recognised motivations for public involvement in health care include the existence of market failures arising from asymmetric information and adverse selection, as well as the desire to ensure that access to an adequate level of health care services is determined by need rather than solely by ability to pay. Concomitantly, governments devote considerable resources to health care. Indeed, the growth of health care spending poses serious challenges for all OECD countries. By 2007, public health care spending accounted for $6.4 \%$ of GDP spending in the OECD area, up from $5.5 \%$ of GDP in 1995, and on unchanged policies could rise by a further 3-6 percentage points of GDP by 2050 (OECD, $2010 \mathrm{c}$ ). While population ageing contributes to the growth of outlays, other factors dominate. In particular, the growth of outlays in excess of what would normally be expected from shifting demographics and real income growth - so-called "excess cost growth" - is attributable to both demand-increasing features of insurance systems, supply-side factors that prevent the most efficient pricing and delivery of care, and costraising technological innovations.

In the case of health care spending, higher levels of spending are not necessarily undesirable, but financing higher spending can create difficulties (Hall and Jones, 2007). Fiscal gap simulations indicate the possible pressure that may arise from this source. Two sets of health care spending projections are used, drawing on scenarios of health and long-term care spending for 2025 and 2050 (Oliveira-Martins and de la Maisonneuve, 2006). Changes in spending are phased in gradually so that spending to GDP ratios equal these estimates in 2025 and then 2050. As such, spending does not depend on the ageing profile over the projection horizon. The average projected increases in health and long-term care spending by 2050 are $3 \frac{1}{2}$ per cent of GDP in a low spending scenario and around $6 \%$ of GDP in a high spending one. As the

27. A key theme of the recent Mirrlees Review (2010) is that well-designed reforms are those that take full account of impacts on and changes in the whole tax and transfer system. This approach also underpinned the ongoing tax-transfer reform initiatives in Australia (Commonwealth of Australia, 2010). 
projected increases are relatively similar the impact on the fiscal gaps does not vary much, but exceeds over 1.5\% of GDP in Canada, the Czech Republic, Japan, New Zealand and Switzerland when greater cost pressures affect health spending (Figure 7.1). In some countries, the projected increases in long-term care are substantial, particularly for Finland, Ireland, Italy and Luxembourg, where they add over an additional percentage point of GDP to the fiscal gap.

Figure 7.1. Fiscal gaps with health and long-term care spending

Immediate rise in the underlying primary balance needed to bring gross financial liabilities to $50 \%$ of GDP in 2050

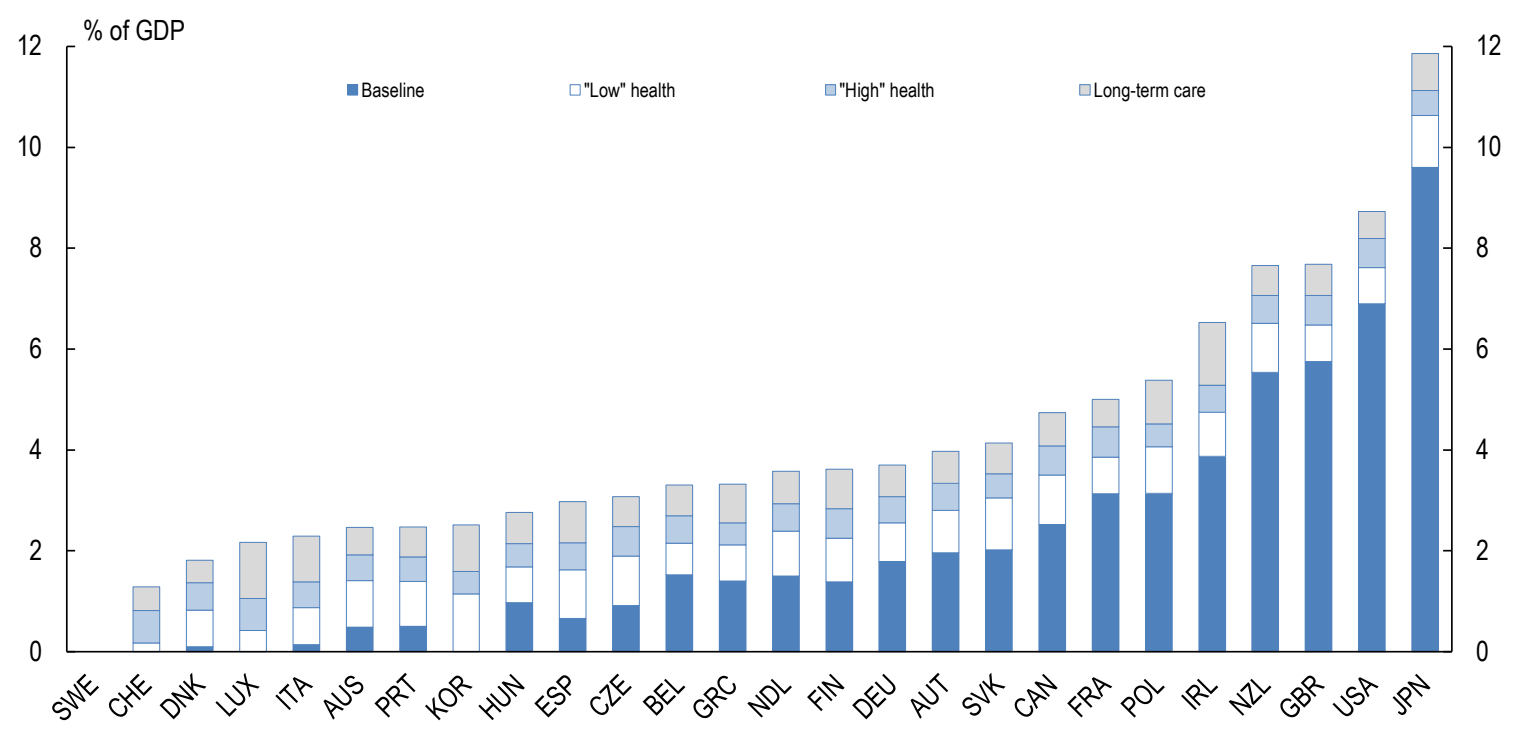

Note: "Low" health assumes policy action curbs health spending growth. "High" health is the additional cost pressure in the absence of these policy actions.

There exists a wide variety of institutional arrangements for health care financing and delivery throughout the OECD. Extensive research suggests there is no particular arrangement that performs systematically better than others, and cost containment strategies are therefore to some degree specific to a country's starting point, including its choice of health care model. That said, research suggests that in general, the most effective reforms include those that strengthen and broaden the role of market mechanisms, change reimbursement schemes (e.g., from fee-for-service to capitation or a mix of both), improve public management and control, and impose budget caps.

The potential budgetary savings of reforms are substantial. Joumard et al. (2010b) assessed the potential health gains from efficiency-raising reforms, defined as all countries achieving the same level of efficiency as the "best" performers in the OECD. Savings on the order of 2\% of 2017 GDP could be achieved on average $(\mathrm{OECD}, 2010 d)$. For some countries, the potential savings are substantially greater (Figure 7.2).

\section{Education}

Public support for education, in particular primary and secondary, is one of the pivotal functions of government in promoting equal opportunity and income growth. Governments spend substantial sums, averaging $5.2 \%$ of GDP, ranging from around $3 \frac{1}{2}$ per cent in Japan to close to $8 \%$ in Denmark (Figure 7.3). But educational systems are often replete with inefficiencies and improved efficiency could allow governments to achieve the same educational outcomes at lower cost. 
A host of reform options are available for raising efficiency, and the configuration would naturally differ across countries. Notwithstanding, the most promising reforms tend to be those that make educational systems more responsive to educational needs through, for instance, more decentralised management of budgets, and allowing competitive pressures to impact educational supply and demand choices (Gonand et al., 2007). Sutherland et al. (2007) estimated that adoption of best practice in primary and secondary education could yield savings of about 1\% of GDP in countries whose educational system underperforms relative to the best performers.

Figure 7.2. Budgetary savings from improved efficiency in health care systems

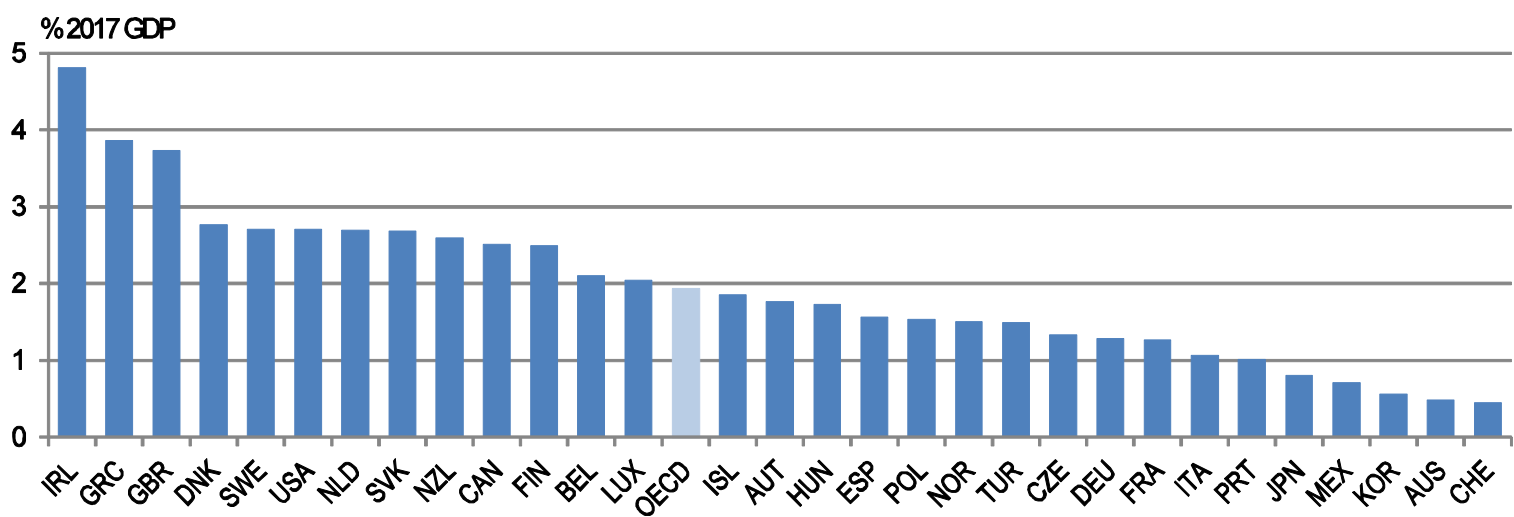

Note: Potential savings represent the difference between a no-reform scenario and a scenario where countries would exploit efficiency gains. The no-reform scenario assumes that between 2007 and 2017 life expectancy and spending increase at the same pace as over the previous 10 years and that the mix between public and private spending remains constant over time.

Source: Joumard, I., P. Hoeller, C. André and C. Nicq (2010b), Health Care Systems: Efficiency and Policy Settings, OECD Publishing.

Figure 7.3. Public and private spending on educational institutions

2007

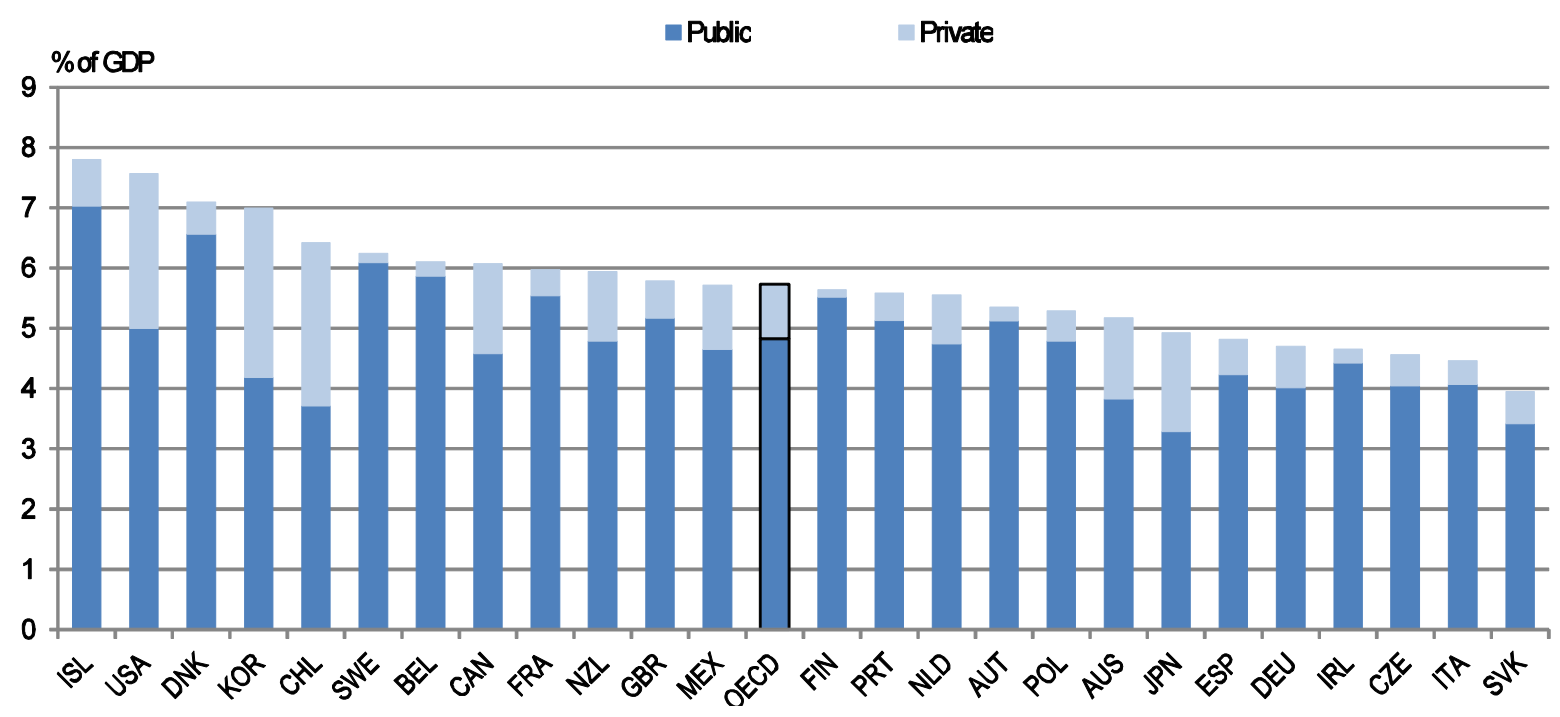

Source: OECD (2010c), Education at a Glance 2010, Table B2.4.

Close to a quarter of public spending on education is to support tertiary education, including tuitionfree attendance in many countries, especially in continental Europe. As a large share of returns to publiclyfunded tertiary education accrue to individuals rather than to society (Blöndal et al., 2002), continued 
generous public support for higher education can be questioned, given the greater prevalence of tertiary education among middle and upper income households. The introduction or increase of tuition fees may improve educational outcomes, by making schools more responsive to market demands, with long-term gains to human capital, the quality of labour supply, the economy's rate of potential growth, and overall fairness.

Other public services

While important gains can be achieved through a host of management, governance and pay reforms, as well as through the innovative use of modern technologies, reducing the public sector wage bill is a key candidate for fiscal consolidation in many countries. On average, the general government wage bill is close to $10 \%$ of GDP and accounts for roughly one quarter of overall spending. While a skilled and adequately staffed workforce is a sine qua non of effective government, and competitive pay is essential, there are countries where a large public-private sector wage gap has developed over time. In such countries, governments perforce need to realign pay relativities through sustained public sector wage restraint. With private sector wage growth having slowed during the recent crisis, many governments may also want to impose a period of public sector wage restraint. Comparing public and private remuneration levels poses serious challenges, however, and requires valuation of working conditions and non-wage remuneration, such as defined benefit pension schemes. The ultimate test of adequacy is likely to be the difficulty or ease of recruitment into and retention in the civil service. From this perspective, budgetary savings achievable through reductions in the government wage bill should best be the outcome of a thorough review rather than across-the-board or arbitrary cuts in pay or size of the workforce.

The scope for achieving savings on remuneration is difficult to determine, although international comparisons can give some indication. Some evidence suggests that the public sector wage bill is relatively high given the level of public employment in Greece, Portugal, Italy and Ireland (Barbier-Gauchard et al., 2010). And, indeed, Ireland and Hungary have demonstrated recently that substantial cuts in public sector wages can be implemented if there is an urgent need for consolidation and a strong case arising from unjustified public-private pay relativities.

\section{Reforming transfers and income support}

OECD governments devote considerable amounts of public funds to social transfers. These include contributory benefits (e.g., social insurance) and non-contributory payments such as family benefits. Gross public spending on transfers was on average just under 14\% of GDP in 2007, ranging from below 5\% in Korea and Mexico to over 21\% in France (Figure 7.4). ${ }^{28}$ The bulk of spending is for old age and survivor pensions, but outlays on sickness and disability payments and on family benefits are also significant (Table 7.1). By their sheer volume, social transfers need to be reviewed in the context of fiscal consolidation, although mobilising political support will in many countries be a challenge, even if about $45 \%$ of transfers on average go to households in the upper half of the income distribution (Whiteford, 2009). In some cases, this reflects to no small extent the fact that many programmes are not well targeted at social concerns per se, though this can also be the outcome of how countries view the desirability of targeting.

28. The dispersion across countries is narrowed markedly, however, when account is taken of the impact of tax systems (via "claw backs" through direct and indirect taxation of benefits, the provision of family benefits provided through tax credits and favourable tax treatment in support of social initiatives), and, to a lesser degree, of mandatory private social interventions (Adema and Ladaique, 2009). 
Figure 7.4. Non-health social transfers in OECD countries

2007

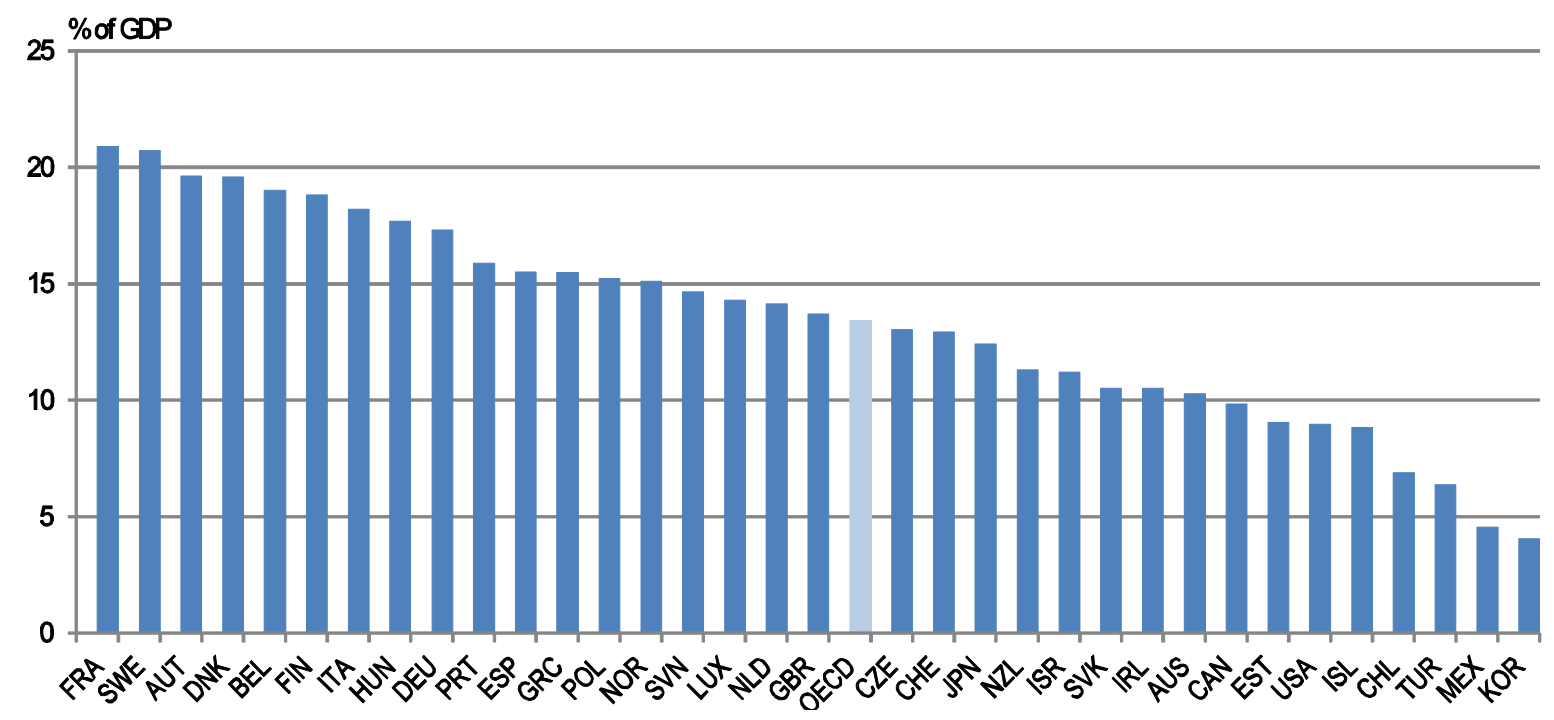

Source: OECD SOCX Database.

Table 7.1. Growth and distribution of non-health social spending

In per cent of GDP

\begin{tabular}{lrrrr}
\hline & 1980 & 1990 & 2000 & 2007 \\
\cline { 2 - 5 } Old age & 5.1 & 5.9 & 6.5 & 6.4 \\
Survivors & 1.0 & 0.8 & 0.9 & 1.0 \\
Incapacity related & 2.3 & 2.3 & 2.3 & 2.1 \\
Family & 1.6 & 1.6 & 1.9 & 1.9 \\
Other & 1.2 & 2.2 & 2.2 & 1.9 \\
Total & 11.1 & 12.9 & 13.6 & 13.4 \\
\hline Source: OECD SOCEXP Database & & & &
\end{tabular}

Pension reforms can slow spending growth and boost elderly employment

Despite the reforms introduced during the past couple of decades, many OECD countries continue to face looming fiscal pressures related to the ongoing ageing of their populations. On average in the OECD, public pension spending is projected to increase from 8.4\% of GDP in 2010 to $11.4 \%$ in 2050 (OECD, $2011 a$ ), with substantially larger increases in several countries. The implications of these increases on public finances in the absence of reform can be assessed with fiscal gaps. ${ }^{29}$ The simulations do not take into account taxes on private occupational pension schemes, which in some cases could boost revenues

29. The path of projected public pension spending is phased in so that the spending profile follows the profile of the old-age dependency ratio. This is a simplification in the absence of modelling all countries' pension systems. However, a comparison of the profile of public pension spending with other estimates shows that the profiles are usually quite similar and this seems therefore a reasonable approximation. The pension projections are based on OECD (2011a), which draw on national estimates. For Greece and Spain, the change in pension spending is based on estimates of the impact of reforms in 2010 and a change in the law in 2011, respectively. For the United States, estimates from CBO (2011) are used. For most European countries, public sector occupational schemes are included. This is not the case for Canada and Japan. 
significantly. ${ }^{30}$ Including pension spending alters the fiscal gaps for many countries radically relative to the baseline scenario (Figure 7.5). The fiscal gaps of the countries facing the largest pension problems, such as Luxembourg, Belgium and the Netherlands underscore that meeting these challenges would be better addressed by reform rather than pre-saving. In some cases, such as Greece and Spain, reforms to the pension systems in 2010 address the pressures emanating from this source. In Sweden and Poland, however, maintaining its current underlying fiscal position combined with the implications of the notionally-defined contribution pension system means that no additional or less tightening is required to meet a gross financial liabilities debt target of 50\% of GDP in 2050 .

\section{Figure 7.5. Fiscal gaps with pension spending}

Change in underlying primary balance needed to bring gross financial liabilities to $50 \%$ of GDP in 2050

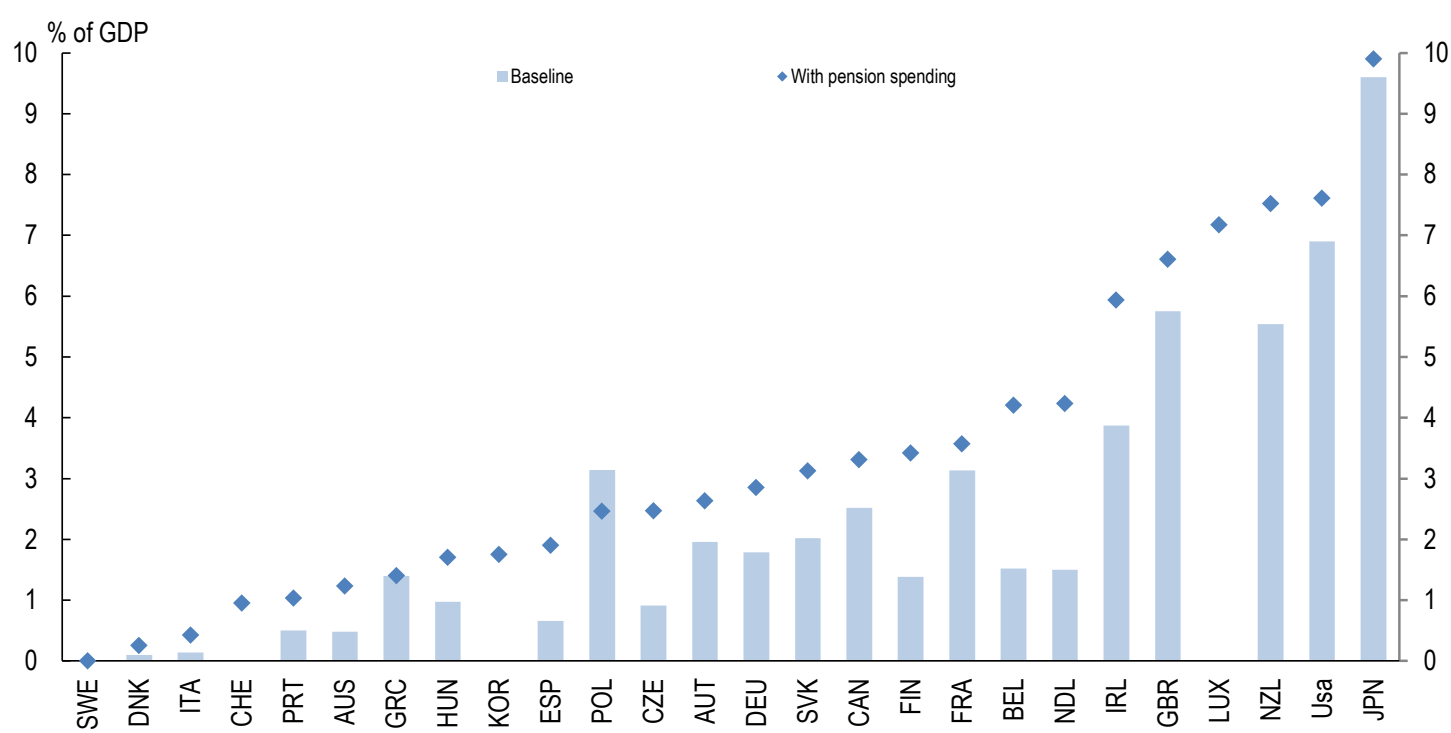

Note: The change is from the underlying primary balance projected for 2012 .

The need for structural reform is even more apparent when different spending pressures are combined. In the simulations that assess the increases of pension and health and long-term care spending together, the evolution of debt in some countries suggests that the fiscal tightening will not be sufficient to ensure sustainability beyond the terminal date used in these simulations (Figure 7.6). In these cases, the fiscal gap implies an under-shoot of the debt target before the end of the simulation. Without reform, spending pressures would continue to grow beyond the end of the simulation period and thus represents a continued long-term threat to public finances. To some extent, for pensions, the demographic transition will eventually see the acute spending pressure abate though pressure will continue to mount if life expectancy continues to increase and retirement ages do not adjust. ${ }^{31}$

While much of recent spending growth in these areas has been due to population ageing per se (due mostly to falling birth rates in the past), spending increases have also been driven partly by a progressively

30. Antolin et al. (2004) for example estimate that accompanying rising revenues on withdrawal would lead to net fiscal revenue for "exempt, exempt, taxed" (EET) schemes to become less negative and in some cases sharply positive by 2050 .

31. For example, in the case of Spain the combined effects of recent pension reforms and projected declines in the old age dependence ratio beyond 2050 should contribute to a decline in pension spending as a share of GDP. 
lower effective retirement age and longer lives. With social contribution rates and associated marginal tax wedges on labour already high in many countries (notably in continental Europe), most governments recognise the need to slow the growth of outlays through a variety of parametric changes. Reforms aimed at delaying pension receipt (e.g., raising the statutory retirement age together with increased penalties/bonuses for early/later retirement, and indexing the statutory retirement age to increases in life expectancy) can not only slow the growth of outlays, but can also boost the labour force participation of elderly workers. Bouis and Duval (2011) find that pension reforms that improve incentives to remain employed and delay retirement by two years could potentially boost overall employment rates by $1 \frac{1}{2} 2$ per cent after 10 years, with positive feed-through impacts on potential growth and the tax base.

\section{Figure 7.6. Debt evolution with pension, health and long-term care spending}

Gross financial liabilities, 2013-50
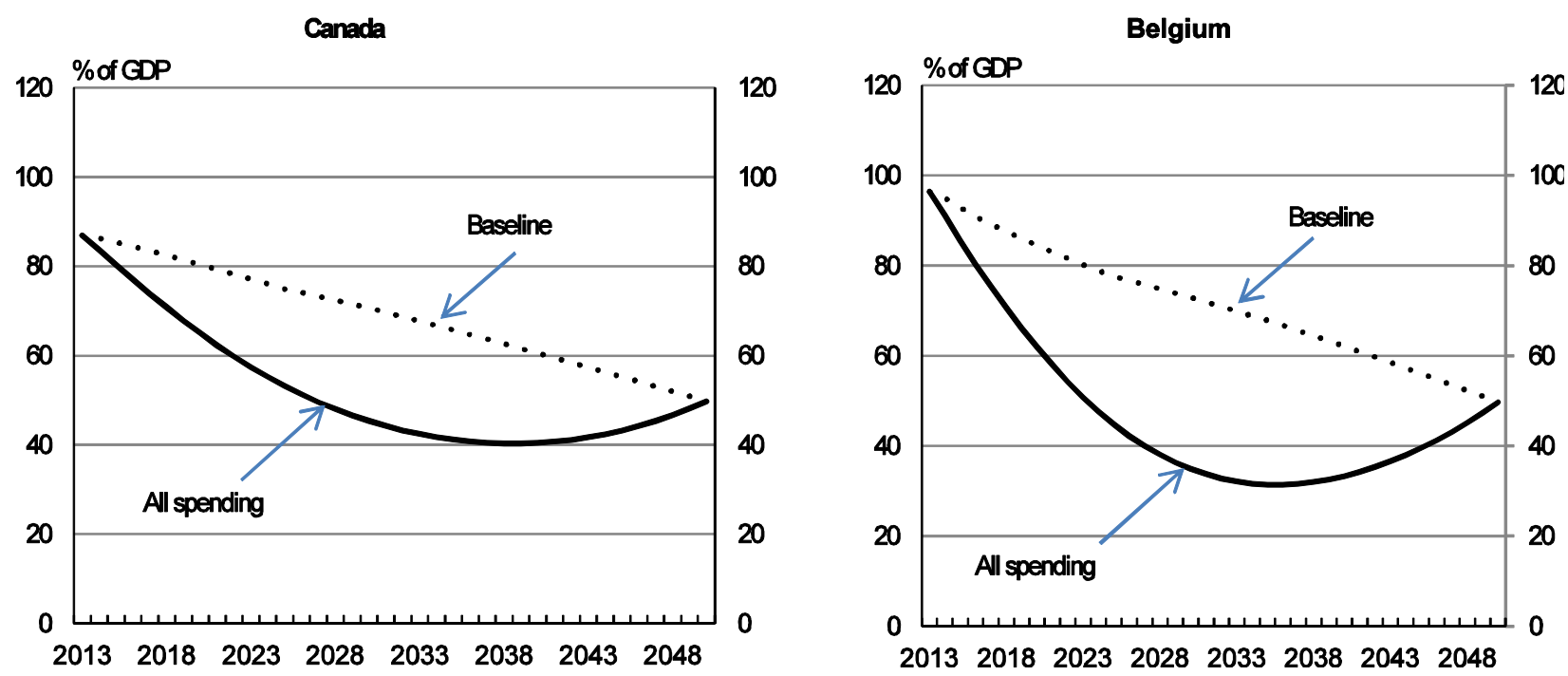

Note: The figures show the evolution of gross financial liabilities for the fiscal tightening in the baseline fiscal gap simulation and for the fiscal tightening to meet a scenario with pension, health and long-term care spending needed to meet the $50 \%$ of GDP debt target in 2050.

In fiscal gap simulations that explore the consequences of raising the retirement age, the effective retirement age is gradually increased so that by 2050 individuals are working five years longer than in the baseline. $^{32}$ In some cases, this will reflect policies already in place to increase retirement ages. The impact of delaying retirement can be considerable. In countries where fiscal gaps are high largely due to the consequences of pension spending, such as Belgium, Luxembourg and the Netherland, the reduction in the fiscal gap can be several per cent of GDP (Figure 7.7). Most of the effect arises due to the change in claimant numbers for pensions rather than the effect on output (Merola and Sutherland, 2012). This underscores the potential importance of pension reform in restoring fiscal sustainability. ${ }^{33}$

32. While the labour force expands with the gradual increase, to maintain simplicity unemployment rates and participation rates of the labour force as a whole are assumed to remain unchanged.

33. The effects of reforms to the pension system can be sizeable. In May 2010, the Greek government approved a bill aimed at reforming the country's social security system. The statutory retirement age for women was raised by five years to 65 immediately to match the current retirement age for men. These measures are aimed to increase employment and GDP and hence tax revenues and to lower social benefits. Following the reform, the additional consolidation requirement to meet any of the targets is much less demanding. Reducing debt to $50 \%$ of GDP requires a strengthening of the primary balance by $5.6 \%$ of GDP, instead of almost $12 \%$ of GDP before the reform. 
Figure 7.7. The effects of delaying retirement by five years on fiscal gaps

Change in underlying primary balance needed to bring gross financial liabilities to $50 \%$ of GDP in 2050

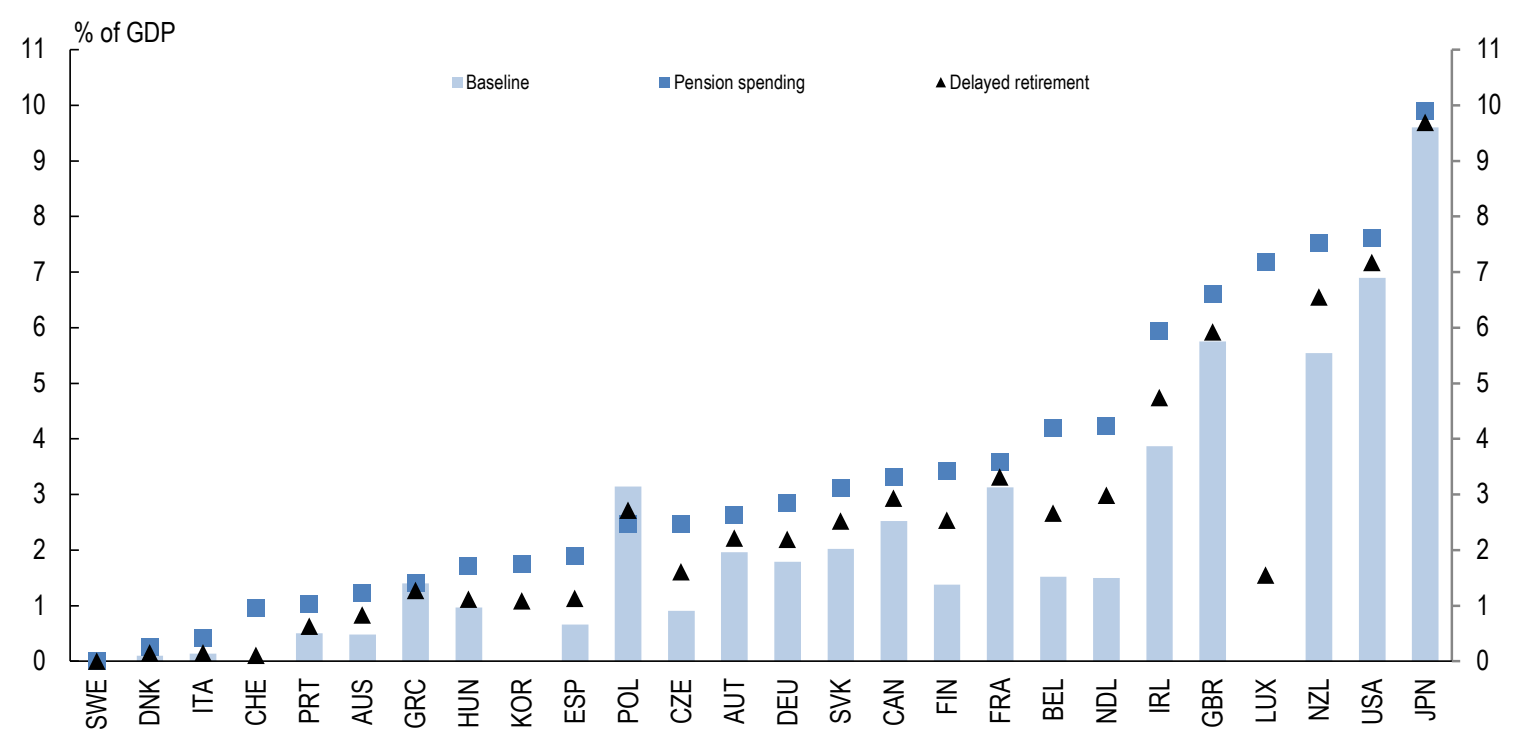

Note: The change is from the underlying primary balance projected for 2012.

Given the long-run planning inherent in retirement, pension reforms should be adopted well ahead of when changes take place. In turn, except in circumstances requiring large front-loaded measures, pension reforms contribute to fiscal consolidation in the long run. However, positive short-term growth effects could be realised to the extent that sustainability is credibly restored through planned reforms, with favourable effects on current interest rates.

Disability benefits should be better targeted

Governments provide disability insurance to compensate working-age persons against loss of incomeearning capacity. However, disability payment schemes have increasingly become a benefit of last resort in many countries due to a variety of factors, including a shortening of the period of receipt of unemployment benefits or the tightening of eligibility for early retirement. That disability payments are poorly targeted is suggested by a number of indicators, not least of which is the marked rise in the number of disabled at an age close to retirement (Hagemann, 2012). Governments now spend on average slightly more than 13/4 per cent of GDP on disability payments, ranging from virtually nil in Mexico and Turkey to around 3\% of GDP or more in the Nordic countries (Figure 7.8).

Reducing inflows to and raising outflows from disability status hold promise of delivering fiscal savings. An important step in tightening eligibility is to link benefits more closely to the degree of incapacity, including through repeated tests of work capacity and more reliance on medical criteria, and to tailor benefits to actual needs rather than providing standard allowances. For instance, mobility allowances can be provided to compensate for the extra cost incurred by disabled persons, and resident family members can be offered "caretaker" allowances instead of paying costlier out-side services. The favourable impacts on labour supply and the knock-on revenue effects would, over time, provide additional consolidation. 
Figure 7.8. Disability benefits in OECD countries

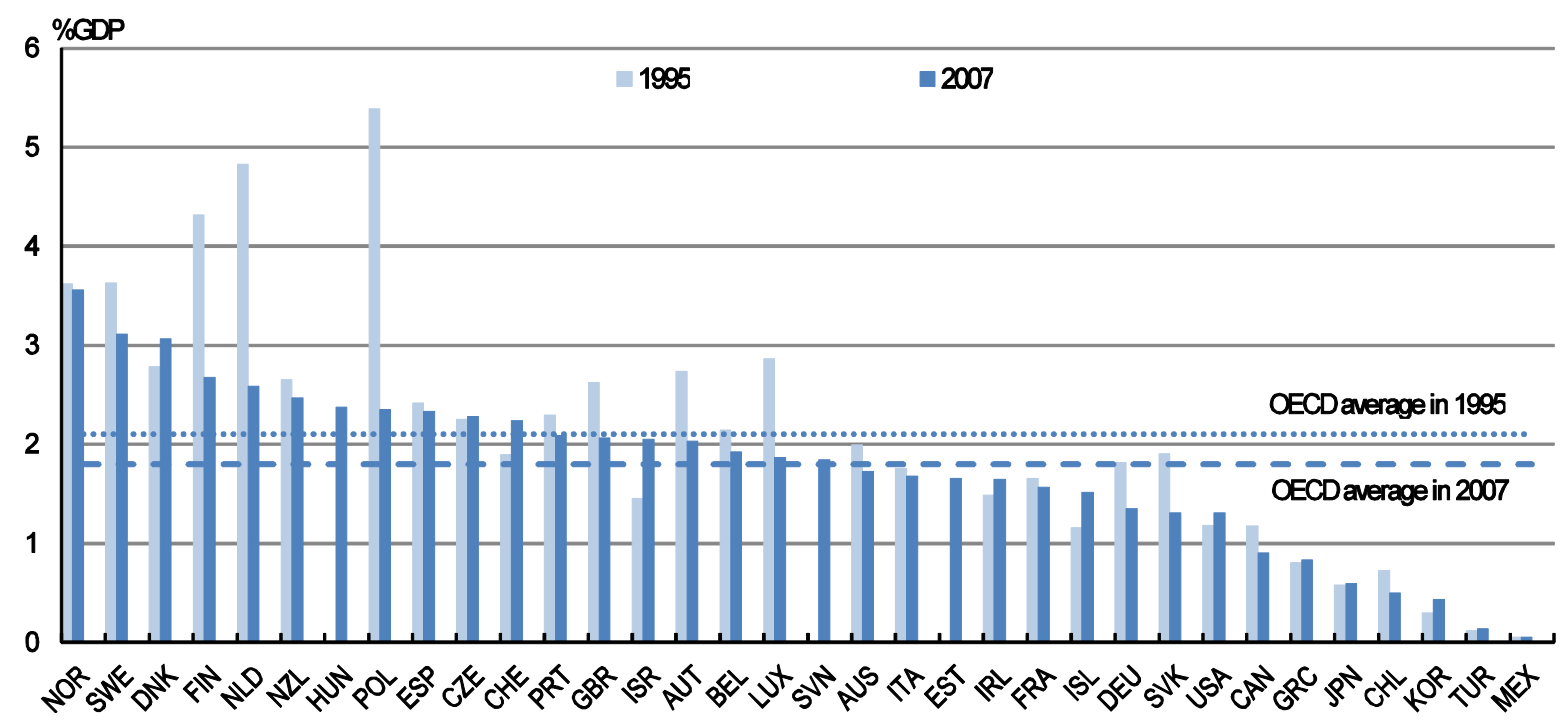

Source: OECD SOCX Database.

Reforming unemployment benefit schemes

Unemployment insurance is an indispensible lubricant for well-functioning market economies (ensuring a social cushion and efficient matches, as well as acting as an automatic stabiliser), but some features can add unnecessary cost and can be counter-productive. For example, overly generous benefits (i.e., high replacement rates and long duration of benefit payment) can undermine incentives to return to work (Bassanini and Duval, 2006; Blanchard and Wolfers, 2000). Many countries provide generous replacement rates (Figure 7.9) and differences in generosity contribute to cross-country variations in spending. ${ }^{34}$ In 2007 , unemployment benefit outlays averaged around $0.75 \%$ of GDP, ranging from virtually nil in Turkey to around 3\% of GDP in Belgium.

Many OECD countries have reformed their unemployment compensation schemes. While such reforms hold promise of some direct budgetary savings, their principal contribution to fiscal consolidation lies in the beneficial impact on the labour market. The initial net budgetary impact could be negative if, as is warranted in many countries, reduced generosity is accompanied by strengthened activation strategies (OECD, 2009). ${ }^{35}$ But long-run gains in economic performance can be substantial. Bouis and Duval (2011), for instance, demonstrate that the rate of structural unemployment could be lowered by $0.5-1.5$ percentage points.

34. For instance, prior to the recent and unusually severe recession, fewer than $20 \%$ of job seekers in the United States and Korea (which have among the lowest net replacement rates) were typically continuously unemployed for six months or longer, compared with $2 / 3$ of the unemployed in Belgium and Germany (OECD, 2009).

35. Such strategies provide that the unemployed can continue to receive benefits on condition that they remain engaged in active job search and take steps to improve their employability (e.g., through training). 
Figure 7.9. Net income replacement rates for unemployment ${ }^{1}$

\section{Percentage of earnings replaced during a 5-year unemployment spell ${ }^{2}$}

$\%$

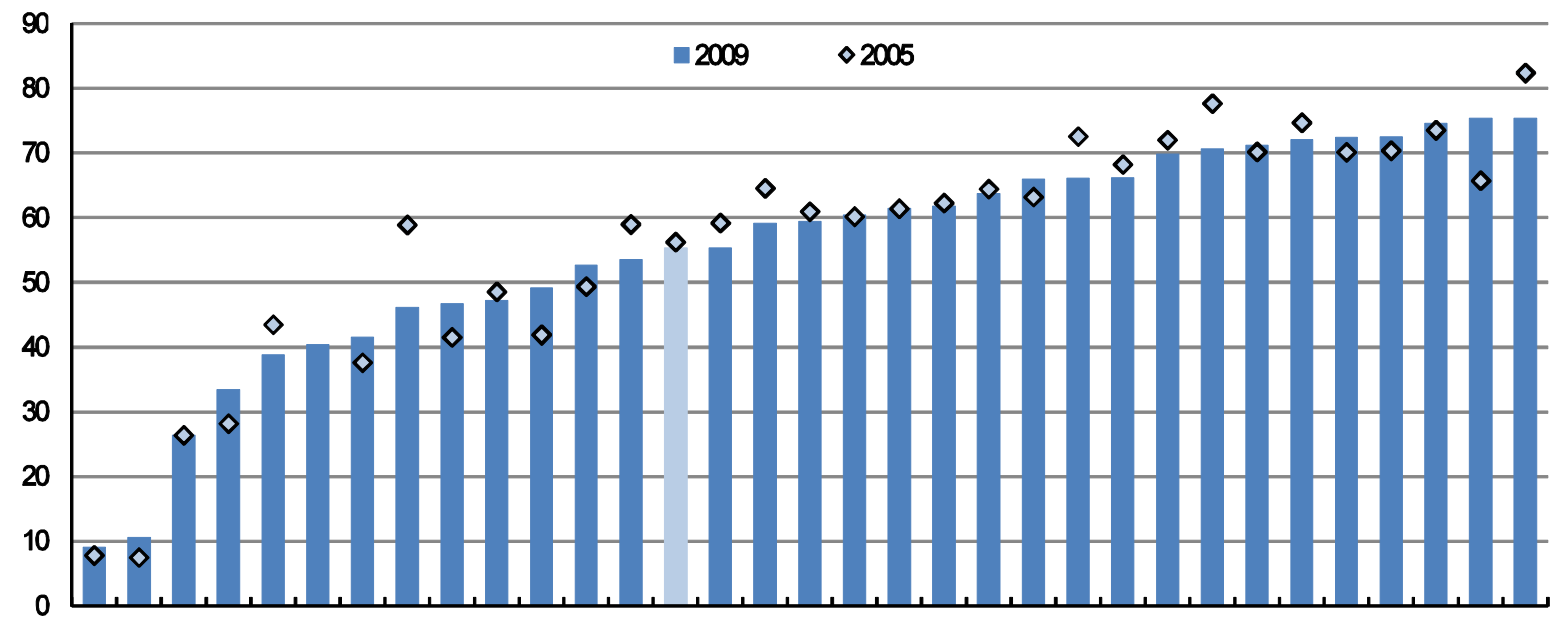

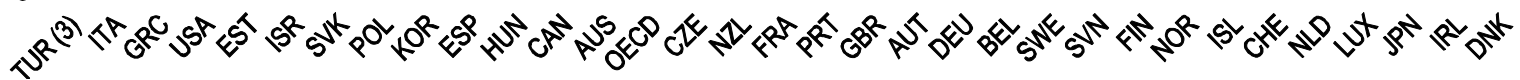

1. Overall average of net replacement rates for four family types and two earnings levels $(67 \%$ and $100 \%$ of average worker earnings).

2. After tax and including unemployment benefits, social assistance, family and housing benefits in the 60th month of benefit receipt

3. For Turkey, the average worker earnings (AW) value is not available and calculations are based on the average production worker earnings (APW)

Source: OECD (2010), Benefits and Wages: OECD Indicators.

Some countries may need to reconsider the generosity of family benefits

Many OECD countries spend large sums in support of families with dependent children. Public spending on family benefits averages just under $2 \%$ of GDP across the OECD. Considerable differences across countries are rooted in history and different attitudes towards the role of government in reconciling work and family responsibilities (OECD, 2011b). The configuration of benefits also varies across countries, but often includes paid maternity and paternity leave, child and child-care benefits and allowances (including via tax preferences) and housing support. Assessing the effectiveness of family benefits in balancing family responsibilities versus work is challenging. On the one hand, the Nordic countries, which provide generous and universal public support into a child's early adulthood, have above average birth rates, and parenthood and career are perceived as simultaneously achievable. On the other hand, in English-speaking countries, where means-testing of benefits plays a greater role, birth rates and female employment rates are also above average. In other countries, however, benefit levels and unconditional (beyond family status) provision tend to reduce labour market participation and thereby unintentionally reduce lifetime income.

In a context of hardening budget constraints, prioritisation may justify reviewing eligibility for benefits. One option is to introduce or strengthen the linkages between continued receipt of benefits and job search and employment take-up. This would also have positive indirect feedback effects through increased labour supply. For example, governments could shift spending away from child allowances toward child-care support to encourage labour force participation. A second option that would reduce outlays and impart a greater degree of fairness is to introduce means-testing, although such selectivity raises implementation costs and can have adverse incentive effects (by raising the marginal tax for those eligible for benefits). 


\section{Revenue instruments}

Harmful distortions are inevitably caused by revenue levels that reached on average $35 \%$ of GDP prior to the onset of the recession (OECD, 2011c; Table 7.2). But some taxes are more harmful to growth than others. Taxes on income (including payroll taxes) and consumption both discourage labour supply. The income tax can also discourage saving, depending on whether the income or the substitution effect dominates. In principle, social insurance contributions are not a tax insofar as they "purchase" benefits and people often perceive them as distinct from taxes. To the extent that social insurance systems are often redistributive, however, a portion of the contribution can be seen as a pure tax. ${ }^{36}$ Taxes on corporate income can depress investment, lowering capital accumulation and productivity. Moreover, a widely accepted dictum of public finance is that the excess burden of a tax increases by the square of its rate. ${ }^{37}$ Governments should thus concentrate on broadening tax bases to keep tax rates as low as possible. Indeed, even revenue-neutral base-broadening reforms hold promise of improving growth and, in turn, contributing to fiscal consolidation over the medium term.

Table 7.2. Tax structures

OECD-wide percentage share of each category in total tax revenue (unweighted average)

\begin{tabular}{lrrr}
\hline & 1990 & 2000 & 2008 \\
\cline { 2 - 4 } Personal income tax & 29.6 & 25.5 & 25.0 \\
Corporate income tax & 7.9 & 9.8 & 10.1 \\
Social security and payroll taxes & 23.1 & 25.4 & 26.4 \\
VAT/GST & 33.0 & 32.8 & 31.7 \\
Other consumption taxes & & 5.7 & 5.4 \\
$\quad$ Property taxes & 0.7 & 0.9 & 1.4 \\
$\quad$ Other taxes & 100.0 & 100.0 & 100.0 \\
Total & & & 34.6 \\
Memorandum item: & 33.1 & 35.5 & \\
$\quad$ Share of total revenue in GDP & & & \\
\hline
\end{tabular}

Source: OECD Revenue Statistics.

Some taxes, however, are natural candidates for fiscal consolidation programmes both from an efficiency and revenue-raising perspective. The efficiency costs of taxes on immobile property are lower than on consumption or income. Property taxes are a small share of overall tax revenue in many OECD countries (Table 7.2), and are thus a potential source of less harmful revenue mobilisation, although the amount raised is likely to remain limited. ${ }^{38}$ Moreover, property taxes are currently so low in some countries that they introduce a distortion favouring property over other sources of capital income. In addition, where they are low or non-existent, corrective taxes such as so-called "sin" taxes that can help deter harmful behaviours (e.g., alcohol and tobacco consumption), or taxes on polluting activities or consumption (e.g., fossil fuels) can improve welfare while boosting revenues.

Distributional aspects of revenue mobilisation are also important, however. Revenue choices need to be sensitive to both horizontal and vertical equity. The former implies that persons of equal ability to pay should bear the same tax burden and the latter that the average rate of taxation should rise with the ability

36. Alternatively, the "pure tax" component is the excess of the social insurance contribution rate over what the contributor would be willing to pay.

37. The excess burden of a tax also depends on the elasticities of supply of and demand for the taxed item.

38. In most countries, property taxes are a main source of finance for sub-national governments, posing potentially challenging fiscal federalism problems should national property taxes be introduced or raised. 
to pay. To a large extent, base-broadening reforms are an important means of infusing more horizontal fairness into tax systems. Ensuring vertical equity poses greater difficulties, since rising marginal tax rates result in disproportionately higher excess burdens.

\section{Base-broadening through reduced tax expenditures}

All OECD governments use tax expenditures to promote a range of policy objectives. The scope of tax expenditures varies greatly across OECD countries, but they account for very substantial revenue leakages in some cases. For instance, in the United States, there were 247 identified tax expenditures affecting personal and corporate taxes in 2008 , with an estimated value roughly equal to total personal income taxes collected in that year (Congressional Research Service, 2008). In its 2011 budget bill the French government reduced tax expenditure yielding revenue gains of close to $1 \%$ of GDP. Not all tax expenditures are undesirable, though, as some improve efficiency. Many, however, are distorting, poorly targeted, and contribute to a lack of transparency. Typically, the most costly tax expenditures are those aimed at boosting retirement savings, promoting homeownership, health insurance and charitable giving $(\mathrm{OECD}, 2010 e)$. In some cases, estimates of the revenues forgone by such tax expenditures can exceed a percentage point of GDP and the aggregate impact of all tax expenditures likely to exceed several percentage points of GDP in most OECD countries.

Retirement saving incentives

While many countries provide tax-favoured treatment of saving for retirement, more effective and equitable alternatives are available that could also reduce revenue losses. Although such tax preferences are found to boost retirement savings per se, there is scant evidence that they raise aggregate private saving. Instead, they result in a reallocation of saving from non-tax preferred to tax-preferred vehicles, while causing substantial revenue leakages, which may even reduce national aggregate saving. For instance, phasing out such incentives could yield 1.7\% of GDP or more in additional revenues on average across a sample of OECD countries (Antolin et al., 2004). While promoting retirement planning is a worthwhile policy objective, other means than tax preferences may be more effective, such as mandatory savings with or without opt-out provisions, as in New Zealand, the United Kingdom and the United States. Where distributional concerns are important, matching government contributions or tax credits can be provided to low-income savers, as in Australia.

\section{Housing}

Preferential tax treatment of owner-occupied housing is one of the costliest tax preferences in many OECD countries. The most important source of housing-related revenue leakages arises from the tax exemption granted to the implicit rental income of the owner-occupied home. Whereas the owner of a residence that is rented pays tax on the rental payments (less interest and operational costs), the implicit rental income of the owner-occupant is tax-exempt in the vast majority of member countries, except, notably, in the Netherlands, Sweden and Switzerland. ${ }^{39}$ Despite the exclusion of the implicit rental income, some countries nevertheless allow the deductibility of mortgage interest, as well as property taxes (normally paid at the sub-national level). In addition, many countries provide favourable treatment to long-term capital gains from the sale of owner-occupied housing, adding further to the post-tax attractiveness of investment in housing.

The balance of the pros and cons of the current treatment of owner-occupied housing argues for substantial reform in most countries. In the absence of wholesale reform that would incorporate the

39. In the Netherlands and Switzerland, however, taxable imputed rentals are very low, which combined with mortgage interest deductibility acts to reduce personal income tax revenues significantly. 
implicit rental income of owner-occupiers, eliminating or drastically reducing the deductibility of mortgage interest could yield significant revenue gains. A reformed tax treatment of housing would yield potentially substantial revenues. For instance, the US Congressional Budget Office (CBO, 2011b) estimates that the cumulative 2010-14 cost of the mortgage interest deduction could be around $0.6 \%$ of GDP. Moreover, by removing a bias favourable to owner-occupied housing, reform could improve the allocation of capital, yielding higher per capita income in the long run. However, implementing reforms in this area may need to be implemented carefully in countries where the housing market is still fragile.

Other income tax preferences

There is no shortage of tax preferences offering opportunities to broaden the income tax base. Notwithstanding the original public policy merits that underpinned the introduction of each preference, the large deficit-reducing requirements faced by many countries argue for a re-assessment of the relative merit of each $(\mathrm{OECD}, 2011 \mathrm{c})$. For instance, in some countries, the exclusion of employer provided health insurance is highly inequitable, both horizontally and vertically, and distorts consumer choices of health care services. This is a particularly costly and damaging preference in the United States, where it is estimated that the exclusion amounts to roughly $0.8 \%$ of GDP (CBO, 2011b).

\section{Capping income tax expenditures}

Reducing or eliminating individual tax expenditures poses considerable political challenges, so that across-the-board limitations may be the most viable option in many countries. Constituencies for each taxfavoured income exclusion and deductible (or creditable) expense can be strong and vocal political forces support the status quo. Lowered statutory marginal tax rates can undermine the value of, and thus support for, preferences. But this poses a chicken and egg dilemma: lowered rates require a broadened base. An alternative is to set a ceiling on the total value of itemised deductions, a proposition put forward recently by Feldstein et al. (2011).

\section{Tax expenditures and exemptions for VAT}

While the VAT is widely recognised as an efficient and buoyant revenue source, its revenue potential is not fully used. Indeed, with the exception of New Zealand, a substantial portion of potential revenue is foregone in most countries due to a combination of reduced VAT rates, a narrow base, and low compliance (Figure 7.10). There is thus considerable scope for boosting revenue through VAT reforms. Direct fiscal consolidation aside, broadening the base and reducing the number of rates offer considerable scope to improve administration and compliance, by reducing complexity and countering political pressure for additional low rates. ${ }^{40}$ Lower rates on items that make up a relatively larger share of low-income households' budgets benefit the wealthy as well, and therefore perform poorly as a means of making the VAT progressive. A more effective means may be to target compensatory increased cash transfers or refundable tax credits to compensate low-income households.

Financial services are typically exempted from the VAT, resulting in potentially sizeable revenue losses. The exemption has largely been due to technical difficulties in determining the precise tax base for margin-based services (i.e., intermediation). Since much of VAT paid by financial service providers on inputs is non-recoverable, the sector's VAT exemption causes a number of economic distortions that result in more household consumption of financial services, and less use of and greater self-provision of financial

40. One justification for multiple tax rates has been the "inverse elasticity rule" (Ramsey, 1927), which suggests that minimising the excess burden of taxation is theoretically achieved by tax rates that vary inversely with the price elasticity of the base. However, this result collapses if there is a non-linear income tax, in which case there should be a uniform tax rate (Atkinson and Stiglitz, 1976). 
services by businesses. However, the evolution of accounting methods and information systems has reduced the technical obstacles to imposing VAT on financial services considerably (OECD, 2010f). Moreover, following the recent financial crisis, there is increased interest among governments in both raising revenue from financial institutions and reducing moral hazard in the financial services via a new tax on financial services. To this effect, several proposals have been put forward by the IMF $(2010 b)$ that offer a potential alternative to a VAT on financial services (OECD, 2011e).

Figure 7.10. Value added tax performance: the VAT revenue ratio

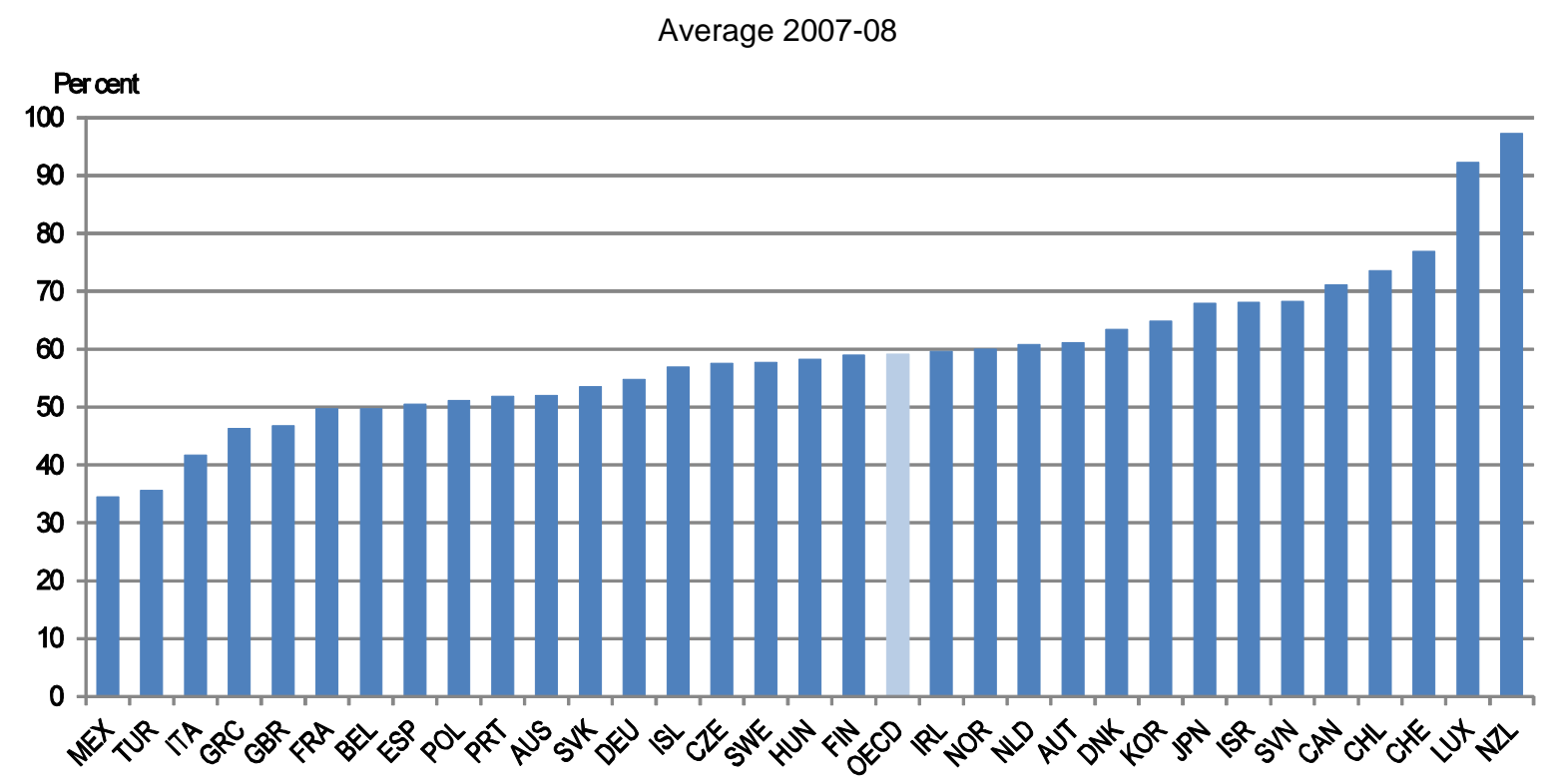

Note: The VAT revenue ratio measures the difference between the VAT revenue actually collected and what would theoretically be raised if VAT was applied at the standard rate to the entire potential tax base in a "pure" VAT regime and all revenue was collected: The VAT revenue ratio equals VAT Revenue/(Consumption * Standard VAT rate)*100.

Source: OECD (2011), Consumption Tax Trends 2010: VAT/GST and Excise Rates, Trends and Administration Issues.

The IMF has proposed two alternatives. The first, a "Financial Stability Contribution" would be a flat levy imposed on all financial institutions, the rate varying by type of institution and, eventually, by the assessed degree of riskiness of an institution. The alternative proposal is a "Financial Activities Tax" (FAT) levied on the sum of profits and remuneration of financial institutions. The revenue yield would vary across countries, depending on factors affecting the size of the tax base (i.e., the relative size, profitability and wage structure of financial sectors). A number of alternative forms of the FAT could be contemplated. As an illustration, under the form with the broadest base, a FAT at 5\% could yield about $0.14 \%$ of GDP in Norway, and $0.31 \%$ of GDP in the United Kingdom (IMF, 2010 $b$, Appendix 6). The ability of countries to successfully implement unilaterally such financial sector taxes is constrained by the risk of tax and regulatory arbitrage, pointing to the need for international coordination and cooperation. However, a number of countries have already proposed or unilaterally put in place a tax on financial systems. ${ }^{41}$ For example, Sweden is phasing in a tax on uninsured liabilities that will accumulate in a fund that would amount to around $2.5 \%$ of GDP.

41. They include France, Germany, Italy, Sweden the United Kingdom and the United States. The European Commission has also advocated such taxes. 


\section{Increasing environmental taxation}

Environmental taxes hold the promise of both boosting revenue and helping to achieve environmental objectives by discouraging pollution. While some countries raise considerable revenues from such taxes, reaching 4\% of GDP in Denmark and the Netherlands in 2008, their yield is relatively low in several countries, notably Canada, New Zealand and the United States (Figure 7.11). Nonetheless, imposing a tax on carbon emissions or auctioning tradable emission rights to contain greenhouse gas emissions has become more widespread. For example, the European Union has auctioned permits as part of the Emission Trading Scheme. Despite such developments, many countries maintain differences in taxation depending on fuel type that run counter to estimates of environmental externalities. From a fiscal consolidation perspective, greenhouse gas levies could generate around 2\% of GDP (de Serres et al., 2010).

Figure 7.11. Environmental tax revenues in OECD countries

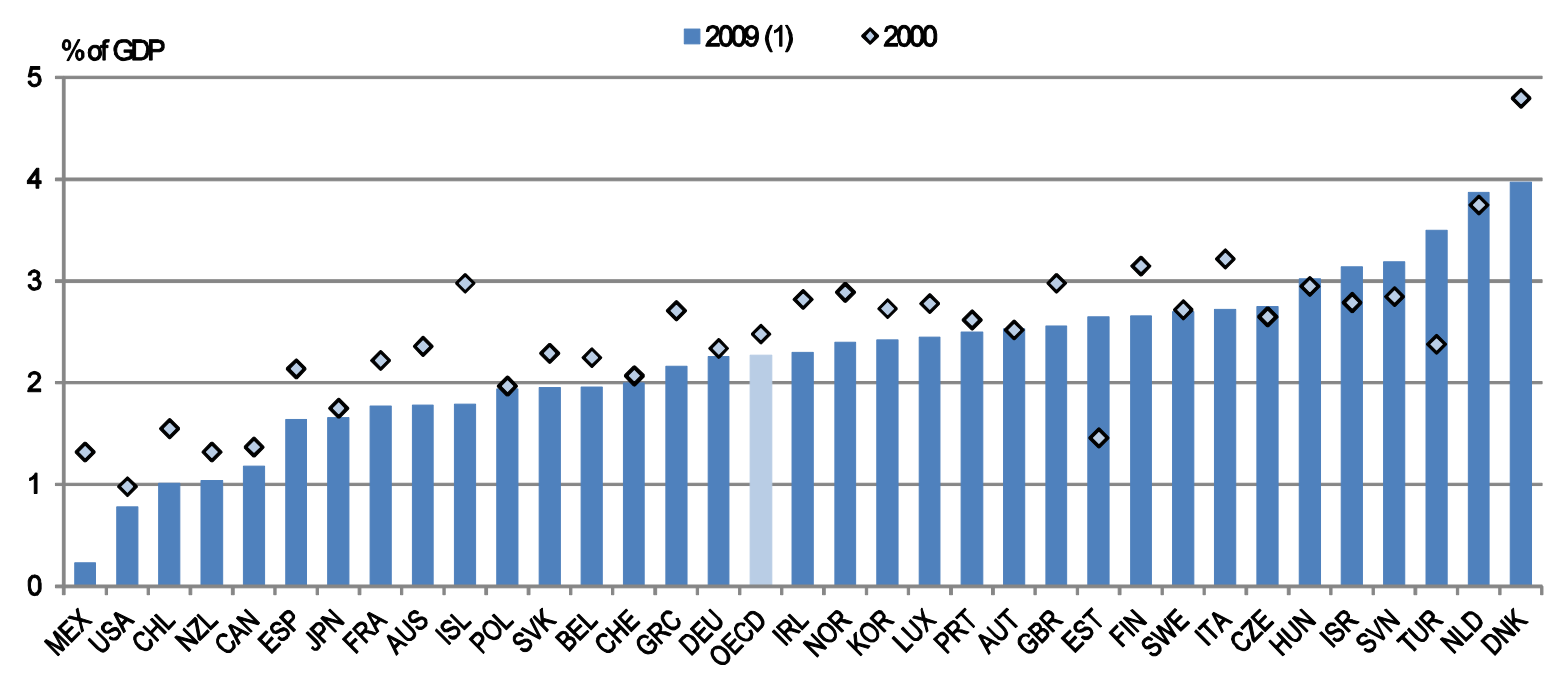

1. 2008 for Belgium, Greece and Poland.

Source: OECD/EEA Database on instruments used for environmental policy and natural resources management.

\section{Reducing tax avoidance}

Potentially significant revenue gains are possible in many countries through reductions in the scope of tax avoidance schemes that provide favourable tax treatment to selected forms of capital income. For instance, capital gains are often taxed at a lower rate than other capital income, or not at all in some countries. Favourable treatment can also be provided through lighter taxation of stock options or carried interest. ${ }^{42}$ Absent a market failure to justify preferred treatment that tends in any case to favour generally highly paid executives, finance professional and entrepreneurs, closing such loopholes would further enable overall income marginal tax rates to remain lower than otherwise.

\section{A policy matrix for growth-promoting fiscal consolidation}

The post-crisis fiscal consolidation challenge is an opportunity for OECD governments to develop coherent strategies to tackle fiscal policy issues that both undermine sustainability and weaken economic growth. The previous discussion of the various instruments, which evidently constitute but a limited part of a potential policy agenda, sheds light on the ways in which reforms can both contribute to fiscal

42. Carried interest is a share of profits of a partnership that is paid to the manager as a form of compensation. 
consolidation, improved economic performance, higher levels of welfare and fairer public finances. Table 7.3 attempts to bring together the key issues surrounding each policy area, including important tradeoffs with which governments need to grapple in designing a sustainable strategy. While comparable information on the potential contributions of spending and revenue measures to fiscal consolidation are typically not available, and particularly not in a static or dynamic scoring framework, Table 7.4 brings together estimates that could inform a choice of where potential to make savings or increase revenues may exist. Even without being able to quantify all the possible measures across countries, the cumulative potential cuts in spending and increases in taxation are sizeable. On average across countries, savings could reach around 6\% of GDP, with somewhat more available on the spending side. Given that there are measures that are difficult to quantify this is a lower estimate. Furthermore, the potential tends to be somewhat greater in the English-speaking countries which generally face the larger consolidation needs. A large share of the savings in spending would come from reaping efficiency gains, which are likely to take some time to emerge. On the revenue side, relatively large opportunities exist for the greater use of environmental taxes and the broadening of income and indirect tax bases.

The implementation of fiscal consolidation will need to take into account social trade-offs. In some cases, potential trade-offs can be mitigated by re-designing tax and benefit systems, whereas in others involve deeper choices in system design (Joumard and Pisu, 2012). With respect to taxation opportunities exist to eliminate some tax expenditures, many of which concern income taxes, which do nothing for or harm distributional goals while introducing distortions. In other cases, such as lower VAT rates and exemptions, eliminating the distortions would reduce the intended progressivity of some of the exemptions or reduced rates. In these cases, adjustments to transfers may be required. Transfers tend to be progressive, but they can impact on labour force participation and thus design is important. For instance, high unemployment benefits, which fall over time, may have only limited adverse effects on work incentives. Besides design features, the scope of social transfers affects the trade off with the social dimension. Universal benefits are likely to require a comparatively high tax take to finance them, whereas meanstested transfers limit the total cost, but are likely to introduce adverse incentive effects. Ultimately, politicians will need to decide the balance between universality and means testing, which in turn requires balancing support for low income families with the consequences of higher marginal effective tax rates for many more families.

Fiscal consolidation also poses difficult political economy challenges (OECD, 2010b). The structural reforms that underpin consolidation have unavoidably differential impacts on various segments of the population, reflecting in part different endowments and preferences, not to mention acquired economic rents. The extent to which partial compensation for losers should be considered will depend on a number of factors, including the ease with which the affected parties can absorb any policy-induced losses, and whether their self-interested objections risk de-railing the overall consolidation strategy. 
ECO/WKP(2012)9

Table 7.3. Trade-offs and complementarities between fiscal consolidation instruments and growth

\begin{tabular}{|c|c|c|c|c|c|c|}
\hline \multirow{2}{*}{ Policy Area } & \multirow{2}{*}{ Description } & \multicolumn{2}{|c|}{$\begin{array}{c}\text { Impact on budget } \\
\text { deficit }\end{array}$} & \multirow{2}{*}{ Impacted growth driver } & \multirow{2}{*}{ Impact on per capita GDP } & \multirow{2}{*}{ Remarks } \\
\hline & & $\begin{array}{l}\text { Short } \\
\text { run }\end{array}$ & Structural & & & \\
\hline \multicolumn{7}{|l|}{ A. Expenditure policy } \\
\hline \multicolumn{7}{|l|}{ 1. Social transfers } \\
\hline $\begin{array}{l}\text { A. Reduce generosity of } \\
\text { unemployment } \\
\text { benefits }\end{array}$ & $\begin{array}{l}\text { Net replacement rate is reduced } \\
\text { to the level in the median OECD } \\
\text { country. }\end{array}$ & - & -- & $\begin{array}{l}\text { Structural unemployment } \\
\text { rate could fall by } 0.5-1.5 \% \\
\text { depending on the pace of } \\
\text { reform and the } \\
\text { combination of measures } \\
\text { (Bouis and Duval, 2011). }\end{array}$ & $\begin{array}{l}\text { In the case of a reform that } \\
\text { reduces the generosity of } \\
\text { unemployment benefits by } \\
\text { one standards deviation, } \\
\text { GDP per capita increases } \\
\text { by } 5.2 \% \text { in } 10 \text { years, and } \\
8.5 \% \text { in steady states } \\
\text { (Barnes et al. (2011). }\end{array}$ & $\begin{array}{l}\text { Reducing the generosity of unemployment compensation, } \\
\text { notably the duration of benefits, combined with increasing } \\
\text { the amounts and improving the effectiveness of activation } \\
\text { policies, provides greater incentives to increase job } \\
\text { search. }\end{array}$ \\
\hline B. Increase ALMP & $\begin{array}{l}\text { Increase ALMP spending to } \\
\text { average (per cent of GDP) of } \\
\text { benchmark countries. }\end{array}$ & + & & $\begin{array}{l}\text { Labour utilisation is } \\
\text { improved via higher } \\
\text { employment due to more } \\
\text { effective job search. Labour } \\
\text { productivity raised via } \\
\text { improved skills job } \\
\text { matching and training } \\
\text { programs. }\end{array}$ & ++ & \\
\hline C. Family benefits & $\begin{array}{l}\text { Tighten eligibility through better } \\
\text { targeting, and link some benefits } \\
\text { to job search effort. }\end{array}$ & - & - & $\begin{array}{l}\text { Improves labour supply by } \\
\text { tying some benefits to } \\
\text { work search. }\end{array}$ & + & \\
\hline \multicolumn{7}{|l|}{ 2. Pensions } \\
\hline A. Raise retirement age & $\begin{array}{l}\text { Phase in an increase in the } \\
\text { statutory age for full pension. }\end{array}$ & - & -- & $\begin{array}{l}\text { Raises labour supply, but } \\
\text { may reduce saving, } \\
\text { depending on relative } \\
\text { strength of income and } \\
\text { substitution effects. }\end{array}$ & ++ & $\begin{array}{l}\text { Raising the effective age of retirement is more effective if } \\
\text { changes to the statutory age, and higher } \\
\text { penalties/premiums for early/delayed retirement, are } \\
\text { accompanied by other policy changes that affect } \\
\text { retirement decisions, including tax policies, availability of } \\
\text { other age-dependent benefits such as disability payments, } \\
\text { and the employability of elderly workers through ALMPs. }\end{array}$ \\
\hline $\begin{array}{l}\text { B. Index statutory } \\
\text { retirement age to } \\
\text { changes in life } \\
\text { expectancy }\end{array}$ & & Nil & -- & Labour force expands & ++ & Automatic adjustment to future fluctuations in demography \\
\hline
\end{tabular}


ECO/WKP(2012)9

Table 7.3. Trade-offs and complementarities between fiscal consolidation instruments and growth, continued

\begin{tabular}{|c|c|c|c|c|c|c|}
\hline \multirow[b]{2}{*}{ Policy Area } & \multirow[b]{2}{*}{ Description } & \multicolumn{2}{|c|}{ Impact on budget deficit } & \multirow[b]{2}{*}{ Impacted growth driver } & \multirow[b]{2}{*}{ Impact on per capita GDP } & \multirow[b]{2}{*}{ Remarks } \\
\hline & & $\begin{array}{c}\text { Short } \\
\text { run }\end{array}$ & Structural & & & \\
\hline \multicolumn{7}{|l|}{ A. Expenditure policy } \\
\hline \multicolumn{7}{|l|}{ 2. Pensions } \\
\hline $\begin{array}{l}\text { C. Reduce early } \\
\text { retirement//ncrease } \\
\text { delayed retirement }\end{array}$ & $\begin{array}{l}\text { Reduce incentives for early } \\
\text { retirement, and raise incentives for } \\
\text { later retirement, by lowering the } \\
\text { implicit tax on continued work. This } \\
\text { can included increasing the penalty } \\
\text { for early retirement, tightening } \\
\text { eligibility for other benefits such as } \\
\text { disability payments. (Duval, 2003; } \\
\text { OECD, 2011d). }\end{array}$ & - & -- & Labour force expands & + & \\
\hline \multicolumn{7}{|l|}{ 3. Health care } \\
\hline Reap efficiency gains & $\begin{array}{l}\text { Adopt OECD "best practice" for a } \\
\text { range of insurance and service } \\
\text { delivery approaches } \\
\text { (Joumard et al., 2008, 2010; OECD, } \\
\text { 2010d; IMF, 2010). }\end{array}$ & & $\begin{array}{l}-2 \% \text { of GDP } \\
\text { on average in } \\
\text { OECD during } \\
2011-17\end{array}$ & & + & $\begin{array}{l}\text { Range of possible reform measures, including } \\
\text { budget caps, supply constraints, price controls, } \\
\text { and increased use of market mechanisms. }\end{array}$ \\
\hline \multicolumn{7}{|l|}{ 4. Education } \\
\hline $\begin{array}{l}\text { Adopt "best practice" in } \\
\text { primary and secondary } \\
\text { school system }\end{array}$ & $\begin{array}{l}\text { i) Make budget process more } \\
\text { responsive to educational needs via } \\
\text { decentralization of responsibilities; } \\
\text { ii) budget management should be } \\
\text { more autonomous and focused on } \\
\text { outcomes; iii) allow greater scope } \\
\text { for competition (Gonand et al., } \\
\text { 2007; Sutherland et al., 2007). }\end{array}$ & - & $1 \%$ of GDP & & + & \\
\hline $\begin{array}{l}\text { Introduce or raise tuition } \\
\text { fees for tertiary education }\end{array}$ & $\begin{array}{l}\text { i) Tuition fees could be gradually } \\
\text { raised to levels that would close the } \\
\text { gap between private and public } \\
\text { rates of return on tertiary education. }\end{array}$ & - & -- & $\begin{array}{l}\text { Improves labour force } \\
\text { productivity via higher skills. } \\
\text { Tuition fees spur competition } \\
\text { that induces greater } \\
\text { responsiveness of } \\
\text { educational institutions to } \\
\text { demands of students. Tuition } \\
\text { fees may also shorten time } \\
\text { to complete studies. }\end{array}$ & + & \\
\hline \multicolumn{7}{|l|}{ 5. Government wage bill } \\
\hline $\begin{array}{l}\text { Restore public-private } \\
\text { sector pay relativities }\end{array}$ & $\begin{array}{l}\text { i) Some governments may wish to } \\
\text { undertake functional reviews to } \\
\text { determine warranted size and } \\
\text { structure of civil service. }\end{array}$ & & & & & \\
\hline
\end{tabular}


ECO/WKP(2012)9

Table 7.3. Trade-offs and complementarities between fiscal consolidation instruments and growth (continued)

\begin{tabular}{|c|c|c|c|c|c|c|}
\hline \multirow[b]{2}{*}{ Policy Area } & \multirow[b]{2}{*}{ Description } & \multicolumn{2}{|c|}{ Impact on budget deficit } & \multirow{2}{*}{$\begin{array}{l}\text { Impacted growth } \\
\text { driver }\end{array}$} & \multirow[b]{2}{*}{ Impact on per capita GDP } & \multirow[b]{2}{*}{ Remarks } \\
\hline & & $\begin{array}{c}\text { Short } \\
\text { run }\end{array}$ & Structural & & & \\
\hline \multicolumn{7}{|l|}{ B. Revenue policy } \\
\hline $\begin{array}{l}\text { 1. Broaden income tax } \\
\text { base }\end{array}$ & $\begin{array}{l}\text { i) Review major exclusions of } \\
\text { income from the tax base, both } \\
\text { pecuniary and in-kind. Aim for } \\
\text { improved horizontal and vertical } \\
\text { equity. ii) Assess (against } \\
\text { original aim) and reconsider tax } \\
\text { deductions and credits. See } \\
\text { OECD }(2010 e) \text {. }\end{array}$ & -- & -- & $\begin{array}{l}\text { Impact varies } \\
\text { depending on affected } \\
\text { tax preference. } \\
\text { Reduced distortions } \\
\text { improve allocation of } \\
\text { labour and capital } \\
\text { resources. Elimination } \\
\text { of preferences } \\
\text { reduces complexity of } \\
\text { compliance through } \\
\text { simplification and } \\
\text { perceptions of } \\
\text { improved horizontal } \\
\text { and vertical equity. }\end{array}$ & ++ & $\begin{array}{l}\text { Broadening the tax base allows statutory tax rates to remain } \\
\text { low or be reduced, with positive efficiency impacts and knock- } \\
\text { on effects on growth. }\end{array}$ \\
\hline 2. Broaden VAT base & $\begin{array}{l}\text { Review scope for eliminating } \\
\text { exclusions from standard VAT } \\
\text { rate with an aim to broaden the } \\
\text { base and applicability of single } \\
\text { rate. }\end{array}$ & -- & -- & & & A broader tax base allows the standard rate to be kept low. \\
\hline $\begin{array}{l}\text { 3. Introduce or increase } \\
\text { taxes on immobile } \\
\text { property }\end{array}$ & $\begin{array}{l}\text { In countries without a national } \\
\text { property tax, the central } \\
\text { government could introduce a } \\
\text { low rate residential property tax } \\
\text { or apply a surtax on subnational } \\
\text { property taxes. }\end{array}$ & -- & -- & & & \\
\hline $\begin{array}{l}\text { 4. Introduce or increase } \\
\text { greenhouse gas } \\
\text { levies. }\end{array}$ & $\begin{array}{l}\text { Introduce a carbon tax or } \\
\text { auction transferrable emissions } \\
\text { rights. }\end{array}$ & -- & -- & & & Negative impact on growth but improves welfare. \\
\hline
\end{tabular}

Note: A negative (positive) sign indicates that it would reduce (increase) the budget deficit. 
Table 7.4. Quantifying the contribution of various policy instruments to fiscal consolidation

Per cent of GDP

\begin{tabular}{|c|c|c|c|c|c|c|c|c|c|c|c|c|c|c|c|}
\hline & AUS & AUT & BEL & CAN & CHE & CZE & DEU & DNK & ESP & FRA & FIN & GBR & GRC & HUN & ISL \\
\hline \multicolumn{16}{|l|}{ EXPENDITURE } \\
\hline \multicolumn{16}{|l|}{ 1. Social transfers } \\
\hline A. Family benefits & 0.5 & 0.7 & 0.6 & - & - & 0.1 & - & 1.4 & - & 1.1 & 0.9 & 1.3 & - & 1.4 & 1.0 \\
\hline B. Disability benefits & - & 0.3 & 0.2 & - & 0.5 & 0.5 & - & 1.3 & 0.6 & - & 0.9 & 0.3 & - & 0.6 & - \\
\hline \multicolumn{16}{|l|}{ 2. Pensions } \\
\hline A. Eliminate tax breaks & 2.7 & 0.1 & 0.1 & 2.0 & & 0.1 & 0.8 & & 0.2 & 0.0 & 0.1 & 1.2 & & & 1.0 \\
\hline \multicolumn{16}{|l|}{ 3. Health care } \\
\hline A. Increase efficiency & 0.5 & 1.8 & 2.1 & 2.5 & 0.5 & 1.3 & 1.3 & 2.8 & 1.6 & 1.3 & 2.5 & 3.7 & 3.9 & 1.7 & 1.9 \\
\hline \multicolumn{16}{|l|}{ 4. Education } \\
\hline A. Increase efficiency in primary and secondary education & 0.4 & 0.4 & 0.5 & 0.2 & 0.2 & 0.2 & 0.4 & 0.6 & 0.2 & & 0.2 & 0.2 & & 0.3 & 1.1 \\
\hline B. Introduce or raise tuition fees for tertiary education & - & 0.4 & 0.4 & - & 0.4 & 0.3 & 0.4 & 0.4 & 0.2 & 0.3 & 0.4 & - & 0.4 & 0.4 & 0.3 \\
\hline \multicolumn{16}{|l|}{ 5. Government wage bill } \\
\hline A. Restore public-private sector pay relativities & - & 0.3 & 0.6 & - & - & 0.4 & 0.2 & 2.0 & 1.0 & - & 0.5 & 1.8 & - & - & - \\
\hline B. Reduce subsidies as share of GDP to OECD average & - & 2.3 & 0.8 & - & 2.4 & 0.7 & - & 1.2 & - & 0.2 & - & - & - & - & 0.4 \\
\hline \multicolumn{16}{|l|}{ REVENUE } \\
\hline 1. Broaden VAT base & 0.6 & - & 1.4 & - & - & - & 0.4 & - & 1.4 & 1.4 & 0.1 & 1.8 & 2.0 & 0.1 & 0.8 \\
\hline 2. Introduce or increase taxes on immovable property & - & 0.8 & 0.6 & - & 0.9 & 0.8 & 0.6 & & 0.3 & - & 0.5 & - & 0.8 & 0.7 & - \\
\hline \multicolumn{16}{|l|}{ 3. Environmental taxes } \\
\hline $\begin{array}{l}\text { A. Cut GHG emissions to } 20 \% \text { below } 1990 \text { levels via an } \\
\text { emission trading system with full permit auctioning }\end{array}$ & 4.2 & 1.8 & 1.8 & 2.5 & 1.8 & 1.8 & 1.8 & 1.8 & 1.8 & 1.8 & 1.8 & 1.8 & 1.8 & 1.8 & \\
\hline
\end{tabular}


Table 7.4. Quantifying the contribution of various policy instruments to fiscal consolidation, continued

\begin{tabular}{|c|c|c|c|c|c|c|c|c|c|c|c|c|c|c|c|}
\hline & IRL & ITA & JPN & KOR & LUX & MEX & NLD & NZL & NOR & POL & PRT & SVK & SWE & TUR & USA \\
\hline \multicolumn{16}{|l|}{ EXPENDITURE } \\
\hline \multicolumn{16}{|l|}{ 1. Social transfers } \\
\hline A. Family benefits & 0.7 & - & - & - & 1.2 & - & 0.1 & 1.1 & 0.9 & - & - & - & 1.4 & - & - \\
\hline B. Disability benefits & - & - & - & - & 0.1 & - & 0.8 & 0.7 & 1.8 & 0.6 & 0.3 & - & 1.3 & - & - \\
\hline \multicolumn{16}{|l|}{ 2. Pensions } \\
\hline A. Eliminate tax breaks & 1.2 & 0.0 & 0.7 & & 0.5 & 0.2 & & & 0.6 & 0.2 & 0.1 & 0.2 & & & 0.8 \\
\hline \multicolumn{16}{|l|}{ 3. Health care } \\
\hline A. Increase efficiency & 4.8 & 1.1 & 0.8 & 0.6 & 2.0 & 0.7 & 2.7 & 2.6 & 1.5 & 1.5 & 1.0 & 2.7 & 2.7 & 1.5 & 2.7 \\
\hline \multicolumn{16}{|l|}{ 4. Education } \\
\hline A. Increase efficiency in primary and secondary education & 0.3 & 0.4 & 0.2 & - & 0.5 & - & 0.3 & 0.3 & 0.8 & 0.2 & 0.1 & 0.2 & 0.5 & - & 0.8 \\
\hline B. Introduce or raise tuition fees for tertiary education & 0.3 & 0.2 & - & - & 0.4 & 0.1 & 0.2 & - & 0.4 & 0.1 & 0.1 & - & 0.4 & 0.4 & - \\
\hline \multicolumn{16}{|l|}{ 5. Government wage bill } \\
\hline A. Restore public-private sector pay relativities & 0.9 & 1.1 & 0.6 & - & 0.8 & - & 0.3 & 0.9 & - & 2.2 & - & 0.8 & 0.7 & - & 0.5 \\
\hline B. Reduce subsidies as share of GDP to OECD average & - & - & - & - & 0.2 & - & 0.1 & - & 0.7 & - & - & 0.2 & 0.1 & - & - \\
\hline \multicolumn{16}{|l|}{ REVENUE } \\
\hline 1. Broaden VAT base & 0.4 & 2.6 & - & - & - & $2 . .5$ & - & - & 0.2 & 1.4 & 1.2 & 0.6 & - & 3.3 & \\
\hline 2. Introduce or increase taxes on immovable property & 0.2 & 0.4 & - & 0.0 & 0.9 & 0.8 & 0.4 & - & 0.7 & - & 0.3 & 0.6 & 0.2 & 0.9 & - \\
\hline \multicolumn{16}{|l|}{ 3. Environmental } \\
\hline $\begin{array}{l}\text { A. Cut GHG emissions to } 20 \% \text { below } 1990 \text { levels via an ETS } \\
\text { with full permit auctioning }\end{array}$ & 1.8 & 1.8 & 1.2 & & 1.8 & & 1.8 & 4.2 & & 1.8 & 1.8 & 1.8 & 1.8 & & 2.2 \\
\hline
\end{tabular}

Notes:

An empty cell indicates that no information was available. Cells with a dash indicate that no savings are available from this source.

Estimates for family benefits are based on reducing the figure reported in the OECD Socex Database to the unweighted OECD average as a per cent of GDP.

Estimates for disability benefits are based on reducing the figure reported in the OECD Socex Database to the unweighted OECD average as a per cent of GDP.

The elimination of tax breaks for retirement is based on data for 2007 from OECD (2011), Pensions at a Glance.

Health care efficiency estimates are from Joumard et al. (2010).

Education efficiency estimates are based on Sutherland et al. (2007) updated to 2007 spending figures.

Tuition fees for tertiary education are based on raising direct household expenditure for tertiary education institutions to the unweighted average of those countries where households

spend on this categry.

Government wage relativities are based on returning the government to private sector wage ratio in the early 2000s.

Estimates for subsidies are based on reducing national account data for 2009 to the unweighted OECD average.

The figures for broadening VAT base assume collection efficiency rises to the unweighted OECD average.

The figures for immovable property are based on the unweighted average for 2008 from the Revenue Statistics.

Revenues from greenhouse gas emissions are based on de Serres et al. (2010). 


\section{Institutional frameworks supporting fiscal consolidation}

Better institutional frameworks can lend credibility to consolidation efforts and underpin the commitment to sustainability. And indeed there have been significant reforms in this area. These include the introduction of fiscal rules and modifications of budget frameworks (such as limits on debt set in constitutions, as in Spain, and the reintroduction of PayGo rules in the United States), the establishment of independent fiscal councils or legislative changes to establish more credible institutional frameworks. Fiscal rules and different types of fiscal institutions can lend credibility, but they are not a sufficient condition. When a government shows no strong commitment, such rules and institutions are fragile.

\section{Rationales for fiscal rules and budgeting procedures}

Institutional mechanisms such as fiscal rules and budgeting procedures can act against incentives to engage in inappropriate budgetary behaviour and thus underpin consolidation efforts. For example, the government may be subject to a deficit bias, the budget process being myopic, not taking into account longer-term issues or decision-making can lead to allocative inefficiencies. There are a number of reasons for such issues to emerge, which include (Calmfors and Wren-Lewis, 2011):

- Informational problems - over-optimism such that budget outcomes are always poorer than anticipated; better information would raise the accountability of governments.

- Impatience or time-inconsistent preferences - for example, a government may take less account of long-term issues knowing that it may lose office.

- Common-pool problems - when many decision makers can influence budgets, but the costs are spread widely, the decision makers may fail to internalise the overall costs of higher spending and debt.

- Time inconsistency and inflation bias - if fiscal policy is used as a stabilisation tool, raising output and inflation in the short run, this could lead to a deficit bias, if not corrected during the upswing.

Given the wide range of pathologies that give rise to fiscal problems, the appropriate remedy should be related to the cause and the nature of the economy. For example, whether the deficit bias arises due to a common-pool problem or over-optimism and myopia, different types of institutions and rules will provide a remedy. In some cases, these considerations would call for greater budgetary transparency, though when that is not sufficient more formal fiscal rules and fiscal councils may be needed to ensure that fiscal policy remains on track to meet fiscal consolidation targets.

\section{Budgetary procedures}

Budgetary procedures can support fiscal consolidation and help fiscal policy stay on track while bringing debt down to prudent levels. For example, Larch and Turrini (2008) found evidence that the likelihood of a fiscal consolidation starting and succeeding in controlling debt was higher in countries with stronger budgetary procedures. Empirical evidence suggests that the way in which a budget is formulated and implemented can instil greater discipline, while transparency in budget procedures can help hold government accountable to meeting their objectives. Governments that reformed their budget procedures (including introducing fiscal rules, see below) often in response to crises in the 1990s - such as Australia, Canada, Finland and Sweden - have generally experienced smaller difficulties during the recent crisis. 
Budget formulation can be affected by the concentration of power, which allows the executive to implement a stricter budget (less subject to pressure from spending ministries and the legislative to alter budgets) and a stricter implementation of the budget law (von Hagen, 1992). Top down budgeting, which sets lump sum allocations that reflect aggregate priorities, coupled with greater ministerial autonomy and accountability are generally conducive to better budgetary outcomes. Strict enforcement of the budget can be underpinned by supporting institutions. For example, requiring ministers to demand a supplementary budget when they approach their spending ceiling or holding them personally responsible for budget implementation can provide strong incentives for fiscal discipline.

Multi-annual budgeting may be conducive to implementing sustained consolidation programmes, and may facilitate reforms that take longer to implement than possible in an annual budget approach. To be effective, however, the medium-term objective should be anchored on a longer-term target, such as a debt target. When combined with a focus on output and performance, a medium-term framework can give a better indication of whether fiscal policy is on track to meet consolidation goals. However, a number of governments do not report whether fiscal outturns are consistent with targets. ${ }^{43}$ And not all countries that have implemented multi-year budgeting have enjoyed marked improvements in budgetary outcomes, suggesting that other conditions are necessary. ${ }^{44}$

There are considerable differences in transparency across OECD countries. ${ }^{45}$ Improving transparency could help hold governments accountable in several ways. For example, transparency in the choice of macroeconomic assumptions so that they can be compared with those used by independent forecasters may limit the possibility of manipulating them to generate rosy budget projections. An alternative way to improve the credibility of budgetary projections is to use key budgetary assumptions made by independent bodies. For example, in Chile a group of independent experts provide the estimates of potential output and the long-term copper price. In other cases, transparency can be augmented by other budgetary institutions. For example, there is some evidence that more robust institutional frameworks limit the possibility of under-reporting deficits. Blume and Voigt (2011) present evidence that countries with audit institutions possessing stronger mandates tend to have better budgetary outcomes. ${ }^{46}$ De Castro, Pérez and Vives (2011) find that the European Commission's index of fiscal rule strength is positively correlated with smaller negative revisions to budget balances.

Considerable differences exist across countries with respect to reporting off-budget spending. In some cases, it is required that such spending be reported with the budget and or needs legislative approval, while in other cases, contingent liabilities are not defined by law and it is therefore difficult to enforce accurate reporting. ${ }^{47}$ An additional attraction of greater transparency and better budgetary procedures is that they help ensure that fiscal rules are observed and the temptation to meet them through fiscal gimmickry reduced.

43. According to the OECD's Budgeting Practices and Procedures Database, performance against targets was not made publicly available in Belgium, the Czech Republic, Germany, Hungary and Luxembourg. However, some such information would be available from the European Commission.

44. While multi-year budgeting has accompanied improved performance in countries such as the Netherlands, in others, such as Italy, marked improvements have been less apparent (Maré, 2001).

45. For example, cross-country differences in reporting as documented in the OECD's database on Budgetary Practices and Procedures are striking.

46. Such audit institutions could be responsible for financial, compliance and performance auditing or a combination of all three types of audit.

47. Differences in policy frameworks for reporting public-private partnerships across countries suggest that some countries could use best practice to guard against the temptation of engaging in such investment only as a means to evade budgetary restrictions (Araujo and Sutherland, 2010). 
ECO/WKP(2012)9

\section{Fiscal rules}

Fiscal rules can play a role in sustaining a fiscal consolidation, but may not be sufficient on their own to return debt to prudent levels. While fiscal rules are generally not explicitly linked to consolidation needs they may prevent slippage. An important rational for the adoption of fiscal rules is related to the reluctance of governments to commit to fiscal discipline and their ability to abandon announced plans before implementation. In this light, fiscal rules may help governments commit and allay the fears of financial markets.

Fiscal rules can set targets for budget balances, spending and less commonly taxation. While debt targets can provide a long-term anchor for fiscal policy the more commonly used fiscal rules for debt ceilings are relatively impotent until they become binding. There is no one-size fits all approach given different types of fiscal problems and the nature of the economy. Beyond their intended direct effect, rules also have a role to play in communicating with the public and as such should be relatively simple to perform this role. However, as fiscal policy is multi-dimensional and the pressures on fiscal policy change over time a single or even a set of simple fiscal rules is unlikely to be optimal at all times. For example, tensions affecting fiscal policy include respecting the inter-temporal budget constraint and long termsustainability, achieving short-term stabilisation, addressing distributional concerns and promoting allocative efficiency. More complex or state-dependent rules will be more difficult to enforce and communicate, while undermining accountability. There is unlikely to be an easy formula. As such, fiscal rules are difficult to design (Box 7.1).

In practice, multiple rules are often used and past empirical analysis found that countries using a suite of rules have managed to sustain fiscal consolidation more successfully than others relying on a single rule (Guichard et al., 2007, IMF, 2009). ${ }^{48}$ New econometric work finds that countries that have either spending or budget balance rules or a combination of the two are more likely to stabilise debt (Molnar, 2012). Budget balance rules tend to increase the duration of consolidation episodes leading to a protracted adjustment process. The findings also suggest that more comprehensive fiscal rules - that is the larger part of government activity and the larger number of government levels they cover inter alia - are more likely to help stabilise debt. However, causality can also run the other way, as governments that are more committed to debt stabilisation are more likely to adopt fiscal rules or more comprehensive fiscal rules. ${ }^{49}$

The effects of fiscal rules and combinations of them can be examined with macro-econometric scenarios using NiGEM (Barrel et al., 2011). Using scenarios to examine the effects of different types and combinations of fiscal rules stochastic simulations were used to show the effect of country-specific shocks to spending and debt on consolidation efforts. Fiscal rules that correct for deviations from either debt or deficit targets constrain adverse debt dynamics from developing relative to the baseline (Figure 8.1). Differences in the impact of fiscal rules across countries reflect differences in the country models and the different size of historical shocks to debt and deficits. Nonetheless, a rough hierarchy of the fiscal rules emerges in their ability to control debt dynamics. Fiscal rules based on deviations from deficit targets and often combinations of rules based on deficit targets and debt targets tend to have a greater impact than rules based solely on debt. The ranking reflects the history of shocks to debt and deficits that countries have experienced.

48. Furthermore, when pressures originate from sub-central governments, fiscal rules applied at the sub-central level may help a consolidation and meeting long-term sustainability objectives (Sutherland et al., 2005).

49. A standard criticism of such findings is that causality can also run the other direction, with governments more committed to debt stabilisation more likely to adopt fiscal rules. 


\section{Box 7.1. The design of fiscal rules}

Spending rules are often seen as attractive (Anderson and Minarik, 2006). Well-designed spending rules should be counter-cyclical, but since there is no inherent link with sustainability, setting the spending path presents difficulties. Setting the appropriate path requires information on the growth of potential output and future revenue over a business cycle. Thus, if the economy is hit by a significant supply shock fiscal policy will adapt only slowly to new circumstances unless buttressed by a budget balance rule that would force fiscal policy to react. Hauptmeier et al. (2010) suggest that for the euro area spending growth should be capped at potential GDP growth minus half a percentage point to correct for ex ante bias in growth forecasts.

Somewhat puzzlingly, empirical assessments of spending rules do not suggest that they constrain politicians from spending revenue windfalls during upswings (Hauptmeier et al., 2011). Instead, they appear to make spending less sensitive to output surprises during downturns (Wierts, 2008). There are two factors that may contribute to this: First, buoyant revenues during upswings are "spent" using tax expenditures. In this light, a spending rule is not immune to pro-cyclicality and requires careful monitoring of revenue-side developments. Second, some spending rules - for example, setting a ceiling on a spending ratio for the duration of a parliament - are not necessarily effective at constraining spending until the ceiling is close to being breached.

Budget balance rules are frequently used. Simple rules can be pro-cyclical, such as those applied in some states of the United States. Pro-cyclicality can be mitigated by building up precautionary cushions in so-called "rainy-day funds". In the case of rainy-day funds, there is an opportunity cost in withholding funds and if it leads to moral hazard it raises the associated risk of less prudent budgetary policy. An alternative approach is to introduce some flexibility into the rule, such as taking into account the cycle, though at the cost of more complexity and potential difficulties in monitoring that current policy is consistent with the budget objectives (Wyplosz, 2008). Specific forms of rules that permit greater flexibility, though not necessarily for cyclical reasons include:

- $\quad$ Debt brake rules that allow some flexibility and correct for deviations. Germany and Switzerland have clauses in their fiscal rules that impose corrective action if cumulative outturns exceed a threshold.

- $\quad$ The so-called golden rule, which allows governments to borrow for the purpose of investment, and thus help counter a tendency to myopia when budgets balances are bounded. Due to national accounts conventions, a golden rule may not solve the myopia problem completely, as investment-like spending, such as education, is classified within current spending. There may also be difficulties in defining investment.

Budget balance rules are also typically non-symmetric. The recent crisis saw renewed appetite for discretionary fiscal policy in many countries (Auerbach et al., 2010). If discretionary fiscal policy responds to future downturns to a greater extent, the desired degree of tightening during upswings may need to be greater to prevent a ratchet effect on government debt.

Debt-based rules may be appropriate when debt is an overriding concern. On the downside, debt rules are inherently pro-cyclical when they bite. When they are not binding they may be impotent unless buttressed by other fiscal objectives. As argued above, debt targets can serve to anchor fiscal policy and provide the basis for setting medium-term budget targets that can then be translated into annual spending or deficit targets. However, care is needed in the design so that slippage in attaining intermediate targets is corrected.

The design of fiscal rules may need to consider the circumstances when they no longer need apply and what measures are appropriate when they are breached. In the wake of the crisis virtually all OECD countries suspended their fiscal rules temporarily. To some extent the ad hoc nature of the decisions and the uncertainty about when and whether governments will again begin to respect the rules undermines their role as a commitment device. These are issues that would benefit from ex ante clarification to preserve the integrity of the rules. This would require specifying which conditions allow governments to suspend fiscal rules and thereby providing a safety valve as well as how and when to re-introduce the rule. Fiscal rules should also consider the appropriate action when the rule is breached. Such mechanisms are provided in the fiscal rules in Germany, Spain and Switzerland, and in the EU rules, while this role is played by the independent fiscal council in Sweden. The recently proposed rule in the European Union that requires consolidation in proportion to the gap between the debt overshoot and the debt threshold could be infeasible for countries with large gaps. The contractionary effect on output may require additional heavy contractions in subsequent years (Fioramani and Vicarelli, 2011). 
Figure 8.1. Impact of rules on debt stocks during consolidation

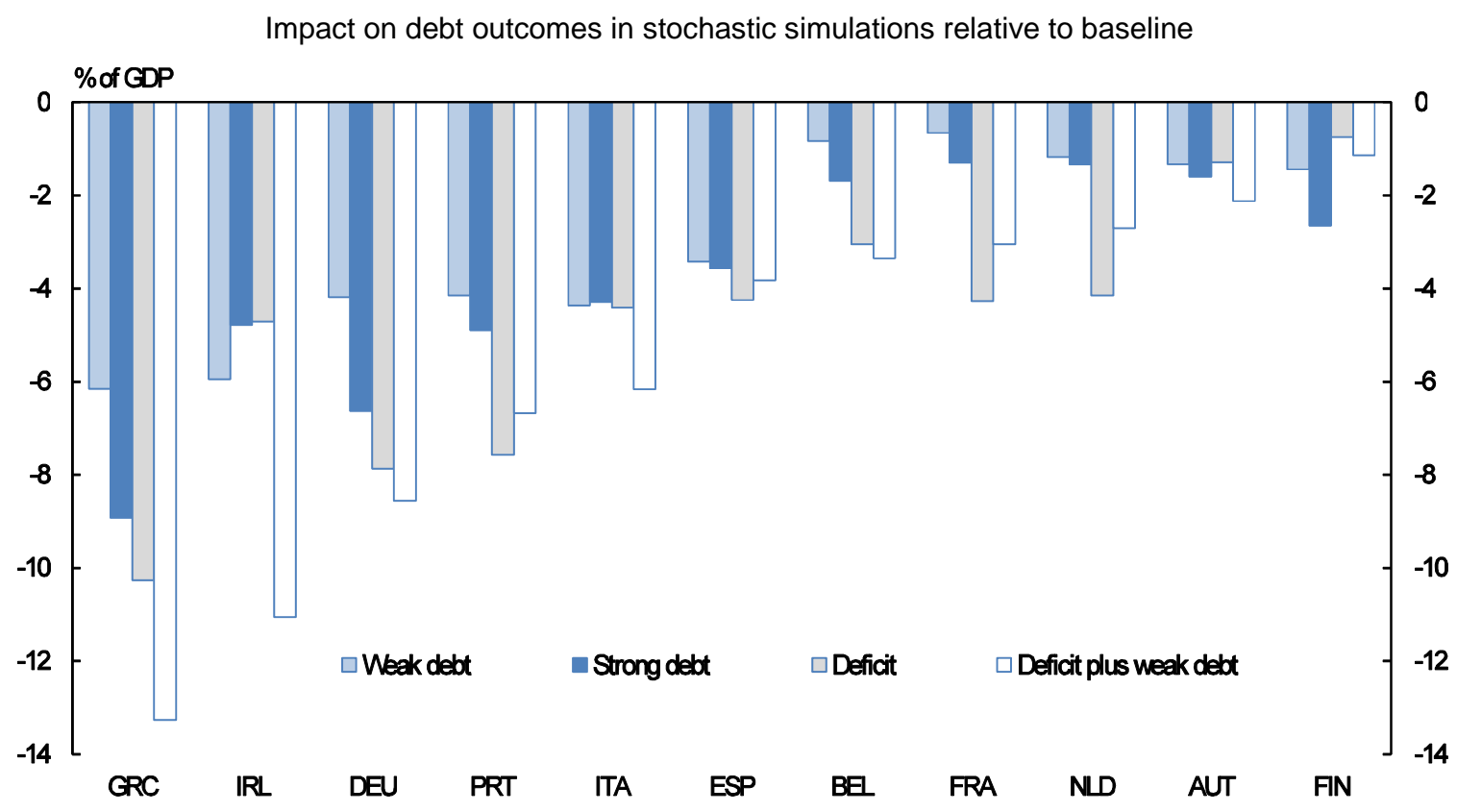

Note: The columns refer to different types of "fiscal rules". Weak debt refers to a rule that adjusts fiscal policy to deviations of debt from its target level. Strong debt is like weak debt, but forces a faster adjustment. Deficit is an adjustment in fiscal policy to deviations of deficits from deficit targets. The impact is for the upper part of the distribution (the 95th percentile) of the stochastic simulations relative to the same part of the distribution in the baseline simulations. The assumptions used in the simulations are financial markets are forward looking, consumers are myopic, all consolidation measures are permanent and monetary policy targets inflation and the stock of money.

Source: Barrell et al., 2012.

Notwithstanding the attraction of fiscal rules, they may create unwelcome side effects. For example, spending rules may affect allocative efficiency or attempts to restrain aggregate spending could lead to distortions in spending patterns as some programmes are less amenable to short-term discretionary control than others, such as reforms to unsustainable entitlement programmes. Instead, there may be an overemphasis on measures that have a high short-term payoff, but at the cost of weaker longer-term performance (Bacchiocchi et al., 2011). In addition, fiscal rules may encourage creative accounting. Creative accounting is less likely when the social cost of missing fiscal targets or when the probability of being discovered is high (for example, when fiscal transparency is high). A high probability of being discovered fosters genuine fiscal consolidation (Koen and van den Noord, 2005 and Milesi-Ferretti, 2000), supporting a role for enhanced transparency in budgetary procedures.

\section{Fiscal councils}

Fiscal councils have the potential to help a fiscal consolidation through their effect on fiscal performance and by taking a wider view on fiscal consolidation needs than a rule-based system is likely to do on its own. A fiscal council could contribute to improved fiscal performance in a number of ways (Hagemann, 2010). ${ }^{50}$ For example, by providing an independent view on fiscal policy, whether related to policy formulation, evaluation or monitoring, they can inform voters and other stakeholders more accurately when fiscal policy is off-track and raise the political costs of fiscal laxity. However, the creation

50. Independence need not be formal. In the Netherlands the CPB is attached to the ministry, but operates with considerable independence. 
of fiscal councils may simply be an expression of a political commitment to consolidation and without the development of credibility they may not affect performance once popular support for consolidation wanes.

Fiscal councils can complement fiscal rules by judging whether fiscal policy adheres to fiscal rules (Calmfors and Wren-Lewis, 2011). This was seen as a problem in the United Kingdom during the 2000s, where the Treasury had leeway in dating the business cycle, which would then determine whether fiscal policy was in compliance with the requirement of balancing the budget over the cycle. The mandate of the new Office of Budget Responsibility is specifically designed to remove such potential conflicts. In some cases, a fiscal council that has sufficient credibility could monitor the implementation of more complex fiscal rules, such as those targeting cyclically-adjusted or underlying balances, which would allow less simplistic fiscal rules to be implemented. Furthermore, an additional attraction with respect to fiscal rules would be for the fiscal council to assist politicians in deciding when a breach of rule was justified by economic conditions and possibly when governments should begin consolidating. ${ }^{51}$

A fiscal monitoring body could complement fiscal rules by having a mandate to comment explicitly on long-term sustainability of the public finances. In some cases, fiscal councils have such mandates, for example by providing long-term analyses (even though many governments already systematically perform these calculations). To be fully effective, the fiscal council may need to comment on whether current policies are consistent with meeting long-term objectives despite being consistent with medium-term objectives, if the latter are not explicitly linked to the long-term sustainability of the public finances.

Fiscal councils can perform tasks that may mitigate specific political economy problems. When a deficit bias arises from over-optimistic forecasting an independent fiscal council given this task can eliminate the source of deficit bias, though conservative forecasting assumptions in budgetary procedures can achieve a similar aim (Hagemann, 2010). Indeed, there appears to be a relationship between comparatively poor budget outcomes and systematic over-optimism: errors in budget balance forecasts are larger for countries running worse budget positions (Frankel, 2011) ${ }^{52}$ The mandate for the independent fiscal council in Belgium is to ensure that forecasts are independent and less subject to potential bias. However, while independent forecasting can help correct over-optimistic forecasting, deficit biases arising from other pathologies may be better addressed by other approaches such as cautious budget assumptions.

51. A more extreme variant is for a fiscal council to replace a fiscal rule. For example, Wyplosz (2005, 2008) proposed that a fiscal council should serve as a surrogate for a fiscal rule to overcome the difficulties associated with fiscal rule implementation such as determining the state of the cycle.

52. Cimadomo (2011) finds that numerical fiscal rules and fiscal institutions such as medium-term budgetary frameworks are associated with more accurate fiscal forecasts and data releases. 
ECO/WKP(2012)9

\section{Bibliography}

Adema, W., and M. Ladaique (2009) "How Expensive is the Welfare State? Gross and Net Indicators in the OECD Social Expenditure Database (SOCX)", OECD Social, Employment and Migration Working Papers, No. 92.

Ahrend, R., P. Catte and R. Price (2006), "Interactions Between Monetary and Fiscal Policy: How Monetary Conditions Affect Fiscal Consolidation", OECD Economics Department Working Paper, No. 521.

Aiyagari, R.S. and E.R. McGrattan (1998), "The Optimum Quantity of Debt", Journal of Monetary Economics, Vol. 42.

Anderson, B. and J. Minarik (2006), "Design Choices for Fiscal Policy Rules", OECD Journal of Budgeting, Vol. 5, No. 4.

Antolin, P., A. de Serres and C. Maisonneuve (2004), "Long-Term Budgetary Implications of TaxFavoured Retirement Plans", OECD Economics Department Working Paper, No. 393.

Araujo, S. and D. Sutherland (2010), "Public-private Partnerships and Investment in Infrastructure", OECD Economics Department Working Paper, No. 803.

Atkinson, A. and J. Stiglitz (1976), "The Design of Tax Structure: Direct Versus Indirect Taxation", Journal of Public Economics, Vol. 6.

Auerbach, A. (1994), "The U.S. Fiscal Problem: Where We Are, How We Got Here, and Where We're Going”, in S. Fischer and J. Rotemberg (eds.), NBER Macroeconomics Annual, National Bureau of Economic Research.

Auerbach, A. and Y. Gorodnichenko (2010), "Measuring the Output Responses to Fiscal Policy", NBER Working Paper, No. 16311.

Auerbach, A., W. Gale and B. Harris (2010), “Activist Fiscal Policy”, Journal of Economic Perspectives, Vol. 24, No. 4.

Bacchiocchi, E., E. Borghi and A. Missale (2011), "Public Investment under Fiscal Constraints", Fiscal Studies, Vol. 32, No. 1.

Barbier-Gauchard, A., A. Guilloux, and M. Le Guilly (2010), “Tableau de bord de l'emploi public”, Centre d'analyse stratégique, French Prime Minister's Office.

Barrell, R., D. Holland and I. Hurst (2012), "Fiscal Consolidation: Part 4. Fiscal Multipliers and Fiscal Consolidation", OECD Economics Department Working Paper, No. 933.

Barro, R.J. (1979), "On the Determination of the Public Debt", Journal of Political Economy, Vol. 87, No. 5. 
Bassanini, A. and R. Duval (2006), "Employment Patterns in OECD Countries: Reassessing the Role of Policies and Institutions", OECD Economics Department Working Paper, No. 486.

Bernanke, B. (2005), "The Global Saving Glut and the U.S. Current Account Deficit”, Remarks by Governor Ben S. Bernanke at the Sandridge lecture, Virginia Association of Economists, Richmond, Virginia, March 10.

Blanchard, O. (1990), "Suggestions for a New Set of Fiscal Indicators", OECD Economics Department Working Paper, No. 79.

Blanchard, O. and J. Wolfers (2000), "The Role of Shocks and Institutions in the Rise of European Unemployment: The Aggregate Evidence”, Economic Journal, Vol. 110, No. 462.

Blöchliger, H., D.H. Song and Douglas Sutherland (2012), "Fiscal Consolidation: Part 4. Case Studies of Large Fiscal Consolidation Episodes", OECD Economics Department Working Paper, No. 935.

Blöndal, S., S. Field and N. Girouard (2002), "Investment in Human Capital through Post-compulsory Education and Training: Selected Efficiency Aspects", OECD Economics Department Working Paper, No. 333.

Blume, L. and S. Voigt (2011), "Does Organizational Design of Supreme Audit Institutions Matter?", European Journal of Political Economy, Vol. 27, No. 2.

Bouis, R. and R. Duval (2011), "Raising Potential Growth after the Cycle: A Quantitative Assessment of the Potential Gains from Various Structural Reforms in the OECD Area and Beyond", OECD Economics Department Working Paper, No. 835.

Calmfors, L. and S. Wren-Lewis (2011), "What Should Fiscal Councils Do?", Oxford Discussion Paper, No. 537.

Caner, M., T. Grennes and F. Koehler-Geib (2010), "Finding the Tipping Point - When Sovereign Debt Turns Bad”, World Bank Policy Research Working Paper, No. 5391.

Castro, F. de, J. Pérez and M. Rodríguez (2011), "Fiscal Data Revisions in Europe", Banco de Espana Working Paper, No. 1106.

CBO (2004), Measures of the U.S. Government's Fiscal Position under Current Law, Congressional Budget Office, Washington, D.C.

CBO (2011a), 2011 Long-term Budget Outlook, Congressional Budget Office, Washington, D.C.

CBO (2011b), Reducing the deficit: Spending and Revenue Options, Congressional Budget Office, Washington, D.C.

Cecchetti, S., M. Mohanty and F. Zampolli (2011), "The Real Effects of Debt", BIS Working Paper, No. 352.

Checherita, C. and P. Rother (2010), "The Impact of High and Growing Government Debt on Economic Growth. An Empirical Investigation for the Euro Area", ECB Working Paper, No. 1237.

Christiano, L., M. Eichenbaum and S. Rebelo (2009), "When is the Government Spending Multiplier Large?", NBER Working Paper, No. 15394.

Cimadomo, J. (2011), "Real-time Data and Fiscal Policy Analysis: A Survey of the Literature", Federal Reserve Bank of Philadelphia, Research Department Working Paper, No. 11-25. 
Clinton, K., M. Kumhof, D. Laxton and S. Mursula (2010), "Budget Consolidation: Short-term Pain and Long-term Gain,” IMF Working Paper, No. 10/163.

Cogan, J., T. Cwik, J. Taylor and V. Wieland (2009), "New Keynesian versus Old Keynesian Government Spending Multipliers", ECB Working Paper, No. 1090.

Commonwealth of Australia (2010), Australia's Future Tax System, Report to the Treasurer, Part 1 and 2, December, http://taxreview.treasury.gov.au/content/Content.aspx?doc=html/home.htm.

Congressional Budget Office (2010), The Long-term Budget Outlook, A CBO Report, June.

Congressional Budget Office (2011), Reducing the Deficit: Spending and Revenue Options, Washington, D.C.

Congressional Research Service (2008), Tax Expenditures: Compendium of Background Material on Individual Provisions, 110th Cong., 2d Session, Print \#667, December,

http://taxprof.typepad.com/taxprof_blog/2009/02/tax-expenditures-compendium-of-backgroundmaterial-on-individual-provisions.html

Corden, M. (2009), "The Theory of Fiscal Stimulus: How will a Debt-financed Stimulus Affect the Future?", CEPR Policy Insight, No. 34.

Corsetti, G., K. Kuester, A. Meier and G. Muller (2010), "Deep Consolidation and Fiscal Stabilization of Deep Recessions", American Economic Review, Vol. 100.

Corsetti, G., K. Kuester, A. Meier and G. Muller (2011), "Sovereign Risks and the Effects of Fiscal Retrenchments in Deep Recessions", Federal Reserve Bank of Philadelphia Research Department Working Paper, No. 11-43.

Cournède, B. (2007), "The Political Economy of Delaying Fiscal Consolidation”, OECD Economics Department Working Paper, No. 548.

Duval, R. (2003), "The Retirement Effects of Old-Age Pension and Early Retirement Schemes in OECD Countries", OECD Economics Department Working Paper, No. 370.

Égert, B. (2010), “Fiscal Policy Reaction to the Cycle in the OECD: Pro- or Counter-cyclical?", OECD Economics Department Working Paper, No. 763.

Erceg, C. and J. Linde (2010), "Is There a Fiscal Free Lunch in a Liquidity Trap?", CEPR Discussion Paper, No. 7624.

Feldstein, M., D. Feenberg and M. MacGuineas (2011), "Capping Individual Tax Expenditure Benefits", NBER Working Paper, No. 16921, National Bureau of Economic Research.

Fioramanti, M. and C. Vicarelli (2011), "The New Stability and Growth Pact: Primum non Nocere", CEPS Working Document, No. 344.

Frankel, J. (2011), "Over-optimism in Forecasts by Official Budget Agencies and Its Implications", NBER Working Paper, No. 17239.

Giavazzi, F. and M. Pagano (1990), "Can Severe Fiscal Contractions Be Expansionary? Tales of Two Small European Countries", NBER Macroeconomics Annual, MIT Press, Cambridge.

Gonand, F., I. Joumard and R. Price (2007), "Public Spending Efficiency: Institutional Indicators in Primary and Secondary Education”, OECD Economics Department Working Paper, No. 543. 
Gruber, J. and S. Kamin (2010), "Fiscal Positions and Government Bond Yields in OECD Countries", Board of Governors of the Federal Reserve System International Finance Discussion Paper, No. 1011.

Guajardo, J., D. Leigh and A. Pescatori (2011), "Expansionary Austerity: New International Evidence", IMF Working Paper, No. WP/11/158.

Guichard, S., M. Kennedy, E. Wurzel and C. André (2007), "What Promotes Fiscal Consolidation: OECD Country Experiences", OECD Economics Department Working Paper, No. 553.

Hagemann, R. (2010), "Improving Fiscal Performance through Fiscal Councils", OECD Economics Department Working Paper, No. 829.

Hagemann, R. (2012), "Fiscal Consolidation: Part 6. What Are the Best Policy Instruments for Fiscal Consolidation?”, OECD Economics Department Working Paper, No. 937.

Hagen, J. von (1992), "Budgeting Procedures and Fiscal Performance in the European Communities", Commission of the European Communities Economic Paper, No. 96.

Hallerberg, M., R. Strauch, and J. Von Hagen (2004), "The Design of Fiscal Rules and Forms of Governance in the European Union Countries”, ECB Working Paper, No. 419.

Haugh, D., P. Ollivaud and D. Turner (2009), "What Drives Sovereign Risk Premiums? An Analysis of Recent Evidence from the Euro Area", OECD Economics Department Working Paper, No. 718.

Hauptmeier, S., J. Sanchez and L. Schuknecht (2011), "Towards Expenditure Rules and Fiscal Sanity in the Euro Area", Journal of Policy Modelling, Vol. 33.

Hernandez de Cos, P. and E. Moral-Benito (2011), "Endogenous Fiscal Consolidations”, Banco de Espana Working Paper, No. 1102.

HM Treasury (2011), Whole of Government Accounts: Unaudited Summary Report for the Year Ended 31 March 2010, HM Treasury, London.

Ilzetzki, E., E. Mendoza and C. Végh, (2009), "How Big are Fiscal Multipliers?”, CEPR Policy Insight, No. 39.

International Monetary Fund (2009), Fiscal Rules - Anchoring Expectations for Sustainable Public Finances, Washington, D.C.

International Monetary Fund (2010), World Economic Outlook, Washington, D.C.

Johansson, A, C. Heady, J. Arnold, B. Brys and L. Vartia (2008), "Taxation and Economic Growth", OECD Economics Department Working Paper, No. 620.

Jonung, L. (2010), "Lessons from the Nordic Financial Crisis", paper prepared for the AEA meeting in Denver.

Joumard, I., C. André and C. Nicq (2010a), "Health Care Systems: Efficiency and Institutions", OECD Economics Department Working Paper, No. 769.

Joumard, I., P. Hoeller, C. André and C. Nicq (2010b), Health Care Systems: Efficiency and Policy Settings, OECD Publishing. 
Joumard, I. and M. Pisu (2012), "Less Income Inequality and More Growth - Are they Compatible?

Part 3. Income Redistribution via Taxes and Transfers across OECD countries", OECD Economics Department Working Paper, No. 926.

Kirsanova, T. and S. Wren-Lewis (2007), "Optimal Fiscal Feedback and Debt in an Economy with Nominal Rigidities", Federal Reserve Bank of Atlanta Working Paper, No. 2007-26.

Koen, V. and P. van den Noord (2005), "Fiscal Gimmickry in Europe: One-off Measures and Creative Accounting", OECD Economic Department Working Paper, No. 417.

Kumar, M.S. and J. Woo (2010), "Public Debt and Growth”, IMF Working Paper, WP/10/174.

Laeven, L. and F. Valencia (2010), "Systemic Banking Crises: The New and the Old, the Good and the Ugly", IMF Working Papers, forthcoming.

Larch, M., and A. Turrini (2008), "Received Wisdom and Beyond: Lessons from Fiscal Consolidation in the EU”, European Economy Economic Papers, No. 320.

Laubach, T. (2003), "New Evidence on the Interest Rate Effects of Budget Deficits and Debt", FEDS Working Paper, No. 2003-12.

Lucas, R. and N. Stokey (1983), "Optimal Fiscal and Monetary Policy in an Economy without Capital", Journal of Monetary Economics, Vol. 12, No. 1.

Maré, M. (2001), "Comments of Session III: Fiscal Rules and Budgetary Procedures", in: Fiscal Rules, Banca d'Italia.

Merola, R., and D. Sutherland (2012), "Fiscal Consolidation: Part 3. Long-run Projections and Fiscal Gap Calculations", OECD Economics Department Working Paper, No. 934.

Milesi-Ferretti, G.M. (2000), "Good, Bad or Ugly? On the Effects of Fiscal Rules with Creative Accounting”, IMF Working Paper, WP/00/172.

Mirrlees Review (2010), Tax By Design, Institute for Fiscal Studies, Oxford University Press.

Molnar, M. (2012), "Fiscal Consolidation: Part 5. What Factors Determine the Success of Consolidation Efforts?", OECD Economics Department Working Paper, No. 936.

OECD (2003), Transforming Disability into Ability: Policies to Promote Work and Income Security for Disabled People, OECD Publishing.

OECD (2008), OECD Economic Outlook 84, OECD Publishing.

OECD (2009), Employment Outlook 2009, OECD Publishing.

OECD (2010a), OECD Economic Outlook 88, OECD Publishing.

OECD (2010b), Making Reform Happen, OECD Publishing.

OECD (2010c), Health at a Glance 2010, OECD Publishing.

OECD (2010d), "Health Care Systems: Getting More Value for Money", OECD Economics Department Policy Notes, No. 2. 
OECD (2010e), Choosing a Broad Base - Low Rate Approach to Taxation, Tax Policy Study No. 19, OECD Publishing.

OECD (2010f), Going for Growth, OECD Publishing.

OECD (2011a), Pensions at a Glance: Retirement Systems in OECD and G20 Countries, OECD Publishing.

OECD (2011b), Doing Better for Families, OECD Publishing.

OECD (2011c), “Tax Policy Reform and Fiscal Consolidation”, Tax Policy Brief, OECD Publishing.

OECD (2011d), Going for Growth 2011, OECD Publishing.

OECD (2011e), OECD Economic Outlook 89, OECD Publishing.

Ostry, J., A. Ghosh, J. Kim and M. Qureshi (2010), "Fiscal Space", IMF Staff Position Note, No. SPN/10/11.

Paesani, P., R. Strauch and M. Kremer (2006), "Public Debt and Long-term Interest Rates: The Case of Germany, Italy and the USA", ECB Working Paper, No. 656.

Price, R. and T. Dang (2011), "Adjusting Fiscal Balances for Asset Price Cycles", OECD Economics Department Working Paper, No. 868.

Ramsey, F. (1927), “A Contribution to the Theory of Taxation”, Economic Journal, 37(145).

Reinhart, C.M. and K.S. Rogoff (2010), "Growth in a Time of Debt", American Economic Review, Vol. 100, No. 2.

Röhn, O. (2010), "New Evidence on the Private Saving Offset and Ricardian Equivalence", OECD Economics Department Working Paper, No. 762.

Serres, A. de, F. Murtin and G. Nicoletti (2010), "A Framework for Assessing Green Growth Policies", OECD Economics Department Working Paper, No. 774.

Sutherland, D., R. Price and I. Joumard (2005), "Fiscal Rules for Sub-central Governments: Design and Impact", OECD Economics Department Working Paper, No. 465.

Sutherland, D., R. Price, I. Joumard and C. Nicq (2007), "Performance and Indicators for Public Spending Efficiency in Primary and Secondary Education", OECD Economics Department Working Paper, No. 546.

Sutherland, D., P. Hoeller, B. Égert and O. Röhn (2010), “Counter-cyclical Economic Policy”, OECD Economics Department Working Paper, No. 760.

Vogel, L. (2007), "How Do the OECD Growth Projections for the G7 Economies Perform? A PostMortem”, OECD Economics Department Working Paper, No. 573.

Whiteford, P. (2009), "Transfer Issues and Directions for Reform: Australian Transfer Policy in Comparative Perspective", Paper presented at the Australia's Future Tax and Transfer Policy Conference, Department of the Treasury and Melbourne Institute of Applied Economic and Social Research, Melbourne 18-19 June. 
ECO/WKP(2012)9

Wierts, P. (2008), “How do Expenditure Rules Affect Fiscal Behaviour?”, De Nederlandsche Bank Working Paper, No. 166.

Woodford, M. (1990), "Public Debt as Private Liquidity”, American Economic Review, Vol. 80, No. 2.

Woodford, M. (2010), "Simple Analytics of the Government Expenditure Multiplier", NBER Working Paper, No. 15714.

Wyplosz, C. (2005), "Fiscal Policy: Institutions versus Rules", National Institute Economic Review, No. 191.

Wyplosz, C. (2008), "Fiscal Policy Councils: Unlovable or Just Unloved?", Swedish Economic Policy Review, Vol. 15. 


\section{WORKING PAPERS}

The full series of Economics Department Working Papers can be consulted at www.oecd.org/eco/workingpapers/

931. Less income inequality and more growth - Are they compatible?

Part 8. The drivers of labour income inequality $-A$ review of the recent literature

(January 2012) by Rafal Kierzenkowski and Isabell Koske

930. Less income inequality and more growth-Are they compatible?

Part 7. The drivers of labour earnings inequality - An analysis based on conditional and unconditional quantile regressions

(January 2012) by Jean-Marc Fournier and Isabell Koske

929. Less income inequality and more growth-Are they compatible?

Part 6. The distribution of wealth

(January 2012) by Kaja Bonesmo Fredriksen

928. Less income inequality and more growth-Are they compatible?

Part 5. Poverty in OECD countries

(January 2012) by Mauro Pisu

927. Less income inequality and more growth-Are they compatible?

Part 4. Top incomes

(January 2012) by Peter Hoeller

926. Less income inequality and more growth-Are they compatible?

Part 3. Income redistribution via taxes and transfers across OECD countries

(January 2012) by Isabelle Joumard, Mauro Pisu and Debbie Bloch

925. Less income inequality and more growth-Are they compatible?

Part 2. The distribution of labour income

(January 2012) by Isabell Koske, Jean-Marc Fournier and Isabelle Wanner

924. Less income inequality and more growth-Are they compatible?

Part 1. Mapping income inequality across the OECD

(January 2012) by Peter Hoeller, Isabelle Joumard, Mauro Pisu and Debbie Bloch

923. Current issues in managing government debt and assets

(December 2011) by Eckhard Wurzel and Lukasz Rawdanowicz

922. Public spending efficiency in the Czech Republic: fiscal policy framework and the main spending areas of pensions and healthcare

(December 2011) by Zuzana Smidova

921. Exploring determinants of subjective wellbeing in OECD countries - evidence from the World Value Survey

(December 2011) by Sarah Fleche, Conal Smith and Piritta Sorsa

920. Russia: progress in structural reform and framework conditions

(December 2011) by Yana Vaziakova, Geoff Barnard and Tatiana Lysenko 
919. Explaining the interest-rate-growth differential underlying government debt dynamics (December 2011) by David Turner and Francesca Spinelli

918. Reassessing the NAIRUs after the crisis

(December 2011) by Stéphanie Guichard and Elena Rusticelli

917. Employment protection legislation and plant-level productivity in India

(December 2011) by Sean Dougherty, Verónica Frisancho Robles and Kala Krishna

916. Systemically important banks and capital regulation challenge

(December 2011) by Patrick Slovik

915. Improving educational outcomes in Slovenia

(December 2011) by Mehmet Eris

914. Addressing challenges in the energy sector in Israel

(December 2011) by Philip Hemmings

913. Issues in private sector finance in Israel

(December 2011) by Philip Hemmings

912. How to improve the economic policy framework for the housing market in Israel

(December 2011) by Philip Hemmings

911. Fiscal Prospects and Reforms in India

(December 2011) by Richard Herd, Sam Hill and Vincent Koen

910. Structural reforms to reduce unemployment and restore competitiveness in Ireland

(December 2011) by Álvaro Pina

909. Getting back on track: restoring fiscal sustainability in Ireland

(December 2011) by David Haugh

908. A welfare analysis of climate change mitigation policies

(November 2011) by Alain de Serres and Fabrice Murtin

907. Overcoming the banking crisis in Ireland

(November 2011) by Muge Adalet McGowan

906. Macroeconomic and structural policies to further stabilise the Mexican economy

(November 2011) by Cyrille Schwellnus

905. Reaping the benefits of a transition to greener growth in Slovakia

(November 2011) by Caroline Klein

904. Fiscal reform for a stronger fairer and cleaner Mexican economy

(October 2011) by Nicola Brandt and Rodrigo Paillacar

903. The demand for safe assets in emerging economies and global unbalances: new empirical evidence (October 2011) by Rudiger Ahrend and Cyrille Schwellnus 